Intergenerational association between birth weight and cardiovascular disease; a population-based study of offspring, their parents, aunts and uncles

Fareeha Shaikh

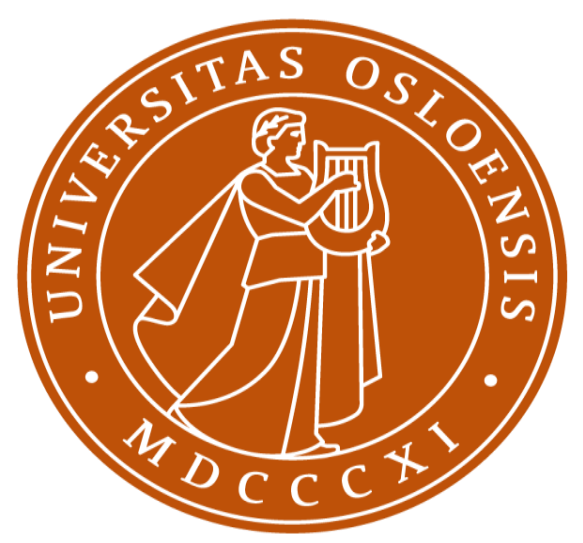

Department of Community Medicine and Global Health Institute of Health and Society

Faculty of Medicine

University of Oslo

2020 
(C) Fareeha Shaikh, 2020

Series of dissertations submitted to the Faculty of Medicine, University of Oslo

ISBN 978-82-8377-578-4

All rights reserved. No part of this publication may be reproduced or transmitted, in any form or by any means, without permission.

Cover: Hanne Baadsgaard Utigard.

Print production: Reprosentralen, University of Oslo. 


\section{Table of Contents}

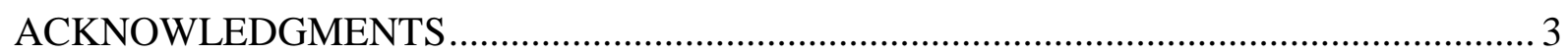

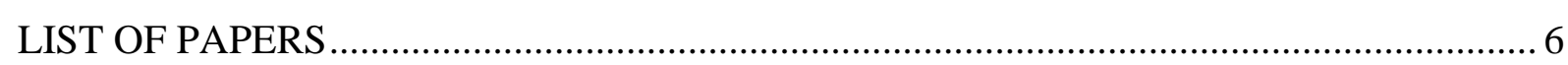

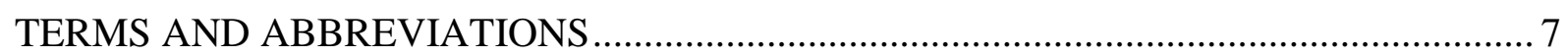

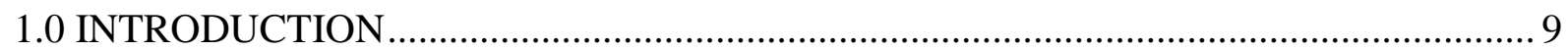

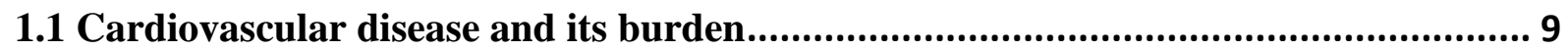

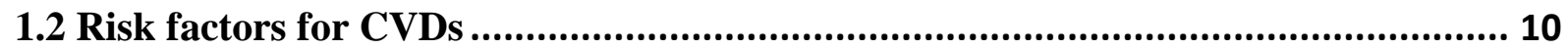

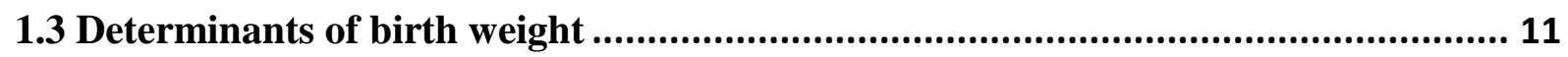

1.4 Association between low birth weight and increased risk of CVD later in life ......... 13

1.5 Mechanisms proposed to explain the association between birth weight and CVD ... 14

1.5.1 The thrifty phenotype or fetal programming hypothesis ...................................... 14

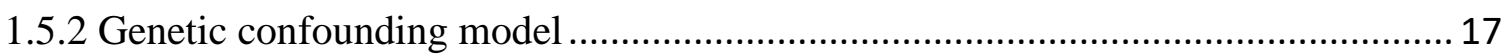

1.5.3 Socioeconomic and environmental confounding model ..................................... 18

1.6 Family-based studies (to investigate the role of shared genetic and environmental

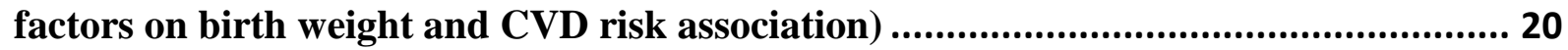

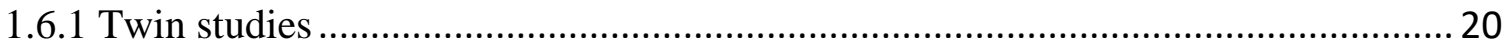

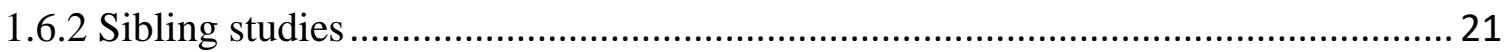

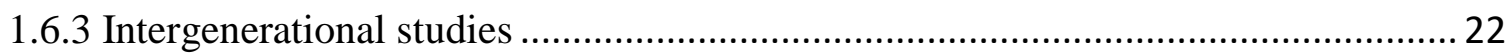

2.0 RATIONALE, AIM AND SPECIFIC OBJECTIVES OF THE STUDY ......................... 25

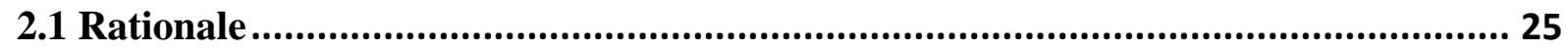

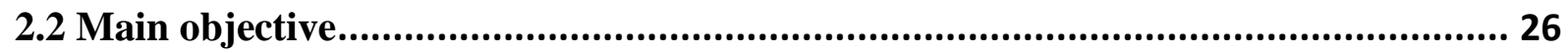

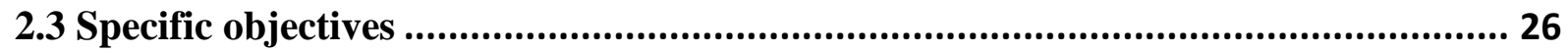

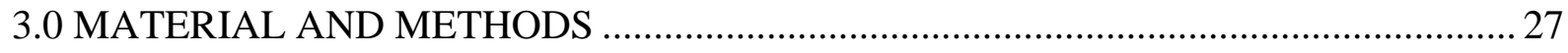

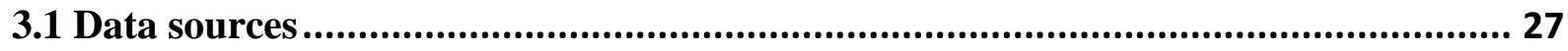

3.1.1 Medical Birth Registry of Norway (MBRN) (Paper I, II, III) ............................... 27

3.1.2 Cause of Death Registry (Paper I, II) ............................................................... 27

3.1.3 The National Education Database (NUDB) (Paper I, II, III) ................................ 28

3.1.4 The Cohort of Norway (CONOR) (Paper I, II, III) .................................................. 28

3.1.5 The Age 40 Program (1985-99) (Paper I, II, III) ................................................... 28

3.1.5 The Norwegian County Study (1974-88) (Paper I, II, III) ..................................... 28

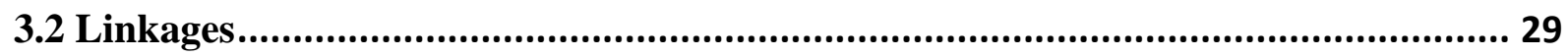

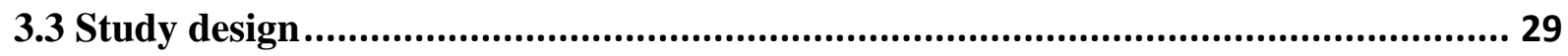

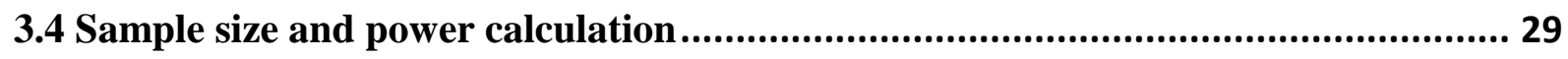

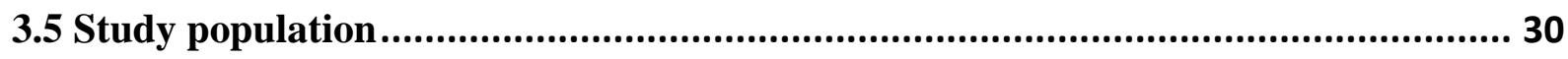


3.5.1 Paper I

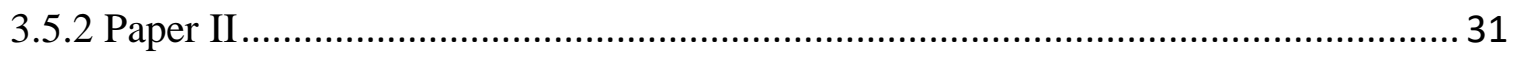

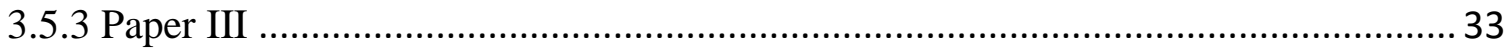

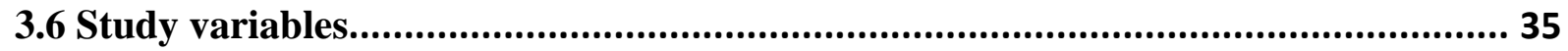

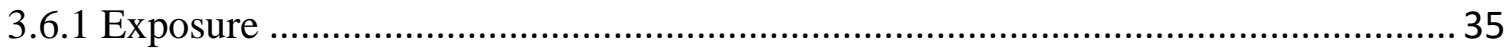

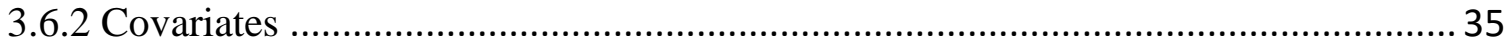

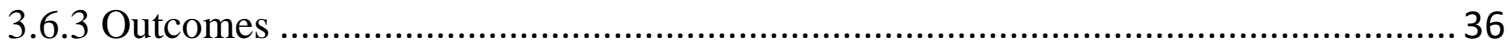

3.7 Statistical Methods........................................................................................... 36

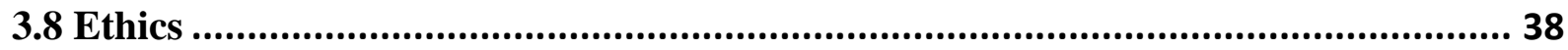

3.9 Overview of the included papers in the thesis ......................................................... 39

4.0 SUMMARY OF THE MAIN RESULTS ………………........................................... 41

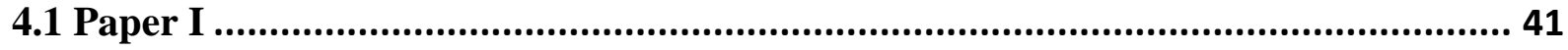

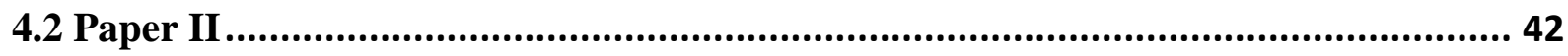

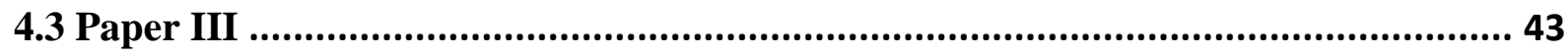

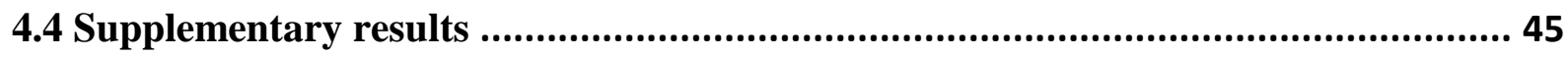

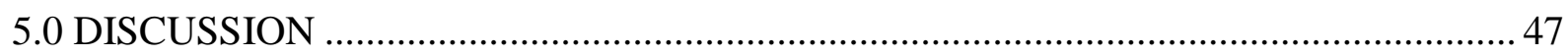

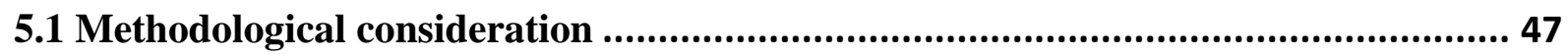

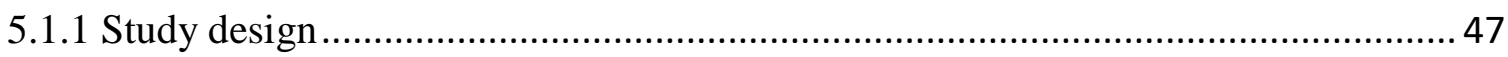

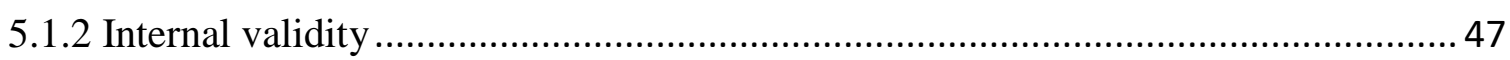

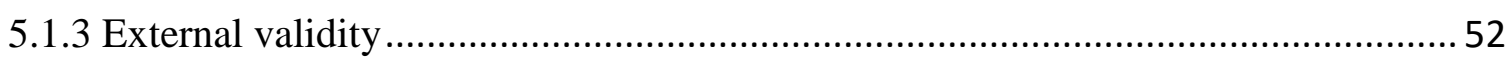

5.2 Discussion of main findings............................................................................. 52

5.2.1 Association between offspring birth weight and CVD risk in parents .................... 53

5.2.2 Associations between offspring birth weight and CVD risk in extended family members (aunts/uncles and their partners) ................................................................... 55

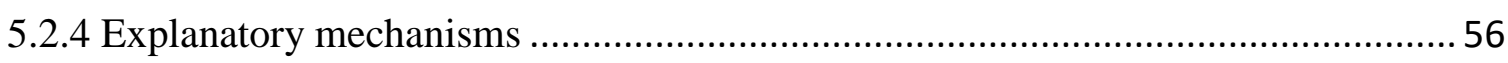

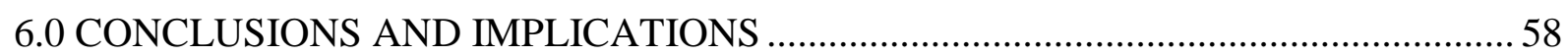

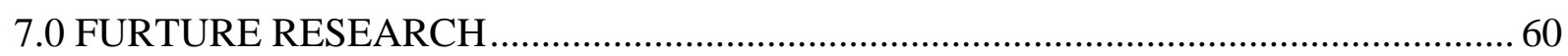

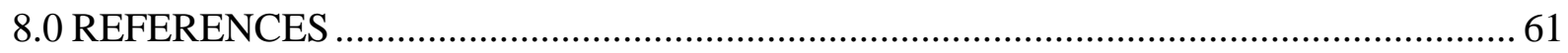

\section{PAPERS I-III}

APPENDIX 


\section{ACKNOWLEDGMENTS}

This work was done at the Department of Community Medicine and Global Health, Institute of Health and Society, Faculty of Medicine, University of Oslo. A number of people have contributed to this work and it would never have been possible without their cooperation. Funding was provided by the University of Oslo and ethical approval was attained by the Regional Ethics Committee of South-Eastern Norway.

I would like to express my heartfelt gratitude to my supervisor Øyvind Næss for his valuable guidance, encouragement and support during my study period. I really appreciate that you have introduced me to the family linkages and registry data. You have shared your great knowledge and provided immense moral support during this period. I also owe my sincere gratitude to my co-supervisors Marte Karoline Kjøllesdal for her valuable support and guidance throughout my study period and Magne Thoreson for his positive response and guidance in the project. This work could not have been done without your help and support.

I am thankful to the Institute of Health and Society, Faculty of Medicine, University of Oslo for the opportunity and financial support that has enabled me to take up this $\mathrm{PhD}$. I have enjoyed working with a group of bright and intelligent academics at the Department of Community Medicine and Global Health and all of the administrative staff at the institute that has given me invaluable input and a great environment to work.

I would like to give special thanks to all co-authors of my papers. Their valuable contributions during paper writing have increased the quality of the included papers. David Carslake, thank you for your extra thoughtfulness with detailed and constructive feedback that has greatly increased the quality of my articles.

I also like to thank my colleagues at HELSAM, especially Maria who taught me a lot about using STATA in the beginning of my work. Soheir, Lanzi, Thuzar, Wai Phyo, Eirik and Stine, you all were a kind support system during my study period. Furthermore, I would like to thank my friends here in Oslo and in Pakistan for their well wishes towards me. Fatima, I will forever value your kindness, encouragement and positive thinking about me. Line Løw and Vibeke Christie, I am truly grateful for your kind support, cooperation and sincere suggestions not only during but even before the start of this PhD. I feel more than this for both of you.

I also thank EPINOR, the National Research School in Population-based Epidemiology, for giving me chance to attend courses and conferences. 
Finally, special thanks to my family. Maa, sisters and brothers, thanks for your continuous encouragement and cooperation to pursue my education. Especially, the many words of wisdom and trust from my mother and sisters have helped me to always look forward and finish this work. Khurmi and Toto, you both are a source of strength for me. Bibi and Sahi, your witty conversations and encouragement always diluted the situation, whenever I called you in stress. Love you all! 
This work is dedicated to my dearest Ammi and Papa (late). 


\section{LIST OF PAPERS}

Offspring birth weight and cardiovascular mortality among parents: the role of cardiovascular risk factors

Fareeha Shaikh F, Marte Karoline Kjøllesdal MK, Øyvind Naess

Journal of Developmental Origins of Health and Disease 2018;

doi: $10.1017 / S 2040174418000065$

Birth weight in offspring and cardiovascular mortality in their parents, aunts and uncles: a family-based cohort study of 1.35 million births

Fareeha Shaikh, Marte Karoline Kjøllesdal, David Carslake, Camilla Stoltenberg, George Davey Smith, Øyvind Næss

International Journal of Epidemiology, 2019; doi: 10.1093/ije/dyz156

Cardiovascular risk factors in extended family members and birth weight in offspring

Fareeha Shaikh, Marte Karoline Kjøllesdal, David Carslake, Magne Thoresen, Øyvind Næss (submitted) 
TERMS AND ABBREVIATIONS

AGA Appropriate for gestational age

AMI Acute myocardial infarction

BMI Body mass index

BW Birth weight

CHD Coronary heart disease

CONOR Cohort Norway

CVD Cardiovascular disease

DBP Diastolic blood pressure

DUB National Education Registry

DZ Dizygotic

GA Gestational age

GWAS Genome-wide association studies

HR Hazard ratio

IHD Ischemic heart disease

LBW Low birth weight

LGA Large for gestational age

MZ Monozygotic

MBRN Medical Birth Registry

RHR Resting heart rate

SGA Small for gestational age

SBP Systolic blood pressure

SES Socioeconomic status

TC Total cholesterol

TG Triglycerides

T2D Type 2 diabetes 


\section{PREFACE}

Cardiovascular diseases (CVDs) are the leading cause of death in the world. The burden of CVD is not expected to decrease in the near future and CVD will probably remain an important cause of mortality and morbidity among both men and women. To prevent CVD, it is of interest to identify people who have an increased risk at an early stage, both from a public and from a clinical perspective. A large body of evidence suggests that early-life experiences, such as intrauterine growth and development are associated with several chronic diseases, including CVD and diabetes, in adult life. However, explanatory pathways underlying these associations are not yet clearly understood. It has been suggested that shared environmental, genetic as well as intrauterine factors may be responsible for explaining these associations.

Low birth weight has been associated with later CVD in a number of studies. Most studies suggest a modest role of shared environmental factors within families in this association, whereas some evidence points towards common genetic factors to play a role. However, the data with respect to this association is sparse. The evidence regarding the role of genetic factors comes from epidemiological studies reporting an inverse association between offspring birth weight and CVD risk among their parents. Distinguishing between two potential mechanisms (genetic and environmental) underlying the association between fetal growth and later disease is clearly of considerable importance for understanding the aetiology and prevention of CVD.

Norwegian health registries are valuable in the context of research and can be used to study large cohorts with long follow-up times. Furthermore, Norwegian health surveys focusing on cardiovascular risk factors are also very valuable and unique in this context. They provide an opportunity to study the relationships between birth weight in offspring and risk of CVD in family members with different genetic relatedness. The unique personal identification numbers in Norway enable linkage between the different health registries.

In this population-based study, different Norwegian health registries (the Medical Birth Registry, the Cause of Death Registry, the Education Registry) and health surveys (County study, Age 40 Program, CONOR) were used to study the transgenerational association between offspring birth weight and risk of CVD in parents, aunts and uncles as well as partners of aunts and uncles. 


\subsection{INTRODUCTION}

\subsection{Cardiovascular disease and its burden}

Cardiovascular diseases (CVDs) are the leading cause of mortality and morbidity worldwide and carry a huge economic burden. [1] CVD includes coronary heart disease (CHD), cerebrovascular disease, heart failure and peripheral arterial disease. CHD, the most common form of CVD, is responsible for more than one third of CVD in the world. [2] In 2016, CVDs were responsible for 17.9 million deaths annually in the world. [3, 4] It has been expected that this number is going to increase to more than 23.6 million by 2030. [5] CVDs were the leading cause of deaths in Europe in 2015 (responsible for more than 4 million deaths per year), with Central and Eastern Europe having the highest prevalence rate. [6] Although the incidence of CVD is declining in high income countries, it has been increasing rapidly in low income countries. [3]

In Norway, the incidence of CVD has declined during the last two decades due to an overall lowering of risk factors in the population coupled with better treatment options. However, an aging population and better quality of life may result in more people living with CVD. The age-standardized mortality from myocardial infarction and other ischemic heart diseases (IHD) has declined in Norway from 1970 to 2016, with a greater decline among age group over 75 years compared to age group less than 75 years. (Figure 1) Despite this decline, it has been observed that hospitalization of young people with acute myocardial infarction (AMI) has increased by $11 \%$ from 2001 to 2009. [7] A recent report shows that around 40,000 people consulted physicians or receive specialized healthcare services for angina and myocardial infarction. However, the number of people with a diagnosis of stroke and heart failure were 11,000 and 16,000, respectively. [8] According to 2013 estimates, the number of men and women dying from CVD was 5,979 and 7,035 respectively. [8] Considering agestandardized data, CVD death rates are higher among men, compared to women. But the total number of deaths due to CVD is higher in women, as the total number of elderly women is higher than the corresponding number for elderly men. [9] 
Ischaemic heart disease, mortality

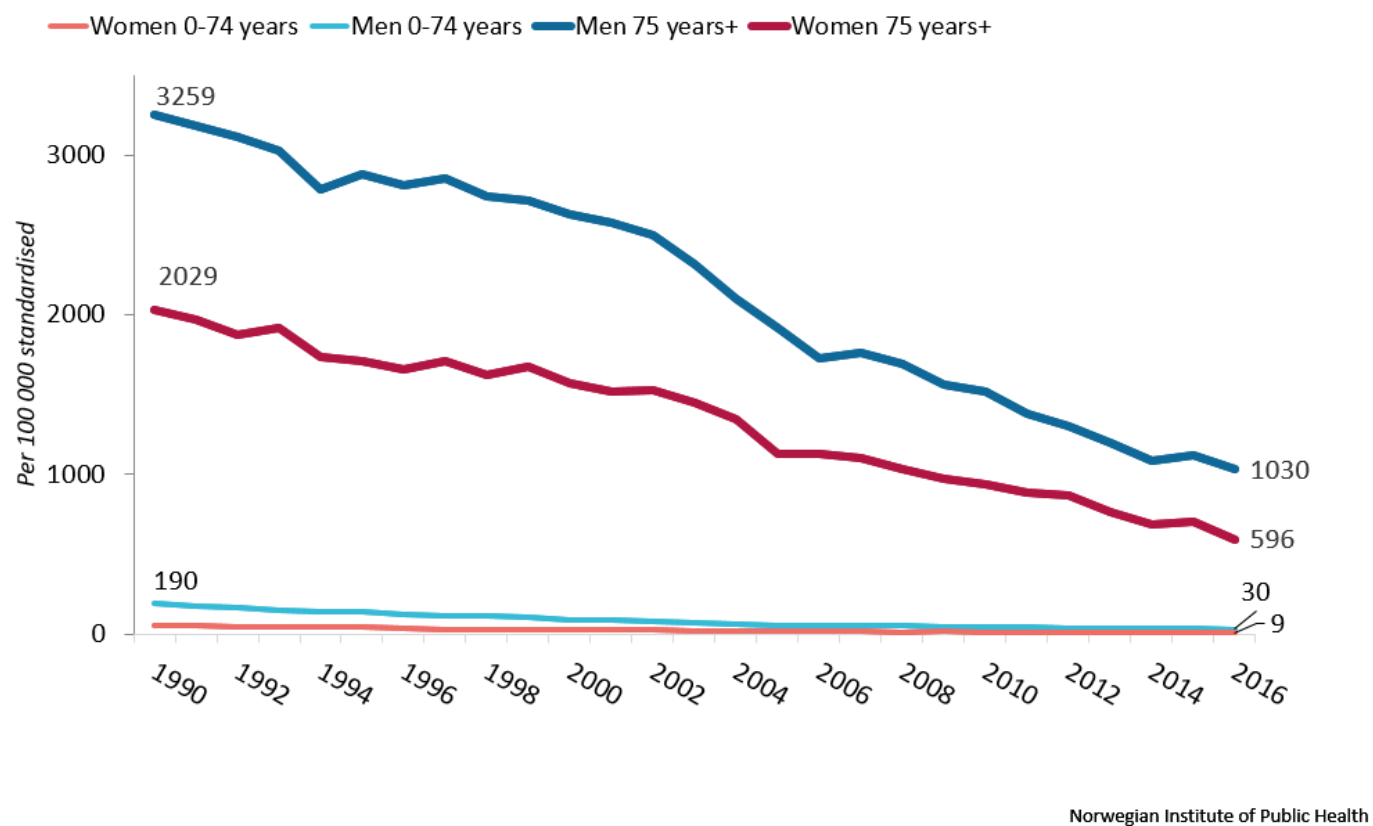

Figure 1: Age standardized rates of deaths from myocardial infarction and other ischemic heart diseases per 100,000 inhabitants per year for men and women.

\subsection{Risk factors for CVDs}

Increasing age, being male, impaired lipid profiles, smoking, hypertension, and diabetes are well-established risk factors for CVDs. It is estimated that these risk factors can predict 75$80 \%$ of the risk of CVD incidence in an individual. [10] Apart from age and sex, other CVD risk factors are, to a large extent, associated with lifestyle and influenced by individual behaviour. Unhealthy diet, tobacco use, low physical activity and alcohol consumption are the major behavioural risk factors for CVD. A number of multivariable risk models are used to estimate the risk of initial CVD events in apparently healthy, asymptomatic individuals, such as the Framingham risk score, QRISK3 and SCORE. Different risk factors are included in each model, and the most common factors included are age, gender, total cholesterol, systolic blood pressure, current smoking and diabetes mellitus. [11] In addition, family history of CVD and antihypertensive treatment are included in the Norwegian risk score model, NORRISK 2. [12] A large multicenter study (INTERHEART) of 52 countries reported that $90 \%$ of the risk of first myocardial infarction (MI) was accounted for by nine potentially modifiable risk factors; smoking, hypertension, abdominal obesity, diabetes, alcohol intake, abnormal lipids, no daily intake of fruit and vegetables, psychosocial factors and low physical activity. [13] In Sweden, reduction in blood cholesterol, blood pressure and smoking were 
found to be the main reasons for the decline in numbers of deaths from heart attacks between 1986 and 2002. [14]

In Norway, a decline in blood cholesterol and blood pressure has been reported since 1974. $[15,16]$ Between 1995 and 2015, the percentage of daily smokers in Norway decreased from $33 \%$ to 13\%. [17] Physical activity in Norway was found to have risen across all ages, but this increase was greater among older individuals, when compared with younger ones. [18] Despite this rise, an increasing trend for high body weight and diabetes has also been observed in the population. [8] Moreover, it has been reported that smoking, obesity and diabetes are major risk factors contributing to increasing incidence of coronary heart disease among women. [19-22]

Familial aggregation of CVD risk factors has been reported in a number of previous studies. [23-26] Parental weight gain and obesity was associated with high BMI and obesity in offspring in several studies. [27, 28] A few studies reported a stronger mother-offspring than father-offspring association for BMI, [29-31] whereas others have not. [32, 33] In addition, parent-offspring associations for blood lipids and blood pressure has been reported. [34, 35] This parent-offspring similarity in CVD risk factors can be explained by both genetic and environmental factors. [36] However, those who found stronger associations in mothers suggest that intrauterine factors could be more important. A recent study, reporting similar mother-offspring and father-offspring associations for blood pressure, lipids and, blood glucose, proposed that a specific maternal effect, due to intrauterine exposures, was weak for these risk factors. They suggested that genetic or environmental factors, shared between parents, were the main drivers for these parent-offspring associations. [37]

\subsection{Determinants of birth weight}

Birth weight is considered an important predictor for survival of newborns and infants, and is a significant indicator of pregnancy outcomes. Birth weight has been extensively studied in epidemiology, because it is accurately measurable and available for large populations. It has been considered a marker of intrauterine growth and environment and was found to be associated with subsequent health risks, not only in early life but also in adult life. [38]

Maternal biological factors such as gestational age (GA), weight, height and BMI [39] along with parity and sex (of a delivered child), [40] are main factors that can influence a child's birth weight. Socioeconomic factors, for instance maternal education and household income have also been considered important predicting factors for birth weight of offspring. [41] 
Studies have shown a strong association between birth weight of an infant and poor maternal nutrition (before and during pregnancy), [42] smoking and caffeine consumption in mothers. [43-45] Moreover, energy, fatty acids and micronutrient deficiencies have been implicated in causing low birth weight (LBW) in offspring. [46]

Intergenerational studies found a significant association between offspring birth weight with that of their mothers and fathers. [47, 48] The association with mothers' birth weight was found to be stronger compared to fathers'. These associations may be explained by genetic factors passed on from father and mother to the fetus, and by maternal genes acting on the mother's capability of carrying a pregnancy. Environmental factors that are shared among parents may also explain these associations. A correlation in birth weight has been observed also between half siblings of the same mother, but not of the same father. [49] This suggests that maternal genotype along with other maternal factors may have greater contribution in the association than paternal factors. In many populations, a mother has had a greater role in the childcare and children spend more time with their mothers. This factor could also be one of the reasons for the greater correlation in birth weight between half siblings of the same mother than those of the same father.

Studies have shown that in twins and in small for gestational age children a $25-40 \%$ variability in birth weight, gestational age and in fetal growth were caused by genetic factors. $[50,51]$ Other studies, trying to separate the effect of fetal and maternal genotype, reported that more than $50 \%$ of the variability in birth weight was primarily caused by fetal genotype and less than $10 \%$ was caused by maternal genotype. [52] They suggested that a remaining $30-40 \%$ of the variance could be explained by random environmental effects. Another study estimated that environmental influences account for about $25 \%$ and genetic influences account for $38-80 \%$ of variance in the birth weight. [53, 54] However, no definite effects were found of family-specific environment on interactions between fetal and maternal genes. [53]

Previous studies have also investigated the association between birth weight of offspring and physical characteristics of their aunts and uncles (both maternal and paternal). They found that only maternal aunts shared important links with offspring birth weight and suggested that genetic effects from mothers were more important than paternal genetic effects, and that fetal growth over generations was mainly dependent on maternal transmission. [55] Understanding 
the causes of variation in birth dimensions is important in relation to their impact on outcomes, in both the perinatal period and later life.

\subsection{Association between low birth weight and increased risk of CVD later in life}

An inverse association between birth weight and subsequent health outcomes such as type 2 diabetes (T2D) and CVD has been extensively reported in previous studies. The importance of early life circumstances on later disease risk was suggested back in the 1970s when Anders Forsdahl reported differences in the CVD mortality rates in different counties of Norway for the first time. [56] He suggested that this difference in CVD mortality might be related to poverty and deprivation in early life. Later on, Barker and his colleagues put forward Forsdahl's idea and reported a strong association between geographical areas, ischemic heart disease (IHD), and infant mortality. They found a high prevalence of mortality from IHD in the less affluent areas in different counties of England. [57] Afterwards, in a subsequent study, Barker reported an inverse association between birth weight and risk of coronary heart disease (CHD) in adulthood. [58] He suggested that adult CVD was associated with impaired fetal growth, which could be a manifestation of maternal and fetal malnutrition.

Barker, who first observed the association between birth weight and adult CVD risk, hypothesized that the fetus makes metabolic adaptations in a compromised intrauterine environment (undernourished), and that these changes may persist into adult life and lead to diseases like T2D and CVD. In other studies, Barker and colleagues have reported a correlation between birth weight and high blood pressure in three adult cohorts in the UK. $[59,60]$ Later on, it was suggested that fetal undernutrition during different stages of pregnancy may have different outcomes. This concept came out from the famine studies conducted on individuals exposed to the Dutch Famine (1944 - 1945) during their intrauterine life. The results showed that individuals exposed to famine in utero during the first two trimesters of pregnancy had a higher prevalence (80\%) of overweight than those from nonfamine areas. [61] On the other hand, men and women exposed to the famine in the last trimester were at greater risk of impaired glucose tolerance and T2D than non-exposed people or those exposed early in gestation. Moreover, a greater risk of developing CHD, obesity and dyslipidaemia was found to be associated with exposure to famine in early gestation. [62, 63] The findings from the Dutch Famine studies have made the important point that transient prenatal nutritional deprivation can have adverse long-term effects on health without necessarily altering birth weight. Follow-up of people who were in utero, when their mothers were exposed to the Biafran (1967-1970) [64] and Chinese (1959-1961) [65] famines, or 
themselves exposed to famine during infancy have also shown increased incidences of hypertension, impaired glucose tolerance, diabetes, overweight and obesity compared with controls conceived after famine.

A number of studies have replicated Barker's findings and reported an inverse association between birth weight and risk of CVD and diabetes later in life. [66-70] A recent metaanalysis, assessing the same association, reported that each $1 \mathrm{~kg}$ increase in birth weight was found to be associated with 10-20\% reduction in the risk for developing CVD later in life. [71] In addition to CVD, the association of low birth weight (LBW) with a range of established CVD risk factors (blood pressure, total cholesterol, triglycerides, and hyperglycemia, high total and LDL-cholesterol and insulin resistance) has also been reported in the studies. [72, 73] Moreover, a systematic analysis including 66,000 people from different populations also showed an association between LBW and increased blood pressure in adulthood. [74]

\subsection{Mechanisms proposed to explain the association between birth weight and CVD}

Although several epidemiological studies have confirmed the association between restricted fetal growth and subsequent risk of CVD and T2D, the mechanistic pathways underlying this association are not yet completely understood. Different concepts have been suggested to explain the underlying mechanism. The first concept was fetal programming or the thrifty phenotype hypothesis, suggesting that undernutrition during intrauterine life alone or in association with postnatal catch-up growth may permanently program the risk of T2D and CVD later in life. Additionally, it has been suggested that epigenetic mechanisms may be crucial in the permanent reprogramming of the genome in response to early experiences and exposures. [75] Alternatively, it was proposed that common genetic factors influencing both intrauterine growth as well as insulin resistance and CVD may be responsible for the association between LBW and increased risk of CVD. Other researchers thought that other unmeasured confounders, such as socioeconomic or familial factors, might determine this association. These hypotheses will be discussed in detail further in this chapter.

\subsubsection{The thrifty phenotype or fetal programming hypothesis}

Fetal programming is described as a phenomenon where permanent and long-term changes take place in the metabolism and structure of the growing fetus. These changes can be made by a relatively brief stimulus during the critical phase of embryo-fetal development, when new tissues and organs are developed in utero. [76] Accordingly, malnutrition or ingestion of 
toxins during fetal development can affect organ development, fetal growth and fetal survival by disrupting the sensitive intrauterine homeostasis, which guarantees normal fetal growth and metabolism.

As mentioned earlier, the concept of early origin of later disease arose from the studies of Forsdahl, Barker and Osmond. [58, 59] In the early 1990s Barker and colleagues proposed the 'thrifty phenotype hypothesis' in the etiology of T2D and CVD. [38] This hypothesis postulates that maternal or fetal undernutrition during intrauterine life may permanently change the physiology and metabolism of the growing fetus and ultimately lead to increased risk of insulin resistance, T2D and CVD later in life [57] Therefore, during this critical phase of intrauterine embryo-fetal development, adaptations in embryonic or fetal development can lead to long-term changes in fetal structure, metabolism or physiology. Such adaptations may be triggered by an intrauterine hostile environment (for example malnutrition) and lead to cardiovascular and endocrine disease in later life.

Adverse events during intrauterine life that slow down the process of fetal growth may increase risk of T2D and CVD in individuals who survived a complicated pregnancy. [77] Alan Lucas explained the physiological mechanism underlying this hypothesis. [78] He suggested that under condition of poor intrauterine nutrition the blood flow and nutrients are redistributed to the most important organs such as the brain, while energy uptake of the other organs is reduced. This programs the organ's structure and function and has lasting or lifelong effects on the control of tissue physiology and homeostasis. The fetus has adopted these changes to increase the likelihood of intrauterine survival, which is beneficial in the shortterm but could be harmful later in life.

Several mechanisms have been proposed to explain the intrauterine fetal programming of adult CVD. Firstly, it has been suggested that in response to maternal or fetal undernutrition some changes occur in the structure of vasculature such as endothelial impairment and arterial stiffness, which in turn increases the risk of high blood pressure and stroke in adult life. [79] Secondly, some researchers proposed the phenomenon of glomerular hyper-filtration as a result of a decreased number of nephrons and changes in the kidney function. These disturbances in the glomerular filtration can eventually lead to hypertension. [80] Furthermore, it has been suggested that restricted fetal growth may lead to disturbances in the number and function of the pancreatic beta cells, resulting in changes in the hypothalamicpituitary-adrenal axis. [81] Fetal undernutrition, particularly during middle and late gestation, 
has been hypothesized to increase the risk of CVD by programming of blood coagulation, blood pressure, cholesterol metabolism, and hormonal settings. [82]

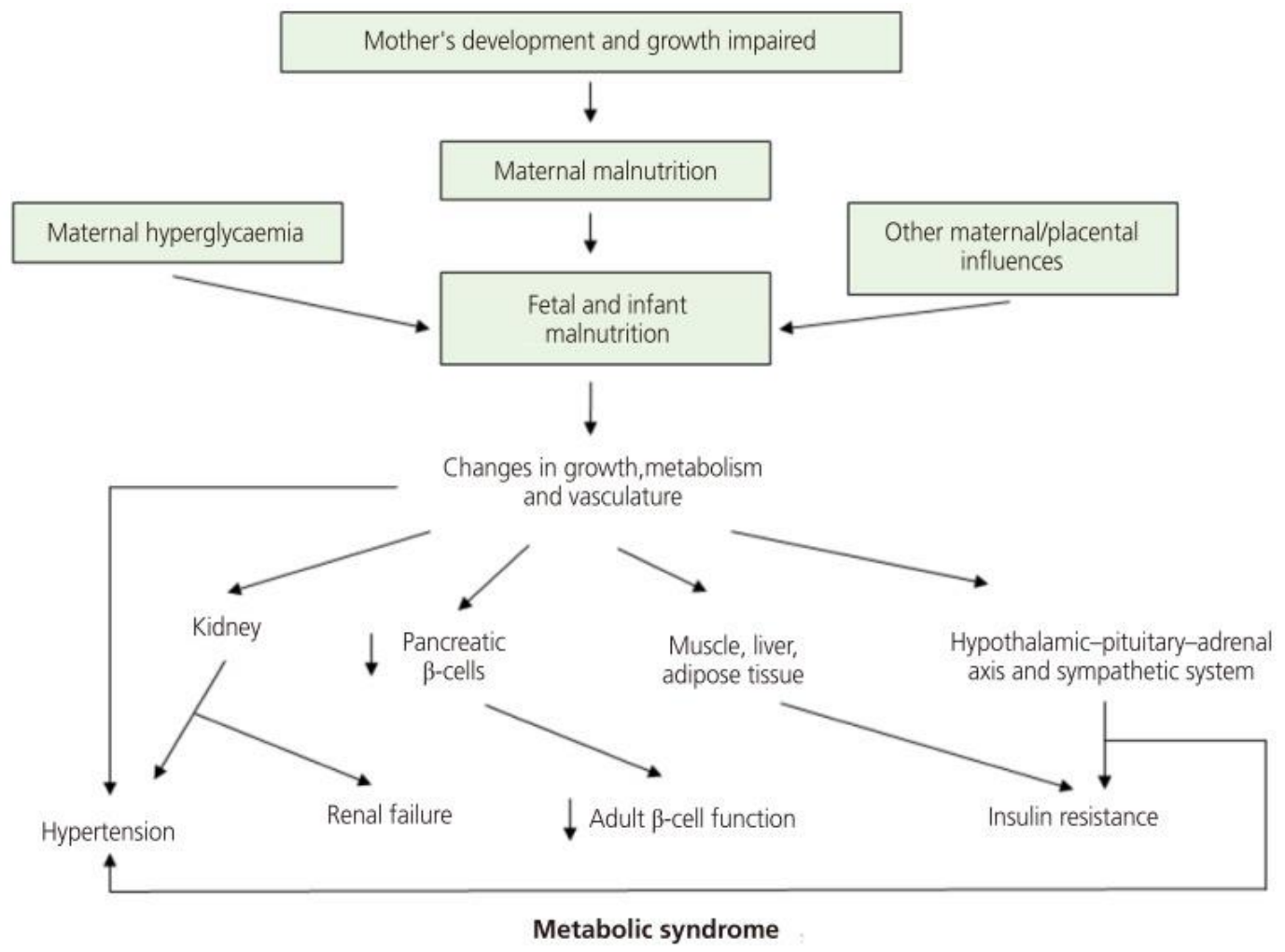

Figure 2: An updated diagram of the thrifty phenotype hypothesis incorporating recent findings and concepts. Also included are new speculative features; maternal hyperglycaemia as a predisposing factor and key roles of the vascular and sympathetic systems, as well as the hypothalamic-pituitary-adrenal axis. [76]

\subsubsection{Catch-up growth}

Growth patterns in postnatal life also seem important in the programming of adult diseases. For example, children who are thin at birth but later on have high catch-up growth and become obese are at high risk of chronic diseases in adult life. [83, 84] A study of young adults showed that those who were born small for gestational age (SGA) and had gained weight rapidly in the first three months of life, had the worst metabolic and cardiovascular risk profile. [85] SGA combined with fast catch-up growth in the first few months, which is the period of rapid cell division, has also been associated with insulin resistance, T2D and CVD. [86] The mechanism behind the detrimental effect of catch-up growth is not fully understood, however, it has been suggested that fetal growth restriction leads to reduced cell numbers, and subsequent catch-up growth is achieved by overgrowth of a limited cell mass. 


\subsubsection{Over-nutrition hypothesis}

Research related to fetal programming of chronic disease mainly focuses on poor maternal and/or fetal nutrition. But during the last few decades, interest in potential health risks related to maternal overnutrition has also emerged. There is evidence that maternal overnutrition and obesity during pregnancy, which commonly leads to increased birth weight, is also associated with adverse health outcomes in the offspring, such as metabolic syndrome and T2D. [87] Maternal obesity may have undesirable effects on the growth of the developing fetus which enhance the chances of obesity and T2D later in life. [88, 89] Fetal macrosomia resulting from oversupply of glucose during gestational diabetes may have adverse programming effects. Furthermore, data from several studies report a U-shaped association between birth weight and T2D. [68] Experimental data showing an association between high maternal fat or cholesterol intake and metabolic syndrome in offspring also support this hypothesis. [90]

\subsubsection{Epigenetic programming}

Epigenetics is the study of heritable changes in gene expression that are not caused by changes in the sequence of DNA. [75] Experimental studies provide evidence that experiences and exposures in early life could increase the susceptibility of chronic disease in adult life by permanent reprogramming of the fetal genome [91] The transmission of programmed phenotypes to the next generation has been established for disorders such as metabolic disturbances, blood pressure, vascular dysfunction and birth weight. [92] Such transmission can be caused by a programmed mother providing a deprived intrauterine environment, thus continuing the cycle of fetal maladaptation. Moreover, it has been suggested that an inadequate supply of amino acids and micronutrients may affect DNA methylation and histone modification in the growing fetus. [93] However, there is a lack of data linking the process of programming to epigenetic changes and risk of metabolic syndrome and related disorders in the adult life among humans.

\subsubsection{Genetic confounding model}

The fetal insulin hypothesis is an alternative mechanism proposed to define the association between LBW and risk of chronic disease later in life. Intrauterine growth is dependent on fetal insulin secretion which is mainly influenced by genetic factors. This hypothesis suggests that common genetic factors, which increase insulin resistance, both in utero and in adult life, may produce two phenotypes: one is a small thin baby and the other is an adult with insulin resistance, diabetes, hypertension and CVD. [94] 
The basis for this model is that genetic factors are of substantial importance for birth weight, $[95,96]$ whereas a number of outcomes of low birth weight such as coronary heart disease, blood pressure and T2D also have a significant genetic component.[97, 98] If the same set of genes are important for birth weight and for cardiovascular diseases later in life, these associations might be explained by genetic influences rather than malnutrition in utero. A recent publication in Nature, as well as several previous studies, proposed that the negative association between size at birth and later risk of CVD may partly be explained by common genetic factors. [94, 99] Previous intergenerational studies, reporting inverse associations between offspring birth weight and risk of diabetes and CVD in their mother and father, provide further evidence regarding the role of shared genetic factors in birth weight and CVD association. [100, 101] The size of the baby is influenced by inherited paternal genetic factors in addition to inherited maternal genetic factors and the maternal intrauterine environment. Given that the same genes impact on both birth weight and adult chronic disease, paternal CVD and diabetes would be associated with lower birth weight in children.

Genome-wide association studies (GWAS) also support the role of common genes on the association between low birth weight and subsequent risk of T2D and CVD. A previous GWAS study identified the association of seven genetic loci with birth weight. They found that out of these seven loci two were associated with T2D and one with blood pressure. [102] Another study concluded that the association between birth weight and increased risk of adult blood pressure is attributable to genetic effects, and not to intrauterine programming. [103] Furthermore, strong inverse genetic correlations were found between birth weight and systolic blood pressure, T2D and coronary artery disease in a multi-ancestry GWAS meta-analysis conducted on birth weight of 153,781 individuals. They identified 60 loci where fetal genotype was associated with birth weight and verified that genetic factors were the major contributor to the negative association between birth weight and future cardio-metabolic risk. [99]

\subsubsection{Socioeconomic and environmental confounding model}

The environmental confounding model proposes that socioeconomic and lifestyle factors, linked with both infant and adult phenotype, may be responsible for the association between birth weight and chronic diseases later in life. [104] It is known that the socioeconomic situation of the parents impact on their offspring birth weight. [105] Moreover, socioeconomic environment in childhood as well as adulthood influence the risk of various chronic diseases, including CVD and T2D in later life. [106, 107] Hence, socioeconomic 
factors might, partially or chiefly, be responsible for the association of birth weight and chronic disease risk in adults. Kramer et al. discussed that socioeconomic status (SES) at birth and maternal diseases both may explain the inverse association of birth weight and subsequent risk of disease in later life. [108] Several previous studies and a meta-analysis investigating the confounding role of SES on the association between birth weight and blood pressure reported that SES impacted this association. [73, 109, 110]

Smoking is another well-known lifestyle factor, which affects both birth weight and CVD. Maternal smoking during pregnancy is an established risk factor for compromised intrauterine growth. Moreover, smoking has been found to be associated with increased blood pressure in the offspring. [111, 112] Thus, it has been suggested that maternal smoking may have an important role in the association between birth weight and CVD in adulthood. [113] Furthermore, a recent multigenerational study reported an influence of maternal smoking during pregnancy on the association between grandparent CVD mortality and offspring birth weight. [101] Correlation in the smoking habits across generations might explain the observed associations. Moreover, these cross-generational correlations may be related to shared cultural or socioeconomic factors.

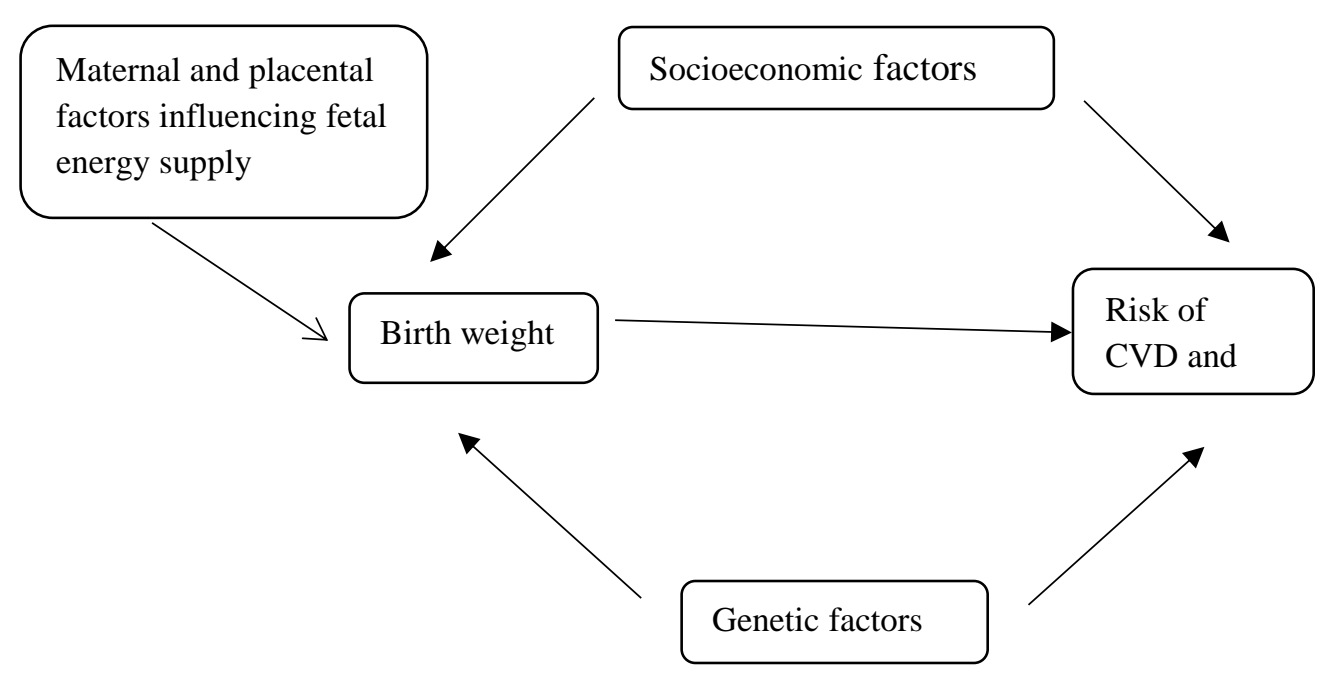

Figure 3: Familial (socioeconomic and genetic) confounding of the association between birth weight and risk of CVD and T2D.[114] 


\subsection{Family-based studies (to investigate the role of shared genetic and environmental factors on birth weight and CVD risk association)}

As described earlier, multiple hypotheses have been proposed to explain the inverse association between birth weight and CVD. However, the underlying mechanisms still need to be clarified. Different family-based designs such as twin, sibling and multigenerational studies have been suggested to understand these underlying mechanisms. The practice of finding more reliable answers to the research questions through incorporation of results from a number of different approaches is known as triangulation. With respect to causal questions, if the results of different approaches all point to the same conclusion, this strengthens confidence in the finding. [115] Thus, comparing associations between family members through these approaches could help to distinguish the competing explanations underlying the inverse association between birth weight and adult CVD.

\subsubsection{Twin studies}

Twin studies may provide the opportunity to differentiate the environmental and genetic mechanism in the association between size at birth and diseases in adult life. Although twins share several or all of their genes as well as their maternal and early family environment, they differ in birth weight. In twins, birth weight is not only affected by specific factors related to each fetus, but also by shared factors such as SES and genes. The basic assumptions about twin similarity are that monozygotic (MZ) twin pairs share $100 \%$ of their genes, dizygotic (DZ) twin pairs share on average $50 \%$ of their segregating genes and all twin pairs share $100 \%$ of common familial environment. [116] If the association between birth weight and adult disease risk is observed within twin pairs, the specific factors related to each fetus are more important. On the other hand, if the association is observed in unpaired twins, then familial factors (genetic and environmental) shared between them are likely to play a role in the association. [117]

Investigations of the association between birth weight and later disease by zygosity can provide evidence for the importance of genetic factors. A stronger association in MZ than DZ twins, suggests a genetic component, whereas stronger associations among DZ twins point towards the importance of shared environment and intrauterine factors. Studies among twins reported negative associations between birth weight and blood pressure, $[117,118]$ dyslipidemia, [119] diabetes, [120, 121] and CHD. [122, 123] However, statistical power was mostly inadequate to confirm different associations among MZ and DZ twins regarding the outcome of CHD. Furthermore, a meta-analysis of twin studies investigating the association 
between birth weight and blood pressure could not provide conclusive evidence regarding the role of genetic or environmental factors on the association. [117] Another study using data from the Swedish Twin Registry showed that the association between birth weight and high blood pressure was not influenced by genetic and environmental factors shared by twins. They suggested that this association was caused by aspects of fetal nutrition represented by birth weight that varies between MZ and DZ pairs. [118] Twin studies have been criticized regarding generalization of their results to the population at large. [124] The intrauterine growth patterns in twins are slightly different from patterns in the singleton births which may lead to different implications of LBW for CVD.

\subsubsection{Sibling studies}

The Sibling study is another family-based design which has been used to assess the confounding role of shared familial factors on birth weight and CVD risk association within individuals. Like dizygotic twins, siblings share $50 \%$ of the genes of their parents, but have different experience of intrauterine environment and gestational age. Singleton siblings share some fixed maternal characteristics, such as maternal height, pelvic size, SES and educational status, although educational status might differ between births. [125] Hence, siblingcomparison studies provide a useful approach to discriminate fixed maternal and family factors with those that are different between full siblings in order to describe association between size at birth and later disease outcome. The analytical approaches for sibship analysis are not very different from comparison of within and between twins, but the results from the sibling comparison design are more generalizable to the population than twin comparisons.

Sibling studies investigating associations between birth weight and adult systolic blood pressure, and CVD events (adjusted for gestational age), [66, 67, 126] suggested that these associations are not explained by fixed familial factors, such as SES, shared by siblings. A large population-based sibling study, reporting associations between LBW and subsequent mortality and morbidity related to CVD, stroke and T2D, suggested that these associations were independent of shared familial confounders and measured covariates, such as maternal and paternal age at childbearing, highest level of education, and history of conviction. [127]

Sibling comparison designs have some notable limitations which may explain discrepancies in the findings. [128] Estimates among siblings are more severely biased by non-shared confounders such as birth order, maternal and paternal age, and gestational age at birth than population-level comparisons [129] and are more sensitive to misclassification of the 
exposure and measurement. [128, 130] Use of a sibling comparison design also limits the population included, affecting power and demonstrating the need for large sample sizes to obtain robust causal evidence.

\subsubsection{Intergenerational studies}

Intergenerational studies are a third family-based design developed to assess the role of common genetic factors underlying the associations between low birth weight and adult risk of CVD. This design is different from twins and sibship studies, as it utilizes information from two generations; exposure in one and outcome in another generation. In some studies, exposure in the more recent generation is associated with outcome in the older generation, in order to examine a direct association, such as the effect of child sleep disturbance on the health of their parents. However, others use exposure in the recent generation as a proxy, rather than a direct exposure, for example when studying the relationship between birth weight in offspring and risk of CVD or diabetes in their parents. The birth weight would serve as a proxy for their parents' own birth weight that might be determined by genetic or environmental factors.

Previous studies, investigating intergenerational associations between offspring birth weight and maternal CVD risk, have demonstrated an inverse association. [131-133] Other studies examined the association among both parents and reported that low birth weight in offspring was also associated with increased CVD mortality in fathers. [100, 101, 134] The association in mothers has been interpreted as indicative of an intergenerational correlation between the birth weight of a mother and her child. $[135,136]$ Moreover, other mechanisms such as fetal programming could also explain this association, because many factors that influence maternal CVD risk could also influence intrauterine environment and eventually the birth weight of a child. [137] The observed association between offspring birth weight and father's risk of CVD is particularly important, as a father mainly influences his child's phenotype through inherited genes. [138] Also, the exposure is determined before the child has experienced its father's environment, except to the extent that the father's environment resembles the mother's environment. Studies on CVD risk association in fathers are comparatively rare compared to studies on mothers.

Apart from mortality studies, some have also assessed the association of offspring birth weight with traditional CVD risk factors among both parents. They showed that low birth weight in offspring is related to increased blood pressure, C-reactive protein and 
inflammatory markers in mothers. [139-141] Furthermore, an inverse association with insulin resistance, BMI and unfavorable levels of lipids has been reported among both parents. [138, 142] Another recent study reported a similar strength of association between birth weight and most CVD risk factors among both parents, suggesting that intrauterine factors are not as important as genetic factors.

Although, an inverse association between offspring birth weight and CVD risk has been reported among both parents in several studies, the strength of association seems to be stronger among mothers. The following potential mechanisms have been proposed to describe the stronger maternal associations reported in previous studies. [125, 134] As discussed already, some of these mechanisms may function simultaneously.

1. A crucial mechanism is the fetal programming hypothesis, suggesting that poor maternal or fetal nutrition in utero may permanently program the structure and metabolism of fetal organs, which in turn increases the risk of chronic diseases later in life (as discussed under point 1.5.1).

2. Maternal health-related behaviours such as unhealthy diet, heavy alcohol consumption and smoking may have direct impact on the offspring birth weight and increase the mother's own risk of CVD as well.

3. The impact of non-pathological, constitutional maternal factors, such as maternal height and weight, influencing birth weight.

4. Genetic imprinting describes how pleiotropic genes, responsible for both low birth weight and high risk of CVD, could more likely be expressed in females than in males (differentially imprinted genes for males and females). Alternatively, a mother might carry genes that mutually influence the risk of low birth weight and CVD risk. These genes could be inherited from either her mother, her father or both and could be found in genomic DNA or mitochondrial DNA.

5. Epigenetic effects could be one of the probable explanations for a stronger motheroffspring effect seen in the studies.

6. In these studies, some of the fathers would not be the biological parents. As paternal association is expected to be driven mainly by genetic factors influencing both birth weight and later CVD, this misclassification of fathers may dilute the paternal association.

7. Pregnancy related health compromising factors, such as maternal undernutrition, may lead to low offspring birth weight due to poor placental growth and smaller pelvic 
size. A mother who is small from any cause such as environmental or genetic, might influence the size of her offspring directly through physiological and anatomical pathways.

8. Associations in fathers may be explained by residual confounders.

\section{Grandparental studies}

Some studies have used a multiple-generational approach and included mortality data of grandparents, in addition to parents, to measure the contribution of potential mechanisms in the association between birth weight and later risk of chronic disease. One population-based study found that ischemic heart disease and cerebrovascular disease among maternal grandmothers were associated with grandchild birth weight. [143] Another study reporting an association between children's birth weight and grandparents' diabetes suggested a role for both environmental (intrauterine) and genetic factors in the association. [144] Furthermore, a Swedish study reported a U-shaped association between offspring birth weight and all-cause as well as cardiovascular disease mortality among maternal grandfathers. For maternal grandmothers, a U-shaped association was found only for cardiovascular disease mortality. However, an inverse association between cardiovascular disease mortality and grandchildren birth weight was observed among paternal grandparents. [145] A recent Norwegian linkage study found a significant relationship between infant's birth weight and all-cause as well as CVD mortality among parents and all four grandparents. [101] The associations in grandparents were largely influenced by maternal smoking during pregnancy, suggesting that maternal smoking and other associated health behaviours might be key mediating factors in the relationship. With few exceptions, these studies did not have enough statistical power to investigate all causes of death. Moreover, they did not use all grandparents of the same index child.

In summary, although a number of studies suggested fetal programming as the main mechanism behind the inverse association between birth weight and chronic diseases risk within individuals, some others have proposed that shared environmental and genetic factors (familial factors) may also be more important. 


\subsection{RATIONALE, AIM AND SPECIFIC OBJECTIVES OF THE STUDY}

\subsection{Rationale}

A large body of evidence suggests that early-life experiences such as intrauterine growth and development are associated with several chronic diseases in adulthood, including CVD and T2D. However, the explanatory pathways for these associations are yet to be clarified. A number of observational studies supported the fetal insulin hypothesis, which suggests that T2D and low birth weight share some genetic determinants. [146-148] Furthermore, several genome-wide association studies found certain genetic variants to be related to both low birth weight and T2D. [149, 150] For CVD, on the other hand, epidemiological study results remain less clear. Several investigators have found that shared environmental factors within families play a modest role. $[114,117,151]$ However, others suggested that common genetic factors, influencing both birth weight and CVD, are more important in the association. [123, 134] Furthermore, most of the previous intergenerational studies providing control for genetic and environmental factors are small and underpowered. Therefore, a more inclusive intergenerational study design including, parents, aunts, uncles and partners of aunts and uncles, has been employed to look at genetic and environmental influences on the association between birth weight and risk of CVD in adult life.

With parents, children share not only genes (50\%) but a familial environment as well. With aunts and uncles, children share half of the genes of their parents and a correlated family environment. Moreover, with partners of aunts and uncles, children are not expected to have any genetic relationship ( $0 \%$ ) but a correlated environment is also likely here. The hypothesis underlying this thesis was that an offspring birth weight and CVD mortality association among parents would highlight the importance of both shared genes and shared environment. A similar strength of association with all classes of aunts and uncles would emphasize the role of shared genes. Any association with the partners of aunts and uncles, with whom offspring do not share genes, would support the role of mechanisms giving rise to correlated environments such as assortative mating. 


\subsection{Main objective}

This population-based study investigated transgenerational links of birth weight in offspring and CVD in parents and their siblings. Investigating this association across generations provided an opportunity to assess possible contributions of shared familial (environmental and genetic) factors on the association between birth weight and adult CVD.

\subsection{Specific objectives}

The research questions raised were:

- Whether the association between offspring birth weight and CVD mortality in parents can be explained by traditional CVD risk factors. (Paper I)

- Can the association observed between offspring birth weight and parental CVD mortality also be observed with respect to the mortality of aunts and uncles and can these associations be explained by traditional CVD risk factors? (Paper II)

- Is offspring birth weight associated with CVD risk factors (BMI, heart rate, systolic blood pressure, lipids and smoking), a risk factor index and education of family members with different genetic relationships (parents, aunts or uncles and partners of aunts or uncles)? (Paper III) 


\subsection{MATERIAL AND METHODS}

\subsection{Data sources}

In this thesis, data from the following sources were used: The Medical Birth Registry of Norway (MBRN), the Cause of Death Registry, the Education Registry (NUDB), three Norwegian Health Surveys; the Cohort of Norway (CONOR), the Age 40 Program and the Norwegian County Study.

\subsubsection{Medical Birth Registry of Norway (MBRN) (Paper I, II, III)}

The Medical Birth Registry of Norway (MBRN) was established in 1967. It covers information about all births in Norway. It is mandatory for all maternity units in Norway to notify each birth to the MBRN. The information is submitted through a standardized electronic form by the attending midwife or physician and it contains the personal identity numbers of the child and parents, as well as information about maternal health before and during pregnancy, and any complications during pregnancy or at birth. Moreover, information about any medication used during pregnancy, intervention of labor, maternal complications during and after birth, whether the baby is born alive and any diagnoses in the child of congenital abnormalities is also reported. Details about the father's occupation and smoking habits, and the mother's occupation, smoking and alcohol habits are only registered if the mother consents. The data about assisted conception also depends on the consent of the mother. All pregnancies that either ended or were terminated after week 12 are notifiable to the MBRN. [152, 153]

\subsubsection{Cause of Death Registry (Paper I, II)}

The Cause of Death Registry provides information about causes of death in Norway for more than $98 \%$ of deaths. It contains data from 1951 onwards. Deaths of Norwegians who die abroad are also registered in the registry. All deaths (about 40,000 each year) are reported by doctors who are required to complete a death certificate by building a logical sequence from the underlying disease to the immediate cause of death. The underlying causes of death are coded according to the International Classification of Disease (ICD) system. The Norwegian Cause of Death Registry used the ICD $8^{\text {th }}, 9^{\text {th }}$ and $10^{\text {th }}$ revision. The 10 th revision of ICD is applied in Norway since 1996. Deaths from all CVDs are coded as ICD 8/9: 390- 459, ICD10: 100 -199 (deaths from IHD are coded as ICD 8/9: 410-414, ICD 10: 120-125 and deaths from stroke are coded as ICD 8/9: 430-438, ICD 10: 160-169). [154] The Cause of Death Registry provides information about emigration, date of death and cause of death. 


\subsubsection{The National Education Database (NUDB) (Paper I, II, III)}

The National Education Database (NUDB) contains information on the highest achieved education for the persons living in Norway. [155] The data is established on reports from educational institutions to Statistics Norway and is updated yearly. The highest achieved education is coded according to the Norwegian Standard Classification. The NUDB comprises individually based statistics on education since 1970 . We used information about level of education of parents, aunts and uncles completed by 2011.

\subsubsection{The Cohort of Norway (CONOR) (Paper I, II, III)}

CONOR is a collection of several Norwegian health surveys conducted in different regions of Norway during the period 1994-2003. The information collected on health and blood samples have been merged into a national database. [156] All the surveys used a common questionnaire including self-reported health, comorbidities such as diabetes, hypertension, osteoporosis and CVD. They also have information on various risk factors, medication intake, socioeconomic and lifestyle factors such as smoking and physical activity. CVD risk factors included are blood pressure, cholesterol, triglycerides, waist and hip circumference, height and weight. All CONOR surveys used a similar procedure for data collection. The overall participation rate in CONOR was $58 \%$.

\subsubsection{The Age 40 Program (1985-99) (Paper I, II, III)}

During the period of 1985-1999 those aged 40-42 were regularly invited to cardiovascular health screening in all Norwegian counties except Oslo. [157, 158] This included people born from 1943 to 1959. According to the database, kept at the Norwegian Institute of Public Health (NIPH), 429,245 individuals participated in the survey. All participants were screened for self-reported health and blood pressure, cholesterol, triglycerides, waist circumference, height and weight. The participation rate in Age 40 program was $70 \%$.

\subsubsection{The Norwegian County Study (1974-88) (Paper I, II, III)}

During the period of 1974-1988, the residents of three Norwegian counties (Finnmark, Sogn og Fjordane and Oppland) were invited to participate in the screening for CVD prevention. These surveys were conducted in three time periods: 1974-78, 1977-83 and 1985-88. All residents in these counties between ages 35-49 years were invited to the screening in 1974 78. The sample invited to the second and third screening was a combination of previous participants and new cohorts. The participation rate in the County Study was 86\%. [159, 160] 


\subsection{Linkages}

In this thesis, the MBRN was linked to nationwide health registries and health surveys. The unique personal identification number, designated to every Norwegian resident, was used to make linkages of the different data sources. To de-identify data, the personal identification numbers were replaced by another code or running-number. The "bridge" between the personal identification numbers and the allocated codes was provided by the Norwegian Institute of Public Health. The linkages of the data files were done by the candidate under guidance from the main supervisor.

\subsection{Study design}

In Paper I and II, a population-based cohort design was used to answer the research questions. A cohort study is the archetype for epidemiologic studies and consists of a group of people followed over a specific time period. The question raised in a cohort study is often whether there is an association between the exposure and the disease of interest. The study intends to reveal a causal action of an exposure on the studied outcome. Because of the nonexperimental approach, observational cohort studies can be used to assess the natural or clinical course of a disease. [161] When the researcher uses data already collected for other purposes, it is called a retrospective or historical cohort study. [162] This is the case when register data is used and the study is performed post-hoc. Whereas a cross-generational study utilizes information from two generations; exposure in one and outcome in another generation. [100] This study used exposure in offspring (birth weight) and outcome in parents, aunts and uncles (cardiovascular disease mortality).

In Paper III, a cross-sectional design was used. In this design all the information is collected at the same point in time. [161] The study design is often used to measure disease prevalence or characteristics of a population. In Paper III, information about the exposure (offspring birth weight) was collected from the MBRN before the information on cardiovascular risk factors (in parents, aunts or uncles and their partners) was obtained. As only information on risk factors at a specific time point was available, this study is not a longitudinal, but rather a cross-sectional study with information on the exposure from the past. It should also be considered that not all information in the study was collected at the same time point.

\subsection{Sample size and power calculation}

Papers I \& II, describe registry-based cohort studies which include large sample sizes, making it possible to study the differences in estimates between family members of different genetic 
relatedness (parents, aunts and uncles). As nationwide data based on the whole population was used in these papers, performing power and sample size calculation was less relevant.

In Paper III, offspring whose parents, aunts and uncles had participated in the population health surveys (CONOR, the Age 40 Program, and the County Study), were eligible for inclusion, which limited the sample size. However, all eligible family members, who had participated in the health surveys, were included and, thus, it was possible to detect the association between offspring birth weight and CVD risk factors in parents, aunts or uncles and their partners. This study could not compare similar sized family relationships, as the important prerequisite was that they (parents, aunts or uncles and partners of aunts or uncles) had participated in the health surveys (Figure 6).

\subsection{Study population}

\subsubsection{Paper I}

The unique personal identification number was used to link data from the multigenerational database, the Medical Birth Registry (MBRN) to the three health surveys (CONOR, the Age 40 Program and the County Study), the National Educational Registry and the Cause of Death Registry. A total of 1,006,557 births (1967 to 2012) were linked with their mothers and fathers who had participated in the health surveys. Newborns with gestational ages of less than 37 weeks or more than 44 weeks and birth weights of less than 1000 gram were excluded. Furthermore, offspring whose parents had not taken part in the health survey or had missing data on CVD risk factors were excluded. Fig 4 provides an overview of the study population in Paper 1. 
Figure 4: Flow chart of the study population (Paper 1)

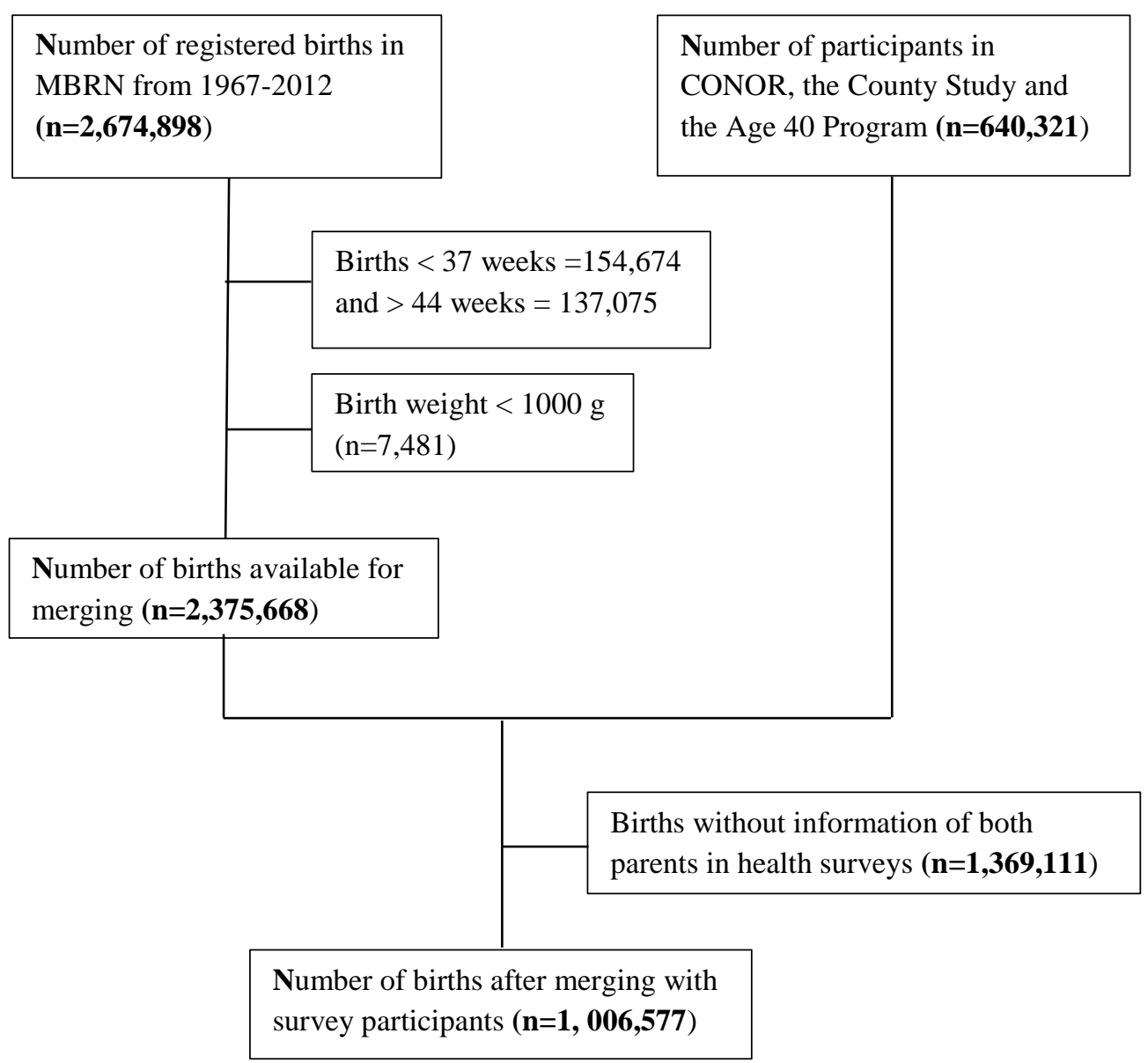

\subsubsection{Paper II}

For Paper II, a multigenerational database (containing information on familial relationships for the population of Norway) was used and full siblings (sharing both mothers and fathers) of the parents (from the index offspring) were identified through personal identification numbers. For the identification of full siblings, we included participants (parents, aunts and uncles) born in or after 1940 because identification of parents proved to be reliable for people born after 1940. [163]

In Paper II, a cohort was created by linking MBRN to the Cause of Death Registry and the Education Registry. Offspring registered in MBRN (1967-2012) were linked to their parents, and at least one maternal and one paternal aunt or uncle. Offspring with gestational ages of less than $37(n=154,674)$ and more than 44 weeks $(n=137,075)$ and birth weight less than $1000 \mathrm{~g}(\mathrm{n}=7,481)$ were excluded from the analyses. Offspring whose parents did not have 
information of any sibling in the database were also excluded $(n=986,768)$. Information on parents and at least one paternal and one maternal aunt or uncle was obtained for 1,353,956 offspring. Furthermore, this cohort was linked to CVD risk factor data recorded in three large Norwegian cardiovascular health surveys (CONOR, the Age 40 Program and the County Study). This subgroup was used to analyze the importance of CVD risk factors on the association between offspring birth weight and CVD mortality in parents and in aunts or uncles.

Figure 5: Flow chart of the study population (Paper II)

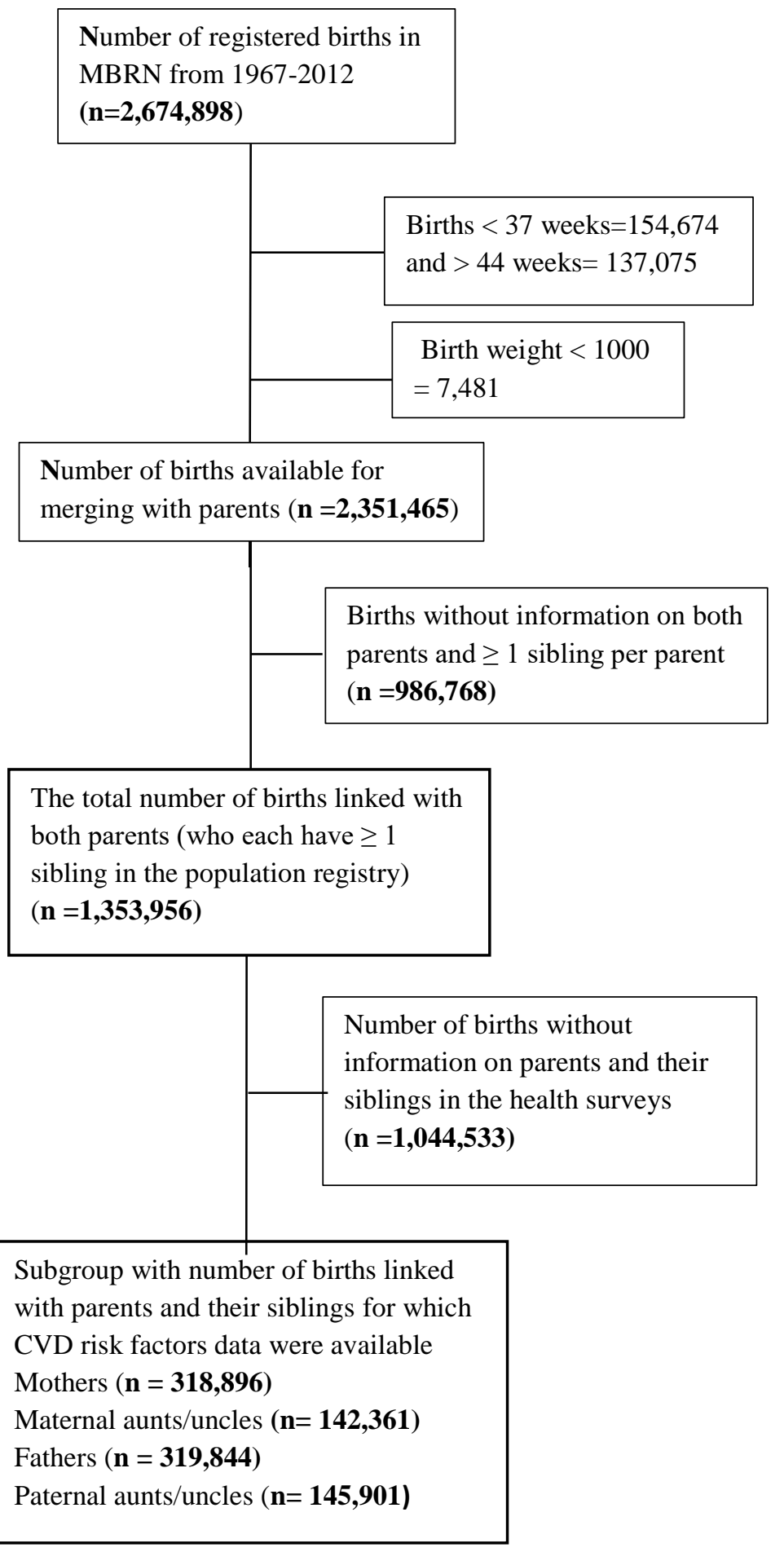




\subsubsection{Paper III}

For Paper III, offspring (MBRN) were linked with parents and their siblings (aunts or uncles) who had participated in the population health surveys (CONOR, the Age 40 Program, and the County Study). The number of offspring (1967-2012) with information on both mother and father (trios), where each parent had information on at least one elder available full sibling in the mutigenerational database was $n=1,532,202$. Births with weight $<600 \mathrm{~g}(\mathrm{n}=1,099)$ and gestational age $>44$ weeks $(n=132,228)$ were not included in the analyses. Offspring were linked with CVD risk factor data on their aunts and uncles within as well as outside the trios. Parents, aunts and uncles with missing information on CVD risk factors were also excluded from the sample. A total of 331,369 offspring could be linked with CVD risk factors on mothers, 330,803 offspring could be linked with fathers, 312,623 with maternal aunts or uncles, and 329,057 with paternal aunts or uncles. Similar sized family relationships could not be compared in this study, because the important criterion for the inclusion was that they had participated in a health survey. Moreover, we identified partners of included aunts and uncles from the multigenerational database in a subgroup. Aunts and uncles may have information of multiple partners in the population register. Only those partners were included, who were partners at the time of the aunt's or uncle's health survey examination. A total of 100,531 offspring were linked with partners of paternal aunts or uncles (with CVD risk factors data), and 91,216 offspring were linked with partners of maternal aunts or uncles. Figure 3 describes the study population for Paper III.

It should be considered that offspring were linked with their aunts and uncles in the health surveys within as well as outside of the trios. This could have an impact on our results. However, in the sensitivity analysis we repeated results in all familial relationships (parents, aunts and uncles) only in trios (Paper 3, supplementary table 2). Results were found to be similar between the two analyses, suggesting that a possible selection bias is not influential in this study. 
Figure 6: Flow chart of the study population (Paper III)

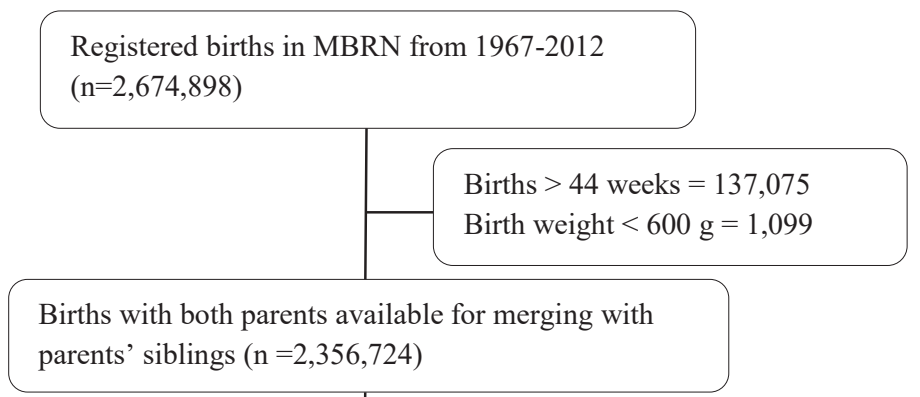

Births with parents without information of eldest available full siblings $(\mathrm{n}=1004,522)$

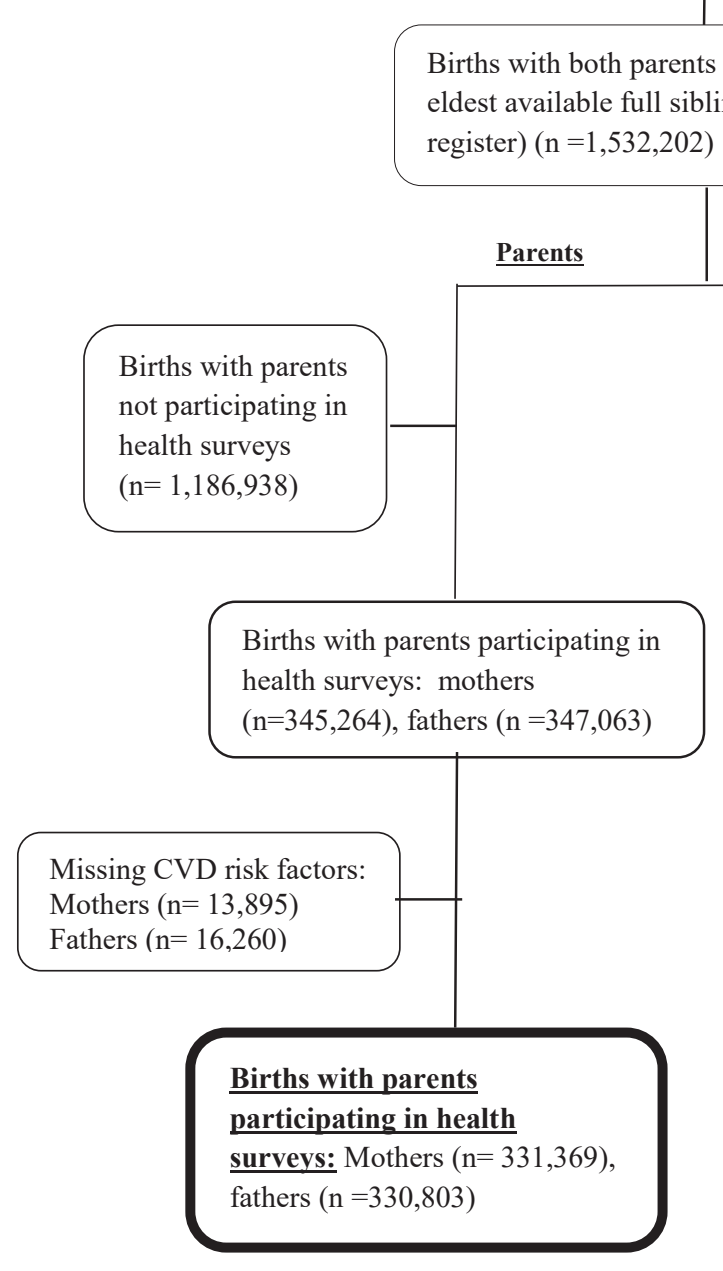




\subsection{Study variables}

\subsubsection{Exposure}

The MBRN registration of birth weight for the whole population was started in 1967. In Norway, the registration of all live and stillbirths from 12 weeks of gestation is mandatory. After delivery, data recorded by healthcare professionals at maternity wards as well as the data from handheld antenatal records, carried by all pregnant women in Norway, is registered in the MBRN registration form. Previous studies have investigated the consistency of the data recorded in the registry with that in the patient medical records and found this validation to be satisfactory. [164-166]

The birth weight in MBRN is registered in grams. Offspring born during 1967 to 2012 were included. The offspring birth weight was analyzed as continuous (Papers II and III) and as categorical variable (Papers I and II). In Paper I, birth weight was categorized into quintiles, whereas in Paper II it was categorized as birth weight for gestational age (small for gestational age (SGA); less than $10^{\text {th }}$ percentile of gestational age, appropriate for gestational age (AGA); $10^{\text {th }}-90^{\text {th }}$ percentile of gestational age and large for gestational age (LGA); more than $90^{\text {th }}$ percentile of gestational age).

\subsubsection{Covariates}

Covariate information was mainly available from the MBRN and from the Education Registry Norway. Information on maternal health before and during pregnancy, age, parity, smoking, offspring sex, year of birth and congenital anomalies coded as 'diseases in offspring' was collected from the MBRN. In all papers, information on education was obtained from the Education Registry Norway. Highest attained education was categorized as " $\leq 9$ years", "1012 years" and " $\geq 13$ years", according to the Norwegian Standard Classification of Education. [167]

The data on traditional CVD risk factors (Body Mass Index (BMI; $\mathrm{kg} / \mathrm{m}^{2}$ ), total cholesterol (TC; mmol/L), triglycerides (TG; mmol/L), systolic and diastolic blood pressure (SBP and DBP; $\mathrm{mmHg}$ ), and smoking) was acquired from the three large Norwegian health surveys; the County Study, the Age 40 Program and Cohort Norway (CONOR) which were conducted during 1974-1988, 1985-1999 and 1994-2003 respectively. 


\subsubsection{Outcomes}

\section{Papers I and II}

The main outcome of interest was CVD mortality (parents, aunts and uncles). Information on cause of death was acquired from the Cause of Death Registry, Norway, using the International Classification of Diseases (ICD) $8^{\text {th }}, 9^{\text {th }}$ and $10^{\text {th }}$ revision. In Cause of death Registry CVD deaths are registered as (ICD 8/9: 390- 459, ICD-10: 100 -199). In Paper II, secondary outcomes were mortality from ischemic heart disease (IHD) and from stroke (IHD: ICD 8/9: 410-414, ICD 10: 120-125, Stroke: ICD 8/9: 430-438, ICD 10: 160-169).

\section{Paper III}

CVD risk factors and CVD risk index were the main outcomes. Information on the studied outcomes was obtained from the County Study, the Age 40 Program and the Cohort of Norway (CONOR). The following cardiovascular risk factors were studied: BMI, smoking, systolic blood pressure, heart rate, cholesterol, triglycerides. This was a cross-sectional study with no follow-up of disease endpoints. In Paper III, CVD risk factors were used as outcome, whereas in Papers I and II, they were covariates.

\subsection{Statistical Methods}

All analyses in our study were performed in Stata software version 14 and 15 (Stata-Corp LP, College Station, Texas. USA).

Both percentages and means with standard deviation were used for the descriptive statistics of the variables. Differences between the groups were tested by chi-square test (categorical variables) and t-tests (continuous variables). The correlation between CVD risk factors (BMI, resting heart rate (RHR), systolic blood pressure (SBP), diastolic blood pressure (DBP), total cholesterol (TC), triglycerides (TG) and height of parents and their siblings was assessed by Pearson's correlation coefficient (Paper III). In all three papers, regression models were used to estimate association between exposure (offspring birth weight) and the studies outcome.

Cox proportional regression models for survival data were used to examine the possible association between exposure (offspring birth weight) and outcome (parental CVD mortality in Paper I and parents and aunts or uncles' CVD mortality in Paper II). The results in Papers I and II were expressed as hazard ratios (HR) with 95\% Confidence Intervals (95\% CI). The assumption of proportional hazards was tested using Schoenfield residuals and graphically assessed with log-log plots of survival. In Paper I, the reduction in HR for CVD mortality in parents was used to describe the magnitude to which CVD risk factors explained the parental 
CVD mortality risk associated with offspring birth weight. In Paper III, linear and logistic regression models were used to investigate the association between offspring birth weight $(\mathrm{kg})$ and each of the CVD risk factors (BMI, RHR, SBP, TC, TG and smoking), and the risk factor index (main outcome) in parents, aunts or uncles as well as partners of aunts and uncles. We also analyzed the association with higher level of education in all familial relations. The associations for the risk factor index were compared between mothers and fathers, between aunts and uncles, and between aunts and uncles and their partners. However, for each individual CVD risk factor the associations were also compared between mothers and fathers. These comparisons were made using interaction term in the models. An estimate with a confidence interval not including one (Cox regression or logistic regression) or zero (linear regression) was considered statistically significant. P-values below 0.05 were considered statistically significant.

In our study, several offspring were nested within the same parents, aunts and uncles (Papers I, II, III). Moreover, some of the aunts and uncles appeared in the data more than once, as they could be the sibling of several mothers or fathers in the sample. If parents have multiple children in the data, this could contribute to inflate precision of estimates due to reduced interindividual variation caused by shared childhood conditions and possible genetic inheritance. To avoid this violation of independence assumptions, all standard errors were adjusted for within-family clustering by computing robust standard errors through the "vce (cluster)" command in Stata. This command effectively adjusts the standard error for within-parent and within-aunts/uncles correlation. [101]

Moreover, the results of Papers I and II must be interpreted as cause-specific HRs and cannot necessarily be interpreted as the cumulative incidence or risk. [168] In a study, examining time to death attributable to CVD causes, the deaths attributable to non-CVD causes are a competing risk. [168] This commonly occurs in the analysis of survival data. Papers I and II investigated cause-specific hazard ratios for mortality (CVD) in parents and in aunts and uncles with a history of small for gestational age (SGA) offspring compared to parents, aunts and uncles with history of appropriate for gestational age (AGA) offspring. Cox regression models were used to calculate cause-specific hazard ratios (HRs) for mortality. Cause-specific hazards quantify the event rate among the ones at risk of developing the event of interest. During the follow-up, parents, aunts and uncles who died from causes other than CVD were censored. The rate and the risk are the same when all-cause mortality is examined, however in the setting of competing risks, they are not same. 


\subsection{Ethics}

This is a sub-study of a larger project entitled “Årsaker til og helsekonsekvenser av fedme og andre risikofaktorer for hjerte- og karsykdommer gjennom livsløpet." The ethical approval for this project was acquired by the Regional Committee for Medical and Health Research Ethics, Norway (2012/827/REK sør-øst A). Moreover, the owners of each register and health survey data (included in this study) had to give approval for the study and the linkages. The participants in the County Study, the Age 40 program and CONOR gave consent for medical research and linkages to the other health registries. Due to large number of women registered in the MBRN, the ethical committee gave approval for exception from consent from these women. 


\subsection{Overview of the included papers in the thesis}

\begin{tabular}{|c|c|c|c|}
\hline Paper & I & II & III \\
\hline Main aim & $\begin{array}{l}\text { This study investigated } \\
\text { the importance of } \\
\text { parental CVD risk factors } \\
\text { in the association } \\
\text { between offspring birth } \\
\text { weight and CVD } \\
\text { mortality among mothers } \\
\text { and fathers. }\end{array}$ & $\begin{array}{l}\text { This study investigated } \\
\text { whether the association } \\
\text { observed between } \\
\text { offspring birth weight } \\
\text { and parental CVD } \\
\text { mortality can also be } \\
\text { observed with respect to } \\
\text { the mortality of aunts } \\
\text { and uncles and whether } \\
\text { these associations are } \\
\text { explained by traditional } \\
\text { CVD risk factors? }\end{array}$ & $\begin{array}{l}\text { This study investigated the } \\
\text { association between offspring } \\
\text { birth weight and CVD risk } \\
\text { factors (BMI, heart rate, systolic } \\
\text { blood pressure, lipids and } \\
\text { smoking), risk factor index and } \\
\text { education of family members at } \\
\text { different genetic relationships } \\
\text { (parents, aunts or uncles and } \\
\text { partners of aunts or uncles) }\end{array}$ \\
\hline Sample size & $\begin{array}{l}1,006,557 \text { offspring with } \\
\text { information of their } \\
\text { parents on CVD mortality } \\
\text { and risk factors }(520,670 \\
\text { for mothers and } 485,887 \\
\text { for fathers). }\end{array}$ & $\begin{array}{l}1,353,956 \text { offspring with } \\
\text { information on their } \\
\text { parents and at least one } \\
\text { paternal and one } \\
\text { maternal aunt and uncle. }\end{array}$ & $\begin{array}{l}331,369 \text { offspring linked with } \\
\text { CVD risk factors data on } \\
\text { mothers, 330,803 with fathers, } \\
312,623 \text { offspring with maternal } \\
\text { aunts and uncles, and } 329,057 \\
\text { offspring with paternal aunt and } \\
\text { uncles. }\end{array}$ \\
\hline Subgroups & $\begin{array}{l}\text { Parents with information } \\
\text { on lifelong smoking } \\
\text { (never smoked before and } \\
\text { ever smoked before). }\end{array}$ & $\begin{array}{l}\text { Parents, aunts and } \\
\text { uncles who participated } \\
\text { in health surveys (CVD } \\
\text { risk factors data). }\end{array}$ & $\begin{array}{l}\text { Partners of aunts and uncles } \\
\text { who participated in health } \\
\text { surveys (CVD risk factors data). }\end{array}$ \\
\hline $\begin{array}{l}\text { Data } \\
\text { sources }\end{array}$ & \multicolumn{2}{|c|}{$\begin{array}{l}\text { The Medical Birth Registry, the Cause of Death } \\
\text { Registry, Cardiovascular health surveys, } \\
\text { multigenerational register. }\end{array}$} & $\begin{array}{l}\text { Medical Birth Registry, } \\
\text { Cardiovascular health surveys, } \\
\text { multigenerational register. }\end{array}$ \\
\hline $\begin{array}{l}\text { Explanatory } \\
\text { variable }\end{array}$ & Offspring birth weight & Offspring birth weight & Offspring birth weight \\
\hline $\begin{array}{l}\text { Main } \\
\text { outcome }\end{array}$ & CVD mortality in parents & $\begin{array}{l}\text { CVD mortality in } \\
\text { parents and in } \\
\text { aunts/uncles }\end{array}$ & $\begin{array}{l}\text { CVD risk factors index in } \\
\text { parents, aunts/uncles and } \\
\text { partners of aunts/uncles }\end{array}$ \\
\hline Covariates & \multicolumn{2}{|c|}{$\begin{array}{l}\text { Maternal: Parity, smoking, diseases before and } \\
\text { during pregnancy } \\
\text { Offspring: sex, gestational age, congenital } \\
\text { anomalies in the newborns, birth order, year of birth. } \\
\text { CVD risk factors: Total cholesterol, HDL-C, } \\
\text { triglycerides, body mass index, blood pressure, }\end{array}$} & $\begin{array}{l}\text { Maternal: age, parity, } \\
\text { gestational age } \\
\text { Offspring: sex } \\
\text { Others: paternal, aunts and } \\
\text { uncles age at risk factors } \\
\text { measurements }\end{array}$ \\
\hline
\end{tabular}




\begin{tabular}{|l|l|l|l|}
\hline & \multicolumn{2}{|l|}{$\begin{array}{l}\text { smoking, heart rate of parents (Papers I and II) and } \\
\text { aunts/uncles (Paper II) } \\
\text { Others: Age, length of education and marital status } \\
\text { of parents (Paper I) and aunts/uncles (Paper II) }\end{array}$} & \\
\hline $\begin{array}{l}\text { Key } \\
\text { comparison }\end{array}$ & $\begin{array}{l}\text { Cohort analyses. } \\
\text { Cox regression analyses } \\
\text { in mothers and fathers }\end{array}$ & $\begin{array}{l}\text { Cox regression analyses } \\
\text { in mothers, father, aunts } \\
\text { and uncles }\end{array}$ & $\begin{array}{l}\text { Linear and logistic regression } \\
\text { analyses in mothers, fathers, } \\
\text { aunts/es and partners of } \\
\text { aunts/uncles }\end{array}$ \\
\hline $\begin{array}{l}\text { Statistical } \\
\text { measures }\end{array}$ & $\begin{array}{l}\text { Hazard ratio and 95\% } \\
\text { confidence interval. }\end{array}$ & $\begin{array}{l}\text { Hazard ratio and 95\% } \\
\text { confidence interval. }\end{array}$ & $\begin{array}{l}\text { Beta-coefficient and odds ratio } \\
\text { with 95\% confidence interval. }\end{array}$ \\
\hline
\end{tabular}




\subsection{SUMMARY OF THE MAIN RESULTS}

\subsection{Paper I}

Offspring birth weight and cardiovascular mortality among parents; the role of cardiovascular risk factors

The objective of this study was to examine the role of parental CVD risk factors on the association between offspring birth weight and CVD mortality among mothers and fathers.

Low birth weight in offspring was related to increased mortality from CVD among both parents. The age-adjusted hazard ratio (HR) for per quintile increase in offspring birth weight for mothers and fathers was 0.84 (0.81-0.86) and 0.95 (0.93-0.96) respectively. Addition of CVD risk factors in the model attenuated the estimates among both parents (mothers; 0.89 (0.86- 0.92), fathers; 0.97 (0.95-0.98)). Adding of maternal diseases before and during pregnancy, disease in offspring, education and marital status attenuated the estimates a little among both parents.

Parental CVD mortality was compared between SGA and non-SGA offspring. The hazard ratio of CVD mortality in mothers and fathers of SGA offspring compared to non-SGA offspring was 1.60 (1.44-1.75) and 1.16 (1.10-1.23), respectively. Among mothers, adjustment for smoking, triglycerides and diabetes reduced the risk to 1.36 (1.25-1.52), 1.57 (1.43-1.73) and 1.58 (1.43-1.79), respectively. Adjustment for diastolic blood pressure (DBP) and systolic blood pressure (SBP) both reduced the risk to 1.53 (1.37-1.66). Among fathers, adjustments for smoking, diastolic blood pressure and systolic blood pressure reduced the risk to $1.08(1.02-1.15), 1.13(1.06-1.19)$ and 1.14 (1.08-1.22), respectively. Adjustment for triglycerides and diabetes both reduced the risk to 1.15 (1.09-1.12).

A subgroup with information on lifelong smoking was used to categorize smoking habits into 'never smoked before' and 'ever smoked before'. In this sensitivity analyses, parental CVD mortality risk was adjusted for 'ever smoked before'. Among fathers, the risk reduced from 1.16 (1.10-1.23) to 1.15 (1.09-1.22) and among mothers from 1.60 (1.48-1.79) to 1.57 (1.421.72). Further adjustment for 'number of pack-years' reduced the risk to $1.10(1.03-1.17)$ in fathers and 1.51(1.35-1.68) in mothers. The impact of ever having smoked was found to be smaller than for current smoking.

An unfavorable risk factor profile was observed among parents of offspring in the lowest birth weight quintile group. The prevalence of smoking and hypertension was higher among 
parents of offspring in the lowest birth weight quintile group. The mean concentration of total cholesterol, systolic and diastolic blood pressure and heart rate was also higher in the same group of parents. The prevalence of obesity was highest among parents of offspring in the highest birth weight quintile group.

These results suggest the significance of CVD risk factors, especially smoking on the association between offspring birth weight and CVD mortality among both parents. Shared environmental factors might be important for the association. A stronger maternal association indicates the role of intrauterine factors.

\subsection{Paper II}

\section{Birth weight in offspring and cardiovascular mortality in their parents, aunts and uncles: a family-based cohort study of $\mathbf{1 . 3 5}$ million births}

This study examined the association between offspring birth weight and CVD mortality in parents, aunts and uncles, and investigated whether these associations can be explained by well-known CVD risk factors.

Parents as well as aunts and uncles of the SGA offspring were less educated compared to the other two groups (AGA and LGA offspring). Smoking during pregnancy was associated with lower offspring birth weight in the subgroup for which smoking data was available. An inverse association between offspring birth weight and CVD mortality from CVD and IHD was observed among both parents and among all four classes of aunts and uncles (maternal as well as paternal aunts and uncles). In mothers and fathers, the hazard ratio of CVD mortality for 1-SD increase in offspring birth weight was $0.72(0.69-0.75)$ and 0.89 (0.86-0.92), respectively. In aunts and uncles, the HRs were between 0.90 (0.86-0.95) and 0.93 (0.910.95). The HR (95\% CI) for CVD mortality in mothers and fathers of SGA offspring compared with AGA offspring were 2.02 (1.85-2.21) and 1.33 (1.26-1.40), respectively. In LGA offspring a reduced hazard for CVD mortality was observed among both parents (HR for mothers; 0.74 (0.63-0.86), for fathers; 0.84 (0.78-0.90). Similar to parents, a higher hazard of CVD mortality was observed in aunts and uncles of SGA offspring whereas a reduced hazard was noted in aunts and uncles of LGA offspring.

In the subsample including mothers, fathers, aunts and uncles, an inverse association between offspring birth weight and CVD mortality was observed among all familial relationships 
which are comparable to the results in Model 1 of the whole data set. Adjustment for CVD risk factors in this subgroup attenuated the associations in parents as well as in aunts and uncles. Additional adjustment for education made a small difference to the estimates. Furthermore, to examine specificity of outcomes - whether the paternal association simply appeared to reflect socio-economic or behavioural confounding, the analysis was repeated in lung cancer mortality as a negative control outcome (Supplementary results, Table 2).

This study demonstrated an inverse association between offspring birth weight and risk of CVD in parents and in all four classes of aunts and uncles. Furthermore, these associations were largely influenced by CVD risk factors. These findings suggest that associations between offspring birth weight and CVD in adult relatives involve both behavioural variables (especially smoking) and shared genetics relating to established CVD risk factors. The strong association in mothers could indicate an intra-uterine effect which may be genetic or environmental.

\subsection{Paper III}

\section{Cardiovascular risk factors in extended family members and birth weight in offspring}

This study investigated the associations between offspring birth weight and each of the CVD risk factors (BMI, heart rate, systolic blood pressure, total serum cholesterol triglycerides, and smoking), and an index of risk factors in parents, aunts and uncles and partners of aunts/uncles. The association with higher education was also analyzed in all familial relationships.

Parents, aunts and uncles of higher birth weight children had healthier CVD risk factor profiles. For each kg increase in birth weight, the mean risk factor index was $-0.14(-0.15$, $0.13)$ in mothers, $-0.11(-0.12,-0.10)$ in fathers, and $-0.02(-0.05,-0.00)$ to $-0.07(-0.09,-0.06)$ in aunts/uncles and their partners. Mother-offspring associations were found to be stronger than father-offspring associations $(\mathrm{P}<0.001)$. The association in maternal aunts was found to be stronger than maternal uncles, and in paternal uncles it was stronger than paternal aunts $(\mathrm{P}$ $<0.001)$. Moreover, the associations in four combined groups of aunts/uncles were stronger than in their combined partners $(\mathrm{P}<0.001)$. Associations for each of the risk factors were observed among all familial relationships. Apart from BMI, the associations were mostly in the negative direction (lower birth weight was associated with higher values). The 
associations in mothers were stronger for most of the CVD risk factors except for TG which was stronger in fathers. The associations for total cholesterol were similar in both parents $(\mathrm{P}=$ 0.750). Moreover, offspring birth weight was found to be associated with reduced smoking and higher education in parents, aunts, uncles and their partners. The odds ratios (ORs) for smoking in mothers and fathers were $(0.61 ; 95 \%$ confidence interval $(\mathrm{CI}): 0.83,0.92)$ and (0.78; 95\% CI: 0.76, 0.79), respectively. For different groups of aunts and uncles, the ORs varied between $(0.83 ; 95 \%$ CI: $0.81,0.85)$ to $(0.88 ; 95 \%$ CI: $0.86,0.90)$. Whereas in the partners of aunts and uncles it varied between $(0.88$; $95 \%$ CI: $0.83,0.92)$ to $(0.95 ; 95 \% \mathrm{CI}$ : $0.83,0.92$ ). The analyses were first adjusted for age of outcome person (mothers, fathers, aunts, uncles and partners of aunts and uncles) at risk factor measurements. Further adjustment for gestational age, offspring sex and maternal parity attenuated the associations marginally in all relationships.

The prevalence of obesity was higher among aunts and uncles and their partners compared to mothers and fathers. However, prevalence of smoking was comparable among parents, all groups of aunts and uncles and their partners. Hypertension and hypercholesterolemia were more common in paternal uncles whereas the proportion of hypertriglyceridemia was comparable in mothers and both groups of aunts, and in fathers and both groups of uncles. The pattern seemed to show much higher risk factors in men than women.

In conclusion, this study revealed profound associations between offspring birth weight and CVD risk factors in extended family members and their partners that go beyond expected associations from known genetic similarities in pedigrees. This suggests that mechanisms like common environmental factors, assortative mating and genetic nurturing may explain these associations. 


\subsection{Supplementary results}

\section{Paper II}

In Paper II, additional analyses were performed to explore the impact of offspring gender on the association between offspring birth weight and parental CVD mortality. The data was analyzed separately for male and female offspring. No difference in the association was observed in either parent.

Table 1: Age-adjusted hazard ratio $(95 \% \mathrm{CI})$ of deaths in parents according to birth weight in female ( $\mathrm{n}=660924)$ and male offspring $(\mathrm{n}=693032)$

Hazard ratio $(95 \% \mathrm{CI})$

\begin{tabular}{|c|c|c|c|c|c|c|c|c|c|}
\hline & \multicolumn{2}{|c|}{ Number of } & $\mathrm{AGA}^{\mathrm{a}}$ & \multicolumn{2}{|l|}{$\mathrm{SGA}^{\mathrm{b}}$} & \multicolumn{2}{|l|}{ LGA $^{\mathrm{c}}$} & \multicolumn{2}{|c|}{ For 1- SD increase in } \\
\hline & \multicolumn{2}{|l|}{ deaths } & & & & & & \multicolumn{2}{|c|}{ offspring birth weight } \\
\hline \multicolumn{10}{|c|}{ Mothers } \\
\hline & $\underline{\text { Female }}$ & $\underline{\text { Male }}$ & & $\underline{\text { Female }}$ & $\underline{\text { Male }}$ & $\underline{\text { Female }}$ & Male & $\underline{\text { Female }}$ & $\underline{\text { Male }}$ \\
\hline CVD & 1826 & 2049 & 1.00 & $\begin{array}{l}2.02 \\
(1.80-2.27)\end{array}$ & $\begin{array}{l}2.09 \\
(1.85-2.37)\end{array}$ & $\begin{array}{l}0.78 \\
(0.61-0.99)\end{array}$ & $\begin{array}{l}0.73 \\
(0.61-0.87)\end{array}$ & $\begin{array}{l}0.71 \\
(0.67-0.75)\end{array}$ & $\begin{array}{l}0.72 \\
(0.68-0.76)\end{array}$ \\
\hline IHD & 626 & 725 & 1.00 & $\begin{array}{l}2.01 \\
(1.64-2.45)\end{array}$ & $\begin{array}{l}2.49 \\
(2.04-3.04)\end{array}$ & $\begin{array}{l}0.68 \\
(0.45-1.05)\end{array}$ & $\begin{array}{l}0.61 \\
(0.44-0.85)\end{array}$ & $\begin{array}{l}0.70 \\
(0.64-0.77)\end{array}$ & $\begin{array}{l}0.70 \\
(0.64-0.77)\end{array}$ \\
\hline Stroke & 665 & 764 & 1.00 & $\begin{array}{l}2.04 \\
(1.68-2.49)\end{array}$ & $\begin{array}{l}2.23 \\
(1.83-2.73)\end{array}$ & $\begin{array}{l}0.65 \\
(0.40-1.03)\end{array}$ & $\begin{array}{l}0.92 \\
(0.70-1.21)\end{array}$ & $\begin{array}{l}0.68 \\
(0.62-0.75)\end{array}$ & $\begin{array}{l}0.67 \\
(0.61-0.73)\end{array}$ \\
\hline \multicolumn{10}{|c|}{ Fathers } \\
\hline CVD & 7884 & 8163 & 1.00 & $\begin{array}{l}1.33 \\
(1.25-1.42)\end{array}$ & $\begin{array}{l}1.33 \\
(1.23-1.43)\end{array}$ & $\begin{array}{l}0.92 \\
(0.82-1.02)\end{array}$ & $\begin{array}{l}0.85 \\
(0.79-0.93)\end{array}$ & $\begin{array}{l}0.88 \\
(0.86-0.91)\end{array}$ & $\begin{array}{l}0.88 \\
(0.86-0.91)\end{array}$ \\
\hline IHD & 4931 & 5159 & 1.00 & $\begin{array}{l}1.32 \\
(1.31-1.73)\end{array}$ & $\begin{array}{l}1.31 \\
(1.19-1.43)\end{array}$ & $\begin{array}{l}0.85 \\
(0.74-0.97)\end{array}$ & $\begin{array}{l}0.85 \\
(0.77-0.95)\end{array}$ & $\begin{array}{l}0.89 \\
(0.86-0.93)\end{array}$ & $\begin{array}{l}0.89 \\
(0.86-0.92)\end{array}$ \\
\hline Stroke & 1161 & 1177 & 1.00 & $\begin{array}{l}1.55 \\
(1.32-1.81)\end{array}$ & $\begin{array}{l}1.50 \\
(1.24-1.82)\end{array}$ & $\begin{array}{l}0.74 \\
(0.54-1.01)\end{array}$ & $\begin{array}{l}0.81 \\
(0.64-1.02)\end{array}$ & $\begin{array}{l}0.84 \\
(0.78-0.90)\end{array}$ & $\begin{array}{l}0.85 \\
(0.79-0.91)\end{array}$ \\
\hline
\end{tabular}

a AGA (between $10-90^{\text {th }}$ percentiles of birth weight)

${ }^{\mathrm{b}} \mathrm{SGA}$ (less than $10^{\text {th }}$ percentile of birth weight)

${ }^{\mathrm{c}}$ LGA (more than $90^{\text {th }}$ percentile of birth weight)

CVD (cardiovascular disease), IHD (ischemic heart disease)

SD (standard deviation) 
To examine specificity of outcomes, whether the paternal association appears to reflect socioeconomic or behavioural confounding, the analysis was repeated with lung cancer mortality as outcome. The patterns of mortality in lung cancer were similar to those observed for CVD mortality for all relationships (supplementary Table 2). This similar trend of associations with lung cancer mortality reflects the significance of behavioural confounders in paternal associations.

Table 2: Hazard ratio (95\% CI) of lung cancer mortality in parents and in aunts and uncles according to offspring birth weight

Hazard ratio $(95 \% \mathrm{CI})$

\begin{tabular}{|c|c|c|c|c|c|}
\hline & Number & $\mathrm{AGA}^{\mathrm{a}}$ & $\mathrm{SGA}^{\mathrm{b}}$ & LGA $^{\mathrm{c}}$ & For 1- SD increase in \\
\hline & of deaths & & & & offspring birth weight \\
\hline Mothers $^{\mathrm{d}}$ & 3550 & 1.00 & $1.90(1.73-2.09)$ & $0.45(0.38-0.58)$ & $0.68(0.65-0.71)$ \\
\hline Maternal aunts $^{\mathrm{d}}$ & 2598 & 1.00 & $1.46(1.31-1.70)$ & $0.85(0.72-1.30)$ & $0.90(0.82-0.92)$ \\
\hline Maternal uncles ${ }^{\mathrm{d}}$ & 3589 & 1.00 & $1.17(1.05-1.31)$ & $0.81(0.70-0.94)$ & $0.97(0.87-0.95)$ \\
\hline Fathers $^{\mathrm{d}}$ & 5608 & 1.00 & $1.32(1.21-1.44)$ & $0.88(0.79-0.99)$ & $0.87(0-85-0.91)$ \\
\hline Paternal aunts $^{\mathrm{d}}$ & 2391 & 1.00 & $1.26(1.12-1.42)$ & $0.90(0.77-1.05)$ & $0.91(0.87-0.96)$ \\
\hline Paternal uncles ${ }^{\mathrm{d}}$ & 4409 & 1.00 & $1.12(1.01-1.24)$ & $0.95(0.87-1.12)$ & $0.97(0.93-1.01)$ \\
\hline
\end{tabular}

${ }^{\text {a }}$ AGA (between $10-90^{\text {th }}$ percentile of birth weight)

${ }^{\mathrm{b}} \mathrm{SGA}$ (less than $10^{\text {th }}$ percentile of birth weight)

${ }^{\mathrm{c}}$ LGA (more than $90^{\text {th }}$ percentile of birth weight)

${ }^{d}$ Number of offspring linked with parents ( $\mathrm{n}=1351$ 897), maternal aunts ( $\mathrm{n}=615$ 959), maternal uncles ( $\mathrm{n}=664$ 986), paternal aunts $(n=633390)$, paternal uncles $(n=681061)$

SD (standard deviation) 


\subsection{DISCUSSION}

\subsection{Methodological consideration}

\subsubsection{Study design}

The data for all the included papers was attained from registries and health surveys. This provides large study populations and long follow-up at a low cost and short time. The use of registries reduces bias due to non-response and loss to follow-up. However, there are some limitations in studies relying on existing records, such as missing information of interest or poor data quality. These limitations are discussed in this section.

\subsubsection{Internal validity}

Two types of errors are usually common in epidemiological studies. The first type is random error, which is defined as the variability in the data that cannot be readily explained. [169] The second type is systematic error (bias) referred to as errors that arise from the way study participants have been selected (selection bias), the way variables have been measured (information bias), or if factors that can impact on both exposure and outcome have not been controlled for (confounding). Both these types of errors can threaten the internal validity and quality of the study.

\section{Random error}

This type of error can be controlled by increasing the sample size of the study. The study sample in this thesis was quite large, which results in less chances of random error and gives narrow confidence intervals. In epidemiological studies, results are usually given as point estimates with confidence intervals. This allows a description of the precision of the suggested estimate. The confidence interval proposes a range, in which the point estimate lies and, thus, indicates the statistical variation or random error, associated with each point estimate. [169] Statistical significance is often reported with the p-value, which indicates statistically significant results when the p-value is less than 0.05 . However, many epidemiologists advise against this dichotomization of the results as significant or not because this may lead to over interpretation of the findings (that each association is important). [170] In addition to state the null hypothesis, the p-value also tests all the assumptions in the model. A large sample size, which is the case in this thesis, is more likely to result in a small p-value. In order to interpret the results accurately, it is of importance to consider the p-value, the point estimate, different sources of bias and the clinical implications of the findings, altogether. Thus, in these results confidence intervals (CI) were considered along with p-values. 


\section{Systematic error}

This type of error or bias is not affected by increasing the sample size. [169]

\section{Selection bias}

Selection bias occurs when the subjects studied are not representative of the target population for which the conclusions are supposed to be drawn, or if the effect estimate is distorted by factors that influence selection into the study. [171] It can affect generalizability of the study. There are two types of selection bias which need to be considered when analyzing data from health surveys: The non-attendance or under coverage bias and non-response bias. The nonattendance bias is related to the individuals who are not invited (exclusion criteria) or did not want to participate in the surveys. The non-respondent bias describes individuals who participated in the surveys but did not respond to some questions.

Selection bias is often absent or limited in population-based cohort studies because people are not selected into the study, but participation is often a consequence of mandatory reporting. [169] In this study, we selected the eldest available full sibling of each parent. If only one sibling was available in the database, we took it regardless of whether the sibling was older or younger than the parent. The inclusion of mostly eldest sibling (of each parent) may lead to selection bias in our study because siblings who were not selected might be different from those who were selected. However, the selection of eldest siblings (of each parents) provided opportunity for longer follow-ups and in turn maximum number of mortality data in the population registry to investigate the association between birth weight and CVD mortality in aunts and uncles.

The chances of both non-attendance and non-respondent bias are limited in the study, as most data came from national registries (MBRN, the Cause of Death Registry). Moreover, data on CVD risk factors from three Norwegian health surveys (the Age 40 program, the County study and CONOR) conducted to screen CVD risk in the population, have been included in this study. The participation rate in the Age 40 program and the County Study was $70 \%$ and $86 \%$ respectively. The response rate in CONOR was $56 \%$. These high percentages indicate that quite a high proportion of those invited also participated in these surveys. However, the participation rate declined over time and the possibility of selection bias cannot be completely ruled out in this study. Moreover, participants of the health surveys might differ from those who did not participate, as they might have been more health-conscious, compared to those who did not participate. Moreover, population surveys usually face the problem of missing 
data, leading to non-response bias. [172,173] This may have influenced the results of this study. However, participants with missing values on CVD risk factors were excluded when merging data from surveys. Participants, for whom data were missing, were list-wise excluded. The necessary robustness against random variation were provided by the large sample size.

\section{Information bias}

Information bias arises when the information collected about or from study subjects is erroneous. [169]

In register-based research, there will always be a degree of uncertainty about the data quality. There may be some degree of misclassification, both with respect to the exposure and the outcome. This may be a particular problem if the misclassification is differential, meaning that the misclassification is related to other study variables. One example of possible misclassification is inconsistent sequences in reporting from the underlying to direct cause of death. [154] Doctors usually focus more on the immediate cause of death when completing a death certificate; however, registries also provide information about the underlying cause of death. Therefore, there is a possibility that causes of death are imprecisely reported, which may lead to attenuation in effect estimates. Moreover, it has been proposed that men are more likely to receive a correct diagnosis for myocardial infarction than women. No information exists indicating that this is reflected in the registration of cause of death in Norway. [154, 174] Such gender-specific misclassification should lead to smaller effect estimates in women compared with men which was not reflected in these results. In this study, the MBRN was used for information on offspring birth weight, gestational age, maternal diseases before and during pregnancy and the Cause of Death Registry for information on fatal outcomes (CVD mortality). The MBRN and the Cause of Death Registry are considered high quality and almost complete for the Norwegian population. [153,154]

The chances of information bias increase when self-reported data is included in a study. Errors in self-reported data could be due to recall-bias (participants incorrectly recalling information) or acquaintance-bias (participants want to give a good impression, and thus report better outcomes than the true value). In the health surveys, the information about diabetes and smoking habits was gathered through a self-administered questionnaire. Smoking in parents is a confounder for the association between low offspring birth weight and own risk of CVD. We adjusted analyses for parental current smoking and diabetes in Paper I and for 
parents' and aunts' or uncles' current smoking in Paper II. However, chances of residual confounding by maternal smoking during pregnancy cannot be completely excluded in this study.

\section{Immortal time bias}

Immortal person-time refers to a period of follow-up during which, by design, the study outcome cannot occur. [161] This type of bias can be present in a cohort study when one of the entry criteria into the cohort is dependent on survival. Paper II investigated the influence of traditional CVD risk factors on the association between offspring birth weight and CVD mortality in parents and in aunts and uncles in a subgroup for whom CVD risk factor data were available. A parent, aunt and uncle had to be alive at the time CVD risk factors were measured. To avoid immortal-time bias, follow-up started at the date of CVD risk factor measurement, not from the date of the child's birth (as was done for the main analyses). Otherwise, nobody who died between the child's birth and the measurement of their own CVD risk factors could be included in the analysis.

\section{Confounding}

Confounding is an important source of bias in epidemiological research. A confounder is a variable that affects both the exposure and the outcome of interest. Controlling for confounders is a crucial issue in epidemiological studies and failure of controlling for confounding may lead to biased estimates and wrong conclusions. [169] This means that the studied association is actually explained by other variables than the defined exposure. In this study, multivariable regression models were used to adjust for potentially present confounders.

Decisions on which potentially present confounders to include in the analyses were based on existing literature. Birth weight is associated with maternal age, parity, gestational age, BMI and sex of the child. [49] Parental educational status, used as a marker of socioeconomic status, is also associated with offspring birth weight. [175] Moreover, these factors can also influence mothers' and fathers' long-term risk of CVD. [176] Pre-existing disease and diseases in pregnancy are also considered as confounders in the association among mothers.

A genetic influence on traditional CVD risk factors such as high blood pressure, T2D, dyslipidemias and obesity has been reported in previous studies. [23, 34, 177] In addition, these risk factors are strongly influenced by environmental and behavioural factors as well. Therefore, to investigate the influence of shared familial factors, this study adjusted for these 
traditional CVD risk factors when testing the birth weight and CVD mortality associations in all familial relationships (Papers I and II).

A limitation in retrospective cohort studies is that the researcher only has access to a predefined set of variables and may miss interesting information, which could lead to unmeasured confounding. There are two overriding factors that are likely to contribute to the offspring birth weight and parent CVD risk association. One is socioeconomic status and the other is diet. Socioeconomic status is an important confounding factor in parent-offspring associations and may be associated with social stress. Maternal diet is known to be important in providing nutrients required for robust fetal growth, whereas paternal diet may also influence the epigenetic status of sperm. These factors are not assessed in the current study.

Smoking during pregnancy is a recognized risk factor for both adverse birth outcomes and for CVD. Registration of smoking in pregnancy started in the MBRN after 1998. Moreover, since then, this information unfortunately suffered from missing values and underreporting. Thus, we had very few participants with information on 'smoking in pregnancy', and those had short follow-up (Papers I \& II) Therefore, the influence of 'maternal smoking during pregnancy' could not be investigated in this study. However, we did a sensitivity analysis in Paper 1 and examined the effect of 'ever smoked' on the association in a subgroup, assuming that those who were current smokers and had a history of 'ever smoked before' must be smokers in the index pregnancy also. This sensitivity analysis served as a control of smoking in Paper I.

Residual confounding cannot be ruled out, due to unmeasured factors. These include dietary habits, alcohol consumption, physical activity and socioeconomic status. In addition, there may be other, unknown factors influencing the presented estimates.

In conclusion, the study populations were large in this project, reducing the amount of random error. Systematic errors have also been considered and several strategies were employed to keep their influence minimal in this study. Registration in the MBRN and the Cause of Death Registry is mandatory nationwide and the quality of the data is considered valid for large scale epidemiological studies. The overall research question in all three papers was the same. In all three papers, multivariable regression models were conducted to reduce the effect of confounding. Sensitivity analyses have also been conducted to explore the potential effect of other sources of bias or weaknesses in the design of the studies. 


\subsubsection{External validity}

External validity refers to generalizability of the results; the extent to which the findings can be generalized from the study sample to the target population. In order to generalize the results, the study population should be representative for the total population. The articles of this thesis used data from different population registers of Norway, including the MBRN, the Cause of Death Registry, and the Education Registry, which contain information of the whole population including immigrants. The population-based design makes the results likely to be generalizable to other similar populations. However, we should be cautious when generalizing results to other more ethnically diverse populations. Low birth weight is more common among non-Caucasian populations (e.g South Asian), who also have an increased burden of CVD, and the effect of the ethnic composition on the studied associations is not studied frequently.

\subsection{Discussion of main findings}

With the aim of searching for shared familial factors (genetic and environmental) that can contribute to the inverse association between birth weight and subsequent risk of CVD, we have analyzed the intergenerational association between offspring birth weight and CVD mortality in family members with different genetic relationships. In Paper I, the association was examined in both mothers and fathers, whereas in Paper II, a novel approach was used, which investigated the association in extended family members such as aunts and uncles. Paper III investigated the association between offspring birth weight and a CVD risk index in all familial relationships (parents, aunts and uncles). In addition, we studied the association with each CVD risk factor and also with education level. Moreover, Paper III included relatives to whom offspring were not expected to have a genetic relationship; partners of aunts and uncles.

This study shows an inverse association between offspring birth weight and CVD mortality in parents as well as in aunts and uncles. Moreover, these associations were largely influenced by traditional CVD risk factors such as smoking, obesity, TC and TG. These risk factors appeared to be strongly influenced by environmental and behavioural factors, but on the other hand, a genetic predisposition could also be mediated by these CVD risk factors. This suggests that both, shared genetic and environmental factors, may be involved in these associations. Furthermore, the association observed between offspring birth weight and CVD 
risk factors in the partners of aunts and uncles denotes that the associations could also be explained by mechanisms other than the shared genes and environment, such as assortative mating and genetic nurturing or dynastic effects in both nuclear and extended family members (more details below).

\subsubsection{Association between offspring birth weight and CVD risk in parents}

An inverse association between offspring and CVD mortality was found among both mothers and fathers (Papers I and II). Similar associations for mortality from IHD and stroke were also reported among both parents (Paper II). However, the associations in mothers were found to be stronger than fathers and other family members.

These results were in accordance with previous multigenerational studies investigating these associations among both parents. [100, 101, 132, 178] A large cohort study and a metaanalysis, found lower offspring birth weight to be associated with increased risk of CVD among mothers as well as among fathers. [134] Another study, using linkage data, demonstrated a strong association between offspring birth weight and the risk of IHD in mothers. [179] Similar results were observed in other populations as well. [178] Moreover, similar to our findings a recent Norwegian study and a meta-analysis of six studies reported stronger associations in mothers compared to fathers. [100, 134]

To examine the role of shared familial factors, we investigated whether parental CVD risk factors (BMI, blood pressure, total cholesterol, triglycerides and smoking) influence these associations among parents (in a subgroup where data on risk factors was accessible). The associations in mothers and fathers were largely explained by these traditional CVD risk factors (Paper II). Moreover, Paper I investigated the role of parental CVD risk factors in the association between offspring birth weight and CVD mortality among both parents. Interestingly, parental smoking was found to be the most influential risk factor affecting the associations in mothers and fathers (Paper I). Other maternal CVD risk factors such as systolic and diastolic blood pressure and triglycerides also had substantial effects on the association in mothers. In fathers, the influence of these CVD risk factors was found to be very small (Paper I). This difference in the results suggests that there are independent effects in mothers and fathers, some of which may be mediated through intrauterine factors. Moreover, it might be possible that both paternal and maternal smoking may have an epigenetic effect, whereas maternal smoking has the additional direct effect of fetal exposure to the anorectic properties of nicotine. A confounding role of smoking on birth weight and 
CVD risk association has been reported in other studies. [132, 134, 178, 180, 181] However, previous studies mostly investigated the role of smoking during pregnancy on birth weight and CVD risk association among mothers, $[131,132,134,181]$ and only a few explored this association among fathers. [100, 180] The evidence regarding impact of other, especially paternal, CVD risk factors such as blood pressure, cholesterol and triglycerides on the birth weight and parental CVD association is scarce. [138, 178]

The role of maternal smoking during pregnancy on the reported association could not be assessed in this study because the data on smoking in pregnancy was collected in the MBRN from 1998 onwards. Therefore, only a few participants with a short follow up had this information in the study. However, the sensitivity analysis in Paper I, showing the influence of "ever smoked before" on offspring birth weight and CVD mortality association, was a reasonable control of smoking among both parents (Paper I).

In addition to CVD mortality, offspring birth weight was found to be inversely associated with individual CVD risk factors such as resting heart rate, systolic blood pressure, total cholesterol, triglycerides and smoking among both parents. (Paper III). Furthermore, the parents of low birth weight children had an unhealthier CVD risk profile than their counterparts. These associations could be attributed to both shared genetic and environmental factors. Previous studies investigating birth weight and parental CVD risk factor associations also reported associations with high blood pressure among both mothers and fathers. [138, 182] In addition, an inverse association between paternal insulin resistance and low offspring birth weight has been reported in some other studies. [183] Moreover, an intergenerational study indicated that fathers of SGA children had higher BMI and higher levels of glucose compared to fathers of their counterparts. $[142,184]$ In mothers, an association with elevated inflammatory markers such as C-reactive protein and interleukin-6 has also been reported. $[139,140]$ These studies suggest that women may become susceptible to dysregulation of inflammation associated with increased CVD risk $[140,185]$ and also a pathogenic feature of restricted fetal growth, [186] thus demonstrating the observed association between offspring birth weight and CVD mortality in mothers. [187] 


\subsubsection{Associations between offspring birth weight and CVD risk in extended family members (aunts/uncles and their partners)}

Paper II investigated offspring birth weight and CVD mortality associations not only in parents but their aunts and uncles also. Similar to parents, an inverse association between offspring birth weight and CVD mortality was observed among four classes of aunts and uncles (maternal as well as paternal aunts and uncles). Furthermore, the strength of associations was found to be similar among all aunts and uncles.

These results are indicative of a genetic link. To the best of our knowledge, there are no other studies dealing with offspring birth weight and CVD mortality association in aunts and uncles. Therefore, a direct comparison of these results with other studies is not possible. However, previous multigenerational studies reporting inverse associations between grandchild birth weight and grandparent CVD mortality also emphasized the genetic influence on the association. [101, 145] Moreover, contrary to our findings, a previous intergenerational study investigating offspring birth weight and parental sibling characteristics found that maternal aunts but not uncles share important links with offspring birth weight. They propose that genetic effects from mothers are more important than paternal effects. [55]

The role of traditional CVD risk factors on birth weight and CVD mortality associations has been evaluated in aunts and uncles as well (in a subgroup where data on risk factors was accessible). Resembling the associations of low birthweight with CVD mortality in offspring and parents, the associations in four classes of aunts and uncles were attenuated once CVD risk factors were included in the model (Paper II). Our results propose that familial factors shared in nuclear as well as in extended families may be contributing to these associations. [188].

Furthermore, comparable to the parents, a negative association between offspring birth weight and CVD risk factors (resting heart rate, systolic blood pressure, cholesterol, triglycerides and smoking) has been observed in all classes of aunts and uncles (Paper III). In addition, offspring birth weight was found to be associated with reduced smoking and higher education in the partners of aunts and uncles in a subgroup (Paper III). As offspring are not expected to share any genetic relationship with the partners of aunts or uncles, these associations presumably highlight mechanisms related to other than genetic factors. The results suggest that confounding due to family structures is most likely influencing these results and 
assortative mating seemed important in the associations reported with aunts or uncles and their partners (Paper III).

\subsubsection{Explanatory mechanisms}

Various mechanisms could explain the association between low offspring birth weight and increased risk of parental CVD reported in our study. Shared genetic factors, influencing both fetal growth and parental CVD mortality, could be important in these associations. As discussed earlier, the association with paternal CVD mortality was more crucial for the role of common genes, because a father can influence his child's birth weight mainly through inherited genes. Previous studies also highlighted the importance of shared genetic factors. [100, 101, 189] Additionally, shared socioeconomic and environmental factors (e.g. smoking, SES, nutrition) could be another possible explanation for the associations observed among both parents. These two mechanisms (shared genetic and environmental) could lead to similar magnitudes of effects in both mothers and fathers. However, these results persistently showed stronger associations in mothers compared to fathers (Papers I, II, III), suggesting that other potential mechanisms are also important in mother-offspring associations, which could act simultaneously. Intrauterine factors leading to low birth weight in offspring through malnutrition, poor placental growth and maternal pelvic restriction are one possibility. Maternal health-related behaviours such as smoking may have a direct impact on offspring birth weight and the mother's own risk of CVD, and be responsible for a stronger association. In addition, epigenetic effects could be one of the probable explanations for a stronger mother-offspring association reported in our results (as discussed in the introduction).

A similar strength of association between offspring birth weight and CVD mortality reported in all classes of aunts and uncles may also support the role of common genetic factors in the associations. However, if only shared genes were important, the effect sizes for the birth weight and CVD mortality association could be expected to be proportionally higher for both parents than for uncles and aunts. However, it was interesting to see that the associations in fathers were only slightly stronger than those in aunts and uncles (Paper II), suggesting that unobserved confounders for instance dietary habits, physical activity and alcohol intake could be important in the paternal associations. A similar trend of associations with lung cancer mortality also reflected the significance of behavioural and environmental confounders in the paternal association (Paper II). 
Health-related factors such as smoking, obesity and socioeconomic status cluster in families and are maintained into adult life. Siblings share similar home environments, dietary habits and health-related behaviours, particularly when the age difference between them is small. It might be possible that behavioural and environmental factors, shared in the previous generation (parents and their siblings), partly explained the associations in aunts and uncles.

A genetic predisposition of CVD risk factors, such as blood pressure, lipids and obesity, has been reported in previous studies. [27, 34, 35] This may further support the influence of shared genetic factors on the associations reported for parents and for aunts and uncles. Furthermore, smoking behaviours have been linked with some genetic variants. However, evidence regarding common genes associated with both low birth weight and smoking habits is currently not sufficient. [190] Therefore, these results regarding smoking may support some impact of shared behavioural factors on the association.

Moreover, our results could be described by assortative mating, a concept through which individuals select partners on the basis of similar characteristics and behaviours. It is likely that mothers may have children with partners who have similar behaviours, thus creating an environmental effect. Moreover, the associations observed in aunts and uncles and their partners could also be explain by this mechanism. Assortative mating on the basis of similar behaviour/lifestyle factors might create an apparent 'environmental' effect and inflated the associations observed for aunts and uncles and their partners. Another possible explanation of our results could be so called 'genetic nurturing' [191] or 'dynastic effect [192], suggesting that genetic and environmental mechanisms are closely connected with each other. Inherited genetic alleles may be transmitted directly from parents to the offspring. However, nontransmitted genetic alleles from parents can establish their influence through environmentally mediated channels. [191] This genetic nurture or dynastic effect represents an indirect link between parental genotypes and offspring characteristics, which is not caused by children's own biology but may be produced by the family environment, that is connected with parental genes. Kong et al have reported this effect for the educational achievement in offspring. They found an association between non-transmitted parental genetic alleles and educational attainment of the offspring. However, no evidence has been observed for height and BMI of the offspring, suggesting that in wealthy societies genetic nurture effects might be more relevant for behaviour and social factors than for biologically proximal outcomes such as body size. [193] 


\subsection{CONCLUSIONS AND IMPLICATIONS}

- An intergenerational association between offspring birth weight and CVD mortality has been observed among parents as well as among aunts and uncles. The association in mothers was stronger compared to fathers and aunts or uncles. There were no differences in the estimates among the four classes of aunts and uncles (maternal as well as paternal aunts and uncles).

- The associations among parents could be explained by shared genetic factors influencing both fetal growth and parental CVD mortality or by shared socioeconomic and environmental factors.

- A similar strength of association in four groups of aunts and uncles implies the confounding role of shared genes. However, if only shared genes were important, associations in both parents would be expected to be proportionally higher than in uncles or aunts, which was not found in the results of this research, suggesting that other mechanisms may be important in the association.

- A stronger mother-offspring association suggests that multiple potential mechanisms, including intrauterine factors, contribute to the maternal association. These mechanisms could be both genetic and environmental in origin and may act simultaneously.

- Established CVD risk factors contributed substantially to the associations among parents as well as aunts and uncles. Smoking was the most influential risk factor and attenuated the associations among all familial relationships. Both genetic and environmental pathways could be mediated by CVD risk factors, but perhaps more clearly the environmental one. Therefore, the attenuation of estimates after adjustment for CVD risk factors does not necessarily reflect that only genetic factors are important for the associations.

- Both shared genetic as well as behavioural and environmental factors could be important in the intergenerational association between offspring birth weight and CVD 
in adult family members. Moreover, effects from assortative mating and genetic nurturing seem important in both nuclear and extended family members.

- This study suggests that genetic and environmental factors are interlinked and both could be important in the association between birth weight and CVD risk later in life.

- This research work added a large-scale cohort study to the body of literature on mechanisms underlying the association between birth weight and adult CVD.

- We cannot modify an individual's genetic predisposition to the chronic disease.

However, knowledge of heritability can assist in prospectively identifying individuals at risk of CVD. Moreover, the influence of smoking and other CVD risk factors on the associations suggests that public health awareness regarding reduction of these factors in high-risk populations could also help to decrease the incidence of CVD. 


\subsection{FURTURE RESEARCH}

- Results in other ethnic populations could add interesting insights, especially in those populations with differing lifestyle and cultural practices from the Caucasian populations, and where undernutrition in early life is more common and at the same time CVDs have been increasing.

- Future research in the area of 'early origin of later diseases' should investigate the consequences of family structure through Mendelian randomization estimates. This approach in pedigree data would help to address concerns regarding role of assortative mating and genetic nurturing effects. 


\subsection{REFERENCES}

1. Thomas H, Diamond J, Vieco A, Chaudhuri S, Shinnar E, Cromer S, et al. Global Atlas of Cardiovascular Disease 2000-2016: The Path to Prevention and Control. Global Heart. 2018; 13(3): 143-163.

2. Benjamin EJ, Virani SS, Callaway CW, Chamberlain AM, Chang AR, Cheng S, et al. Heart Disease and Stroke Statistics-2018 Update: A Report From the American Heart Association. Circulation, 2018. 137(12): e67- e92.

3. WHO. Cardiovascular diseases (CVDs). 2017 [cited 2019 Oct]; Available from: https://www.who.int/news-room/fact-sheets/detail/cardiovascular-diseases-(cvds).

4. WHO. Cardiovascular disease. [cited 2019 Oct]; Available from: https://www.who.int/cardiovascular_diseases/en/.

5. Smith SC, Collins A, Ferrari R, Holmes DR, Logstrup S, McGhie DV, et al. Our Time: A Call to Save Preventable Death From Cardiovascular Disease (Heart Disease and Stroke). Circulation, 2012. 126(23): 2769-2775.

6. Townsend N, Lauren W, Prachi B, Kremlin W, Mike R, Melanieet N. Cardiovascular disease in Europe: epidemiological update 2016. European Heart Journal, 2016. 37(42): 3232-3245.

7. Sulo G, Igland J, Nygård O, Vollset SE, Ebbing M, Tell GS, et al. Favourable trends in incidence of AMI in Norway during 2001-2009 do not include younger adults: a CVDNOR project. European Journal of Preventive Cardiology, 2014. 21(11): 13581364.

8. Norwegian Institute of Public Health. Cardiovascular disease in Norway 2019 [cited 2019 Sep]. Available from: https://www.fhi.no/en/op/hin/healthdisease/cardiovascular-disease-in-norway---/.

9. Norwegian Institute of Public Health. Norgehelsa statisticbank 2019 [cited 2019 Nov]. Available from: http://www.norgeshelsa.no/norgeshelsa/?language=no.

10. Goff DC, Lloyd-Jones DM, Bennett G, Coady S, D'Agostino RB, Gibbons R, et al. 2013 ACC/AHA guideline on the assessment of cardiovascular risk: a report of the American College of Cardiology/American Heart Association Task Force on Practice Guidelines. Journal of the American College of Cardiology, 2014. 63(25 Pt B): 29352959. 
11. Wilson PW. Cardiovascular disease risk assessment for primary prevention: Risk calculators. 2018 [cited 2019 Dec]. Available from: https://www.uptodate.com/contents/cardiovascular-disease-risk-assessment-forprimary-prevention-risk-calculators

12. Helsedirektoratet. NORRISK 2 - Kalkulator for hjerterisiko 2017. [cited 2019 Dec]. Available from: http://hjerterisiko.helsedirektoratet.no/. .

13. Yusuf S, Steven H, Stephanie Ô, Tony D, Alvaro A, Fernando L, et al. Effect of potentially modifiable risk factors associated with myocardial infarction in 52 countries (the INTERHEART study): case-control study. The Lancet, 2004; 364(9438): 937-952.

14. Björck L, Annika R, Kathleen B, George L, Simon C. Modelling the decreasing coronary heart disease mortality in Sweden between 1986 and 2002. European Heart Journal, 2009; 30(9): 1046-1056.

15. Jenum AK, Graff-Iversen S, Selmer R, Sogaard AJ. [Risk factors for cardiovascular disease and diabetes through three decades]. Tidsskr Nor Laegeforen, 2007; 127(19): 2532-2536.

16. Eggen AE, Mathiesen EB, Wilsgaard T, Jacobsen BK, Njølstad L. Trends in cardiovascular risk factors across levels of education in a general population: is the educational gap increasing? The Troms $\phi$ study 1994-2008. Journal of Epidemiology and Community Health, 2014; 68(8): 712-719.

17. Sulo G, Jannicke I, Vollset SE, Ebbing M, Egeland GM, Ariansen I, et al. Trends in incident acute myocardial infarction in Norway: An updated analysis to 2014 using national data from the CVDNOR project. European Journal of Preventive Cardiology, 2018; 25(10): 1031-1039.

18. Breivik G, Hellevik O. More active and less fit: changes in physical activity in the adult Norwegian population from 1985 to 2011. Sport in Society, 2014; 17(2):157175.

19. Grundtvig M, Hagen TP, German M, Reikvam A. Sex-based differences in premature first myocardial infarction caused by smoking: twice as many years lost by women as by men. European Journal of Cardiovascular Prevention and Rehabilitation, 2009; 16(2): 174-179.

20. Huxley R, Barzi F, Woodward M. Excess risk of fatal coronary heart disease associated with diabetes in men and women: meta-analysis of 37 prospective cohort studies. British Medical Journal, 2006; 332(7533): 73-78. 
21. Dale AC, Nilsen TI, Vatten Lars, Midthjell K, Wiseth R. Diabetes mellitus and risk of fatal ischaemic heart disease by gender: 18 years follow-up of 74914 individuals in the HUNT 1 Study. European Heart Journal, 2007; 28(23): 2924-2929.

22. Brown HL, Warner JJ, Gianos E, Gulati M, Hill AJ, Hollier LM, et al. Promoting Risk Identification and Reduction of Cardiovascular Disease in Women Through Collaboration With Obstetricians and Gynecologists: A Presidential Advisory From the American Heart Association and the American College of Obstetricians and Gynecologists. Circulation, 2018; 137(24): e843-e852.

23. An P, Rice T, Gagnon J, Borecki IB, Pérusse L, Leon AS, et al. Familial aggregation of resting blood pressure and heart rate in a sedentary population*The heritage family study. American Journal of Hypertension, 1999: 12(3): 264-270.

24. Knuiman MW, Divitini ML, Welborn TA, Bartholomew HC. Familial correlations, cohabitation effects, and heritability for cardiovascular risk factors. Annals of Epidemiology, 1996; 6(3): 188-194.

25. Silventoinen K, Jelenkovic A, Sund R, Hur Y-M, Yokoyama Y, Honda C et al. Genetic and environmental effects on body mass index from infancy to the onset of adulthood: an individual-based pooled analysis of 45 twin cohorts participating in the COllaborative project of Development of Anthropometrical measures in Twins (CODATwins) study. The American journal of clinical nutrition, 2016; 104(2): 371379.

26. Zhang S, Liu X, Necheles J, Tsai HJ, Wang G, Wang B, et al., Genetic and environmental influences on serum lipid tracking: a population-based, longitudinal Chinese twin study. Pediatric Research, 2010. 68(4): 316-22.

27. Fasting MH, Nilsen T I, Holmen TL, Vik T. Changes in parental weight and smoking habits and offspring adiposity: data from the HUNT-study. International Journal of Pediatric Obesity, 2011; 6(2-2): 399-407.

28. Li L, Law C, Lo Conte R, Power C. Intergenerational influences on childhood body mass index: the effect of parental body mass index trajectories. The American Journal of Clinical Nutrition, 2008; 89(2): 551-557.

29. Whitaker KL, Whitaker KL, Jarvis MJ, Beeken RJ, Boniface D, Wardle J. Comparing maternal and paternal intergenerational transmission of obesity risk in a large population-based sample. American Journal of Clinical Nutrition, 2010; 91(6): 15601567. 
30. Ajala O, Fr Meaux AE, Hosking J, Metcalf BS, Jeffery AN, Voss LD, et al. The relationship of height and body fat to gender-assortative weight gain in children. A longitudinal cohort study (EarlyBird 44). International Journal of Pediatric Obesity, 2011; 6(3-4): 223-228.

31. Murrin CM, Kelly GE, Tremblay R E, Kelleher CC. Body mass index and height over three generations: evidence from the Lifeways cross-generational cohort study. BMC Public Health, 2012; 12: 81.

32. Kivimaki M, Lawlor DA, Davey Smith G, Elovainio M, Jokela M, KeltikangasJarvinen L, et al. Substantial intergenerational increases in body mass index are not explained by the fetal overnutrition hypothesis: the Cardiovascular Risk in Young Finns Study. American Journal of Clinical Nutrition, 2007; 86(5): 1509-1514.

33. Davey Smith G, Steer C, Leary S, Ness A. Is there an intrauterine influence on obesity? Evidence from parent child associations in the Avon Longitudinal Study of Parents and Children (ALSPAC). Archives of Disease in Childhood, 2007; 92(10): p. 876-880.

34. Garrison RJ, Castelli WP, Feinleib M, Kannel WB, Havlik RJ, Padgett SJ. et al. The Association of Total Cholesterol, Triglycerides and Plasma Lipoprotein Cholesterol Levels in First Degree Relatives and Spouse Pairs. American Journal of Epidemiology, 1979; 110(3): p. 313-321.

35. Havlik RJ, Garrison RJ, Feinleib M, Kannel WB, Castelli WP, et al. Blood pressure aggregation in families. American Journal of Epidemiology, 1979; 110(3): 304-312.

36. Iliadou A, Snieder H. Genetic epidemiological approaches in the study of risk factors for cardiovascular disease. European Journal of Epidemiology, 2004; 19: 209-217.

37. Vik KL, Romundstad P, Carslake D, Davey SG, Nilsen TIL. Comparison of fatheroffspring and mother-offspring associations of cardiovascular risk factors: family linkage within the population-based HUNT Study, Norway. International Journal of Epidemiology, 2014; 43(3): 760-771.

38. Barker DJ, Hales CN, Fall CH, Osmond C, Phipps K, Clark PM. Type 2 (non-insulindependent) diabetes mellitus, hypertension and hyperlipidaemia (syndrome $X$ ): relation to reduced fetal growth. Diabetologia, 1993. 36(1): 62-67.

39. Voigt M, Heineck G, Hesse V. The relationship between maternal characteristics, birth weight and pre-term delivery: evidence from Germany at the end of the 20th century. Economics \& Human Biology, 2004. 2(2): 265-280. 
40. Noor N, Kural M, Joshi T, Pandit D, Patil A. Study of maternal determinants influencing birth weight of newborn. Archives of Medicine and Health Sciences, 2015; 3(2): 239-243.

41. Nordentoft M, Lou HC, Hansen D, Nim J, Pryds O, Rubin P, et al. Intrauterine growth retardation and premature delivery: the influence of maternal smoking and psychosocial factors. American journal of public health, 1996; 86(3): 347-354.

42. Berti C, Cetin I, Agostoni C, Desoye G, Devlieger R, Emmett PM, et al. Pregnancy and Infants' Outcome: Nutritional and Metabolic Implications. Critical Reviews in Food Science and Nutrition, 2016; 56(1): 82-91.

43. Peacock JL, Bland JM, Anderson HR. Effects on birthweight of alcohol and caffeine consumption in smoking women. Journal of epidemiology and community health, 1991; 45(2): 159-163.

44. Bech BH, Frydenberg M, Henriksen TB, Obel C, Olsen J. Coffee Consumption During Pregnancy and Birth Weight: Does Smoking Modify the Association? Journal of Caffeine Research, 2015; 5(2): 65-72.

45. Knopik VS, Marceau K, Palmer RHC, Smith TF, Heath AC. Maternal Smoking During Pregnancy and Offspring Birth Weight: A Genetically-Informed Approach Comparing Multiple Raters. Behavior genetics, 2016; 46(3): 353-364.

46. Mishra S. Effects of Maternal Health and Nutrition on Birth Weight of Infant. International Journal of Science and Research, 2014; 3(6): 855-858.

47. Magnus P, Gjessing H K, Skrondal A, Skjærven R. Paternal contribution to birth weight. Journal of Epidemiology and Community Health, 2001; 55(12): 873-877.

48. Agnihotri B, Antonisamy B, Priya G, Fall C H D, Raghupathy P. Trends in human birth weight across two successive generations. Indian journal of pediatrics, 2008; 75(2): 111-117.

49. Gluckman P, Harding JE. Nutritional and hormonal regulation of fetal growth evolving concepts. Acta Paediatrica, 1994; 83(s399): 60-63.

50. Clausson B, Lichtenstein P, Cnattingius S. Genetic influence on birthweight and gestational length determined by studies in offspring of twins. An International Journal of Obtetrics and Gynecology, 2000. 107(3): 375-381.

51. Svensson AC, Pawitan Y, Cnattingius S, Reilly M, Lichtenstein P. Familial aggregation of small-for-gestational-age births: the importance of fetal genetic effects. American Journal of Obstetetrics and Gynecology, 2006; 194(2): 475-479. 
52. Magnus P. Further evidence for a significant effect of fetal genes on variation in birth weight. Clinical Genetics, 1984; 26(4): 289-296.

53. Magnus P. Causes of variation in birth weight: a study of offspring of twins. Clinical Genetics, 1984; 25(1): 15-24.

54. Magnus P, Berg K, Bjerkedal T, Nance WE. Parental determinants of birth weight. Clinical Genetics, 1984; 26(5): 397-405.

55. Ounsted M, Scott A, Ounsted C. Transmission through the female line of a mechanism constraining human fetal growth $\dagger$. International Journal of Epidemiology, 2008; 37(2): 245-250.

56. Ounsted M, Scott A, Ounsted C. Transmission through the female line of a mechanism constraining human fetal growth $†$. International Journal of Epidemiology, 2008; 37(2): 245-250.

57. Barker DJP, Osmond C. Infant Mortality, Childhood Nutrition, and Ischaemic Heart Disease in England and Wales. The Lancet, 1986; 327(8489): 1077-1081.

58. Barker DJ, Winter PD, Osmond C, Margetts B, Simmonds SJ. Weight in infancy and death from ischaemic heart disease. Lancet, 1989, 2(8663): 577- 580.

59. Barker DJ, Bull AR, Osmond C, Simmonds SJ. Fetal and placental size and risk of hypertension in adult life. British Medical Journal, 1990; 301(6746): 259-262.

60. Barker DJ, Osmond C, Golding J, Kuh D, Wadsworth ME. Growth in utero, blood pressure in childhood and adult life, and mortality from cardiovascular disease. British Medical Journal, 1989; 298(6673): 564-567.

61. Ravelli ACJ, van der Meulen JHP, Michels RPJ, Osmond C, Barker DJP, Hales CN, et al. Glucose tolerance in adults after prenatal exposure to famine. The Lancet, 1998; 351(9097): 173-177.

62. Roseboom TJ, Painter RC, van Abeelen AF, Veenendaal MV, de Rooij SR. Hungry in the womb: what are the consequences? Lessons from the Dutch famine. Maturitas, 2011; 70(2): 141-145.

63. Ravelli GP, Stein ZA, Susser MW. Obesity in young men after famine exposure in utero and early infancy. New England Journal of Medicine, 1976; 295(7):349-353.

64. Hult M, Tornhammar P, Ueda P, Chima C, Bonamy AK, Ozumba B, et al. Hypertension, diabetes and overweight: looming legacies of the Biafran famine. PLoS One, 2010 ; 5(10): e13582. 
65. Li Y, Jaddoe VW, Qi L, He Y, Lai J, Wang J, et al. Exposure to the Chinese famine in early life and the risk of hypertension in adulthood. Journal of Hypertension, 2011; 29(6): 1085-1092.

66. Lawlor DA, Hübinette A, Tynelius P, Leon DA, Smith GD, Rasmussen F. Associations of Gestational Age and Intrauterine Growth With Systolic Blood Pressure in a Family-Based Study of 386485 Men in 331089 Families. Circulation, 2007; 115(5): 562-568.

67. Bergvall N, Anastasia I, Tuvemo T, Cnattingius S. Birth Characteristics and Risk of High Systolic Blood Pressure in Early Adulthood: Socioeconomic Factors and Familial Effects. Epidemiology, 2005; 16(5): 635-640.

68. Harde T, Rodekamp E, Schellong K, Dudenhausen J, Plagemann A. Birth weight and subsequent risk of type 2 diabetes: a meta-analysis. American Journal of Epidemiology, 2007; 165(8): 849-857.

69. Huxley RR, Shiell AW, Law CM. The role of size at birth and postnatal catch-up growth in determining systolic blood pressure: a systematic review of the literature. Journal of Hypertension, 2000; 18(7): 815-831.

70. Pilgaard K, Faerch K, Carstensen B, Poulsen P, Pisinger C, Pedersen O, et al. Low birthweight and premature birth are both associated with type 2 diabetes in a random sample of middle-aged Danes. Diabetologia, 2010; 53(12): 2526-2530.

71. Wang SF, Shu L, Sheng J, Mu M, Wang S, Tao XY, et al. Birth weight and risk of coronary heart disease in adults: a meta-analysis of prospective cohort studies.

Journal of Developmental Origins of Health and Disease, 2014; 5(6): 408-419.

72. Fall CHD, Osmond C, Barker DJP, Clark PMS, Hales CN, Stirling Y, et al. Fetal And Infant Growth And Cardiovascular Risk Factors In Women. British Medical Journal, 1995; 310(6977): 428-432.

73. Hardy R, Sovio U, King VJ, Skidmore PML, Helmsdal G, Olsen SF, et al. Birthweight and blood pressure in five European birth cohort studies: an investigation of confounding factors. European Journal of Public Health, 2005. 16(1): 21-30.

74. Law CM, Shiell AW. Is blood pressure inversely related to birth weight? The strength of evidence from a systematic review of the literature. Journal of Hypertension, 1996; 14(8): 935-941.

75. Ordovas JM, Smith CE. Epigenetics and cardiovascular disease. Nature Reviews Cardiology, 2010, 7(9): 510-519. 
76. Kwon EJ, Kim YJ. What is fetal programming?: a lifetime health is under the control of in utero health. Obstetrics \& gynecology science, 2017; 60(6): 506-519.

77. Barker DJ, Osmond C. Low birth weight and hypertension. British Medical Journal, 1988; 297(6641): 134-135.

78. Lucas A. Programming by early nutrition in man. Ciba Found Symposium, 1991; 156: 38-50.

79. Brawley L, Poston L, Hanson MA. Mechanisms underlying the programming of small artery dysfunction: review of the model using low protein diet in pregnancy in the rat. Archives of physiology and biochemistry, 2003; 111(1): 23-35.

80. Zandi-Nejad K, Luyckx VA, Brenner BM. Adult hypertension and kidney disease: the role of fetal programming. Hypertension, 2006; 47(3): 502-508.

81. Fowden AL, Forhead AJ. Endocrine mechanisms of intrauterine programming. Reproduction, 2004, 127(5): 515-526.

82. Barker DJP. Fetal origins of coronary heart disease. British Medical Journal, 1995; 311(6998): 171-174.

83. Zheng M, Lamb KE, Grimes C, Laws R, Bolton K, Ong KK, et al. Rapid weight gain during infancy and subsequent adiposity: a systematic review and meta-analysis of evidence. Obesity Review, 2018, 19(3): 321-332.

84. Ong KK, Ahmed ML, Emmett PM, Preece MA, Dunger DB. Association between postnatal catch-up growth and obesity in childhood: prospective cohort study. British Medical Journal, 2000, 320(7240): 967-971.

85. Leunissen RW, Kerkhof GF, Stijnen T, Hokken-Koelega A. Timing and tempo of firstyear rapid growth in relation to cardiovascular and metabolic risk profile in early adulthood. Journal of American Medical Association, 2009; 301(21): 2234-2242.

86. Ibanez L, Ong K, Dunger DB, de Zegher F. Early development of adiposity and insulin resistance after catch-up weight gain in small-for-gestational-age children. Journal of Clinical Endocrinology and Metabolism, 2006; 91(6): 2153-2158.

87. Fetita LS, Sobngwi E, Serradas P, Calvo, F, Gautier JF. Consequences of fetal exposure to maternal diabetes in offspring. Journal of Clinical Endocrinology and Metabolism, 2006; 91(10): 3718-3724.

88. Patel N, Pasupathy D, Poston L. Determining the consequences of maternal obesity for offspring health. Experimental Physiology, 2015; 100(12): 1421-1428. 
89. Godfrey KM, Reynolds RM, Prescott SL, Nyirenda M, Jaddoe VWV, Eriksson JG, et al. Influence of maternal obesity on the long-term health of offspring. The lancet. Diabetes \& endocrinology, 2017; 5(1): 53-64.

90. Tellechea ML, Mensegue MF, Pirola CJ. The Association between High Fat Diet around Gestation and Metabolic Syndrome-related Phenotypes in Rats: A Systematic Review and Meta-Analysis. Scientific Reports, 2017; 7(1): 5086.

91. Zambrano E, Martinez-Samayoa PM, Bautista CJ, Deas M, Guillen L, RodriguezGonzalez GL, et al. Sex differences in transgenerational alterations of growth and metabolism in progeny (F2) of female offspring (F1) of rats fed a low protein diet during pregnancy and lactation. Journal of Physiology, 2005, 566(Pt 1): 225-236.

92. Nijland MJ, Ford SP, Nathanielsz PW. Prenatal origins of adult disease. Current Opinion of Obstetrics and Gynecology, 2008; 20(2): 132-138.

93. Pinheiro AR, Salvucci Isadora DM, Aguila MB, Mandarim-de-Lacerda CA. Protein restriction during gestation and/or lactation causes adverse transgenerational effects on biometry and glucose metabolism in F1 and F2 progenies of rats. Clinical Science (Lond), 2008, 114(5): 381-392.

94. Hattersley AT, Tooke JE. The fetal insulin hypothesis: an alternative explanation of the association of low bir thweight with diabetes and vascular disease. The Lancet, 1999; 353(9166): 1789-1792.

95. Johnston LB, Clark AJL, Savage MO. Genetic factors contributing to birth weight. Archives of Disease in Childhood - Fetal and Neonatal Edition, 2002; 86(1): F2-F3.

96. Magnus P, Gjessing HK, Skrondal A, Skjærven R. Paternal contribution to birth weight. Journal of Epidemiology and Community Health, 2001; 55(12): 873-877.

97. Roberts R. Genetics of coronary artery disease: an update. Methodist DeBakey cardiovascular journal, 2014; 10(1): 7-12.

98. Neufeld HN, Goldbourt U. Coronary heart disease: genetic aspects. Circulation, 1983. 67(5): 943-954.

99. Horikoshi M, Beaumont RN, Day FR, Warrington NM, Kooijman MN, FernandezTajes J, et al. Genome-wide associations for birth weight and correlations with adult disease. Nature; 2016. 538: 248-252.

100. Davey Smith G, Sterne J, Tynelius P, Lawlor DA, Rasmusser F. Birth Weight of Offspring and Subsequent Cardiovascular Mortality of the Parents. Epidemiology, 2005; 16(4): 563-569. 
101. Naess O, Stoltenberg C, Hoff DA, Nystad W, Magnus P, Tverdal A, et al. Cardiovascular mortality in relation to birth weight of children and grandchildren in 500,000 Norwegian families. European Heart Journal, 2013; 34(44): 3427-3436.

102. Horikoshi M, Yaghootkar H, Mook-Kanamori DO, Sovio U, Taal H R, Hennig BJ, et al. New loci associated with birth weight identify genetic links between intrauterine growth and adult height and metabolism. Nature Genetics, 2013; 45(1): 76-82.

103. Warrington NM, Beaumont RN, Horikoshi M, Day FR, Helgeland $\varnothing$, Laurin C, et al. Maternal and fetal genetic effects on birth weight and their relevance to cardiometabolic risk factors. Nature Genetics, 2019; 51(5): 804-814.

104. Magnus P. Three interpretations of the association between birth weight and cardiovascular disease. Norsk Epidemiologi, 2009; 15: 41-46.

105. Kramer MS. Intrauterine growth and gestational duration determinants. Pediatrics, 1987; 80(4): 502-511.

106. Lawlor DA, Sterne JA, Tynelius P, Davey Smith G, Rasmussen F. Association of childhood socioeconomic position with cause-specific mortality in a prospective record linkage study of 1,839,384 individuals. American Journal of Epidemiology, 2006; 164(9): 907-915.

107. Ljung R, Hallqvist J. Accumulation of adverse socioeconomic position over the entire life course and the risk of myocardial infarction among men and women: results from the Stockholm Heart Epidemiology Program (SHEEP). Journal of Epidemiology and Community Health, 2006; 60(12): 1080-1084.

108. Kramer MS. Invited Commentary: Association between Restricted Fetal Growth and Adult Chronic Disease: Is It Causal? Is It Important? American Journal of Epidemiology, 2000; 152(7): 605-608.

109. Huxley R, Neil A, Collins R. Unravelling the fetal origins hypothesis: is there really an inverse association between birthweight and subsequent blood pressure? The Lancet, 200;. 360(9334): 659-665.

110. Koupilová I, Leon DA, Vågerö D. Can confounding by sociodemographic and behavioural factors explain the association between size at birth and blood pressure at age 50 in Sweden? Journal of epidemiology and community health, 1997; 51(1): 14-18.

111. Bergel E, Haelterman E, Belizán J, Villar J, Carroli G. Perinatal Factors Associated with Blood Pressure during Childhood. American Journal of Epidemiology, 2000; 151(6): 594-601. 
112. Lawlor DA, Jake MN, Jonathan S, Williams GM, Ebrahim S, Davey Smith G. Associations of Parental, Birth, and Early Life Characteristics With Systolic Blood Pressure at 5 Years of Age. Circulation, 2004, 110(16): 2417-2423.

113. Williams S, Poulton R. Twins and maternal smoking: ordeals for the fetal origins hypothesis? A cohort study. British Medical Journal (Clinical research ed.), 1999; 318(7188): 897-900.

114. Bergvall N, Cnattingius S. Familial (shared environmental and genetic) factors and the fetal origins of cardiovascular diseases and type 2 diabetes: a review of the literature. Journal of Internal Medicine, 2008; 264(3): 205-23.

115. Lawlor DA, Tilling K, Davey Smith G. Triangulation in aetiological epidemiology. International Journal of Epidemiology, 2016; 45(6): 1866-1886.

116. Haworth CMA, Dale P, Plomin R. A Twin Study into the Genetic and Environmental Influences on Academic Performance in Science in nine-year-old Boys and Girls. International journal of science education, 2008; 30(8): 1003-1003.

117. McNeill G, Tuya C, Smith WCS. The role of genetic and environmental factors in the association between birthweight and blood pressure: evidence from meta-analysis of twin studies. International Journal of Epidemiology, 2004; 33(5): 995-1001.

118. Bergvall N, Iliadou A, Johansson S, de Faire U, Kramer MS, Pawitan Y, et al. Genetic and Shared Environmental Factors Do Not Confound the Association Between Birth Weight and Hypertension. Circulation, 2007; 115(23): 2931-2938.

119. Ijzerman R. Evidence for Genetic Factors Explaining the Association Between Birth Weight and Low-Density Lipoprotein Cholesterol and Possible Intrauterine Factors Influencing the Association Between Birth Weight and High-Density Lipoprotein Cholesterol: Analysis in Twins. Journal of Clinical Endocrinology \& Metabolism, 2001; 86: 5479-5484.

120. Johansson S, Iliadou A, Bergvall N, de Faire U, Kramer MS, Pawitan Y, et al. The Association Between Low Birth Weight and Type 2 Diabetes: Contribution of Genetic Factors. Epidemiology, 2008; 19(5): 659-665.

121. Iliadou A, Cnattingius S, Lichtenstein P. Low birthweight and Type 2 diabetes: A study on 11162 Swedish twins. International journal of epidemiology, 2004; 33: 948953.

122. Hübinette A, Cnattingius S, Ekbom A, de Faire U, Kramer M, Lichtenstein P. Birthweight, early environment, and genetics: a study of twins discordant for acute myocardial infarction. The Lancet, 2001; 357(9273): 1997-2001. 
123. Hubinette A, Cnattingius S, Johansson AL, Henriksson C, Lichtenstein P. Birth weight and risk of angina pectoris: analysis in Swedish twins. European Journal of Epidemiology, 2003; 18(6): 539-544.

124. Baird JOC, MacGregor A, Snieder H, Hales CN, Phillips DIW. Testing the fetal origins hypothesis in twins: the Birmingham twin study. Diabetologia, 2001. 44(1): 33-39.

125. Lawlor DA, Mishra GD. Family matters : designing, analysing and understanding family-based studies in life course epidemiology. Oxford University Press; 2009.

126. Leon DA, Ilona K, Vera M, Torsten T, Gunilla L, Rawya M, et al. Fetal, Developmental, and Parental Influences on Childhood Systolic Blood Pressure in 600 Sib Pairs. Circulation, 2005; 112(22): 3478-3485.

127. Class QA, Rickert M E, Lichtenstein P, D'Onofrio BM. Birth weight, physical morbidity, and mortality: a population-based sibling-comparison study. American Journal of Epidemiology, 2014; 179(5): 550-558.

128. Frisell T, Oberg S, Kuja-Halkola R, Sjolander A. Sibling comparison designs: bias from non-shared confounders and measurement error. Epidemiology, 2012. 23(5): 713-720.

129. Donovan SJ, Susser E. Commentary: Advent of sibling designs. International Journal of Epidemiology, 2011; 40(2): 345-349.

130. Keyes KM, Davey Smith G, Susser E. On sibling designs. Epidemiology (Cambridge, Mass.), 2013, 24(3): 473-474.

131. Bonamy AK, Parikh NI, Cnattingius S, Ludvigsson JF, Ingelsson E. Birth characteristics and subsequent risks of maternal cardiovascular disease: effects of gestational age and fetal growth. Circulation, 2011; 124(25): 2839-2846.

132. Friedlander Y, Manor O, Paltiel O, Meiner V, Sharon N, Calderon R, et al. Birth weight of offspring, maternal pre-pregnancy characteristics, and mortality of mothers: the Jerusalem perinatal study cohort. Annals of Epidemiology, 2009, 19(2): 112-117.

133. Pariente G, Sheiner E, Kessous R, Michael S, Shoham-Vardi I. Association between delivery of a small-for-gestational-age neonate and long-term maternal cardiovascular morbidity. International Journal of Gynecology \& Obstetrics, 2013. 123(1): 68-71.

134. Davey Smith G, Hypponen E, Power C, Lawlor DA. Offspring birth weight and parental mortality: prospective observational study and meta-analysis. American Journal of Epidemiology, 2007; 166(2): 160-169. 
135. Hyppönen E, Power C, Davey Smith G. Parental growth at different life stages and offspring birthweight: an intergenerational cohort study. Paediatric and Perinatal Epidemiology, 2004; 18(3): 168-177.

136. Hennessy E, Alberman E. Intergenerational influences affecting birth outcome. I. Birthweight for gestational age in the children of the 1958 British Birth Cohort. Paediatric and Perinatal Epidemiology, 1998; 12(S1): 45-60.

137. Sattar N, Greer IA. Pregnancy complications and maternal cardiovascular risk: opportunities for intervention and screening? British Medical Journal (Clinical research ed.), 2002; 325(7356): 157-160.

138. Myklestad K, Vatten LJ, Magnussen EB, Salvesen KÅ, Davey Smith G, Romundstad PR. Offspring Birth Weight and Cardiovascular Risk in Parents-A Population-based HUNT 2 Study. American Journal of Epidemiology, 2012; 175(6): 546-555.

139. Bartha JL, Romero-Carmona R, Comino-Delgado R. Inflammatory cytokines in intrauterine growth retardation. Acta Obstetricia et Gynecologica Scandinavica, 2003; 82(12): 1099-1102.

140. Ridker PM, Hennekens CH, Buring JE, Rifai N. C-Reactive Protein and Other Markers of Inflammation in the Prediction of Cardiovascular Disease in Women. New England Journal of Medicine, 2000, 342(12): 836-843.

141. Walker BR, McConnachie A, Noon J P, Webb DJ, Watt GC. Contribution of parental blood pressures to association between low birth weight and adult high blood pressure: cross sectional study. British Medical Journal (Clinical research ed.), 1998; 316(7134): 834-837.

142. McCowan LME, North RA, Kho EM, Black MA, Chan EHY, Dekker GA, et al. Paternal Contribution to Small for Gestational Age Babies: A Multicenter Prospective Study. Obesity, 2011; 19(5): 1035-1039.

143. Smith GC, Wood AM, White IR, Pell JP, Hattie J. Birth weight and the risk of cardiovascular disease in the maternal grandparents. American Journal of Epidemiology, 2010; 171(6): 736-744.

144. McCarron P, Davey Smith G, Hattersley AT. Type 2 diabetes in grandparents and birth weight in offspring and grandchildren in the ALSPAC study. Journal of Epidemiology and Community Health, 2004; 58(6): 517-522.

145. Manor O, Koupil I. Birth weight of infants and mortality in their parents and grandparents: the Uppsala Birth Cohort Study. International Journal of Epidemiology, 2010, 39(5): 1264-1276. 
146. Davey Smith G, Sterne JAC, Tynelius P, Rasmussen F. Birth characteristics of offspring and parental diabetes: evidence for the fetal insulin hypothesis. Journal of Epidemiology and Community Health, 2004; 58(2): 126-128.

147. Hyppönen E, Davey Smith G, Power C. Parental diabetes and birth weight of offspring: intergenerational cohort study. British Medical Journal, 2003:; 326(7379): $19-20$.

148. Johansson S, Iliadou A, Bergvall N, de Faire U, Kramer MS, Pawitan Y, et al. The association between low birth weight and type 2 diabetes: contribution of genetic factors. Epidemiology, 2008; 19(5): 659-665.

149. Freathy RM, Bennett AJ, Ring SM, Shields B, Groves CJ, Timpson N J, et al. Type 2 diabetes risk alleles are associated with reduced size at birth. Diabetes, 2009; 58(6): 1428-1433.

150. Freathy RM, Mook-Kanamori DO, Sovio U, Prokopenko I, Timpson NJ, Berry DJ, et al. Variants in ADCY5 and near CCNL1 are associated with fetal growth and birth weight. Nature Genetics, 2010; 42(5): 430-435.

151. Ijzerman RG, Boomsma DI, Stehouwer CD. Intrauterine environmental and genetic influences on the association between birthweight and cardiovascular risk factors: studies in twins as a means of testing the fetal origins hypothesis. Paediatric and Perinatal Epidemiology, 2005; 19 Suppl 1: 10-14.

152. Irgens LM. The Medical Birth Registry of Norway. Epidemiological research and surveillance throughout 30 years. Acta Obstetricia et Gynecologica Scandinavica, 2000; 79(6): 435-439.

153. Irgens LM. [Medical birth registry--an essential resource in perinatal medical research]. Tidsskrift for den Norske laegeforening : tidsskrift for praktisk medicin, ny raekke, 2002; 122(26): 2546-2549.

154. Pedersen AG, Ellingsen CL. Data quality in the Causes of Death Registry. Tidsskr Nor Laegeforen, 2015; 135(8): 768-770.

155. About The National Education Database (NUDB).[cited 2019 Dec] Available from: www.ssb.no/a/english/mikrodata/datasamling/nudb/nudb_20130607-en.html

156. Naess O, Søgaard AJ, Arnesen E, Beckstrøm AC, Bjertness E, Engeland A, et al. Cohort profile: cohort of Norway (CONOR). International journal of epidemiology, 2008; 37(3): 481-485. 
157. Gunhild Wøien ØO, Iversen SG. 22 år med hjerte- og karunders $\emptyset$ kelser $\mathrm{i}$ norske fylker. Bфr vi vare tilfreds med den utviklingen risikofaktorene har hatt? Norsk Epidemiologi, 1997; 7 (2): 255-266.

158. Norwegian Institute of Public Health. Age 40 Program 1985-1999. [cited 2019 Dec] Available from:

https://www.fhi.no/globalassets/dokumenterfiler/studier/helseundersokelsene/rapport40-aringsundersokelsene.pdf.

159. Bjartveit K, Foss OP, Gjervig T, Lund-Larsen PG. The cardiovascular disease study in Norwegian counties. Background and organization. Acta Medica Scandinavica Supplementum, 1979; 634: 1-70.

160. Tverdal A, Foss OP, Leren P, Holme I, Lund-Larsen PG, Bjartveit K. Serum triglycerides as an independent risk factor for death from coronary heart disease in middle-aged Norwegian men. American Journal of Epidemiology, 1989; 129(3): 458465.

161. Rothman KJ, Greenland S, Lash T. Modern Epidemiology. 3rd edition. Lippincott Williams \& Wilkins; 2008.

162. Mann CJ. Observational research methods. Research design II: cohort, cross sectional, and case-control studies. Emergency Medicine Journal, 2003; 20(1): 54-60.

163. Naess O, Hoff DA. The Norwegian Family Based Life Course (NFLC) study: data structure and potential for public health research. International Journal of Public Health, 2013; 58(1): 57-64.

164. Skulstad SM, Igland J, Johannessen A, Bertelsen RJ, Lønnebotn M, Omenaas ER, et al. Validation of maternal reported pregnancy and birth characteristics against the Medical Birth Registry of Norway. PloS one, 2017, 12(8): e0181794- e0181794.

165. Thomsen LCV, Klungsøyr K, Roten LT, Tappert C, Araya E, Bærheim G, et al. Validity of the diagnosis of pre-eclampsia in the Medical Birth Registry of Norway. Acta Obstetricia et Gynecologica Scandinavica, 2013; 92(8): 943-950.

166. Engeland A, Bjørge T, Daltveit A, Vollset SE, Furu K. Validation of disease registration in pregnant women in the Medical Birth Registry of Norway. Acta Obstetricia et Gynecologica Scandinavica, 2009; 88(10): 1083-1089.

167. Statistics Norway. Norwegian Standard Classification of Education 2003 [cited 2019 Dec] Available from: http://www.ssb.no/a/english/publikasjoner/pdf/nos_c751_en/nos_c751_en.pd f. . 
168. Andersen PK, Geskus RB, de Witte T, Putter H. Competing risks in epidemiology: possibilities and pitfalls. International Journal of Epidemiology, 2012; 41(3): 861-870.

169. Rothman KJ. Epidemiology : an introduction. 2nd ed.Oxford: Oxford University Press. 2012.

170. Sterne JA, Davey Smith G. Sifting the evidence-what's wrong with significance tests? British Medical Journal (Clinical research ed.), 2001; 322(7280): 226-231.

171. Rothman KJ, Greenland S, Lash TL. Validity in Epidemiologic Studies, in Modern Epidemiology 3rd Edition. Wolters Kluwer Health/Lippincott Williams and Wilkins. 2008; 128-147.

172. Little RJ, Rubin DB. Statistical Data, Missing, in International Encyclopedia of the Social \& Behavioral Sciences. Pergamon: Oxford; 2001; 15019-15025.

173. Prince M. 9 - Epidemiology, in Core Psychiatry (Third Edition). W.B. Saunders; Oxford: 2012; 115-129.

174. Healy B. The Yentl Syndrome. New England Journal of Medicine, 1991; 325(4): 274276.

175. Fan C, Huang T, Cui F, Gao M, Song L, Wang S. Paternal factors to the offspring birth weight: the 829 birth cohort study. International journal of clinical and experimental medicine, 2015, 8(7): 11370-11378.

176. Kjollesdal MKR, Ariansen I, Mortensen LH, Davey Smith G, Naess O. Educational differences in cardiovascular mortality: The role of shared family factors and cardiovascular risk factors. Scandinavian Journal of Public Health, 2016; 44(8): 744750.

177. Harrap SB, Stebbing M, Hopper JL, Hoang HN, Giles GG. Familial Patterns of Covariation for Cardiovascular Risk Factors in Adults: The Victorian Family Heart Study. American Journal of Epidemiology, 2000, 152(8): 704-715.

178. Davey Smith G, Hart C, Ferrell C, Upton M, Hole D, Hawthorne V, et al. Birth weight of offspring and mortality in the Renfrew and Paisley study: prospective observational study. British Medical Journal, 1997; 315(7117): 1189-1193.

179. Smith GCS, Pell JP, Walsh D. Pregnancy complications and maternal risk of ischaemic heart disease: a retrospective cohort study of 129290 births. The Lancet, 2001; 357(9273): 2002-2006.

180. Li CY, Chen HF, Sung FC, Chen CC, Lu TH, Yang CH, et al. Offspring birth weight and parental cardiovascular mortality. International Journal of Epidemiology, 2010; 39(4): 1082-1090. 
181. Catov JM, Newman AB, Roberts JM, Sutton-Tyrrell KC, Kelsey SF, Harris T, et al. Association Between Infant Birth Weight and Maternal Cardiovascular Risk Factors in the Health, Aging, and Body Composition Study. Annals of Epidemiology, 2007; 17(1): 36-43.

182. Romundstad PR, Davey Smith G, Nilsen TIL, Vatten LJ. Associations of Prepregnancy Cardiovascular Risk Factors with the Offspring's Birth Weight. American Journal of Epidemiology, 2007; 166(12): 1359-1364.

183. Wannamethee SG, Lawlor DA, Whincup PH, Walker M, Ebrahim S, Davey Smith G. Birthweight of offspring and paternal insulin resistance and paternal diabetes in late adulthood: cross sectional survey. Diabetologia, 2004, 47(1): 12-18.

184. De Kort SW, Van Dijk M, Willemsen RH, Ester WA, Viet L, De Rijke YB, et al. Cardiovascular risk factors in parents of short children born small for gestational age. Pediatric research, 2008; 64(1): 91-96.

185. Tracy RP, Rozenn NL, Bruce MP, Diane GI, Rhobert WE, Mary C, et al. Relationship of C-Reactive Protein to Risk of Cardiovascular Disease in the Elderly. Arteriosclerosis, Thrombosis, and Vascular Biology, 1997; 17(6): 1121-1127.

186. Ness RB, Sibai BM. Shared and disparate components of the pathophysiologies of fetal growth restriction and preeclampsia. American Journal of Obstetrics and Gynecology, 2006; 195(1): 40- 49.

187. Dietz PM, Kuklina EV, Bateman BT, Callaghan WM. Assessing Cardiovascular Disease Risk among Young Women with a History of Delivering a Low-Birth-Weight Infant. American Journal of Perinatology, 2013, 30(04): 267-274.

188. Day FR, Loos RJ. Developments in obesity genetics in the era of genome-wide association studies. Journal of Nutrigenetics and Nutrigenomics, 2011; 4(4):222-238.

189. Lawlor DA, Davey Smith G, Whincup P, Wannamethee G, Papacosta O, Dhanjil S, et al. Association between offspring birth weight and atherosclerosis in middle aged men and women: British Regional Heart Study. Journal of Epidemiology and Community Health, 2003; 57(6): 462-463.

190. Loukola A, Hällfors J, Korhonen T, Kaprio J. Genetics and smoking. Current addiction reports, 2014; 1(1): 75-82.

191. Kong A, Thorleifsson G, Frigge ML, Vilhjalmsson BJ, Young AI, Thorgeirsson TE, et al. The nature of nurture: Effects of parental genotypes. Science, 2018; 359(6374): 424-428. 
192. Davies NM, Dickson M, Smith GD, Windmeijer F, van den Berg GJ. The effect of education on adult mortality, health, and income: triangulating across genetic and policy reforms. bioRxiv, 2018: p. 250068.

193. Koellinger PD, Harden KP. Using nature to understand nurture. Science, 2018; 359(6374): 386-387. 
9. ENCLOSED PAPERS I-III

PAPER I 
PAPER II 



\title{
Birthweight in offspring and cardiovascular mortality in their parents, aunts and uncles: a family-based cohort study of $\mathbf{1 . 3 5}$ million births
}

\author{
Fareeha Shaikh, ${ }^{1 *}$ Marte Karoline Kjølllesdal, ${ }^{1}$ David Carslake, ${ }^{2,3}$ \\ Camilla Stoltenberg, ${ }^{4,5}$ George Davey Smith $\mathbb{D}^{2,3}$ and Øyvind Næss ${ }^{1,4}$ \\ ${ }^{1}$ Institute of Health and Society, Faculty of Medicine, University of Oslo, Oslo, Norway, ${ }^{2}$ MRC \\ Integrative Epidemiology Unit at the University of Bristol, Bristol, UK, ${ }^{3}$ Population Health Sciences, \\ Bristol Medical School, University of Bristol, Bristol, UK, ${ }^{4}$ Norwegian Institute of Public Health, Oslo, \\ Norway and ${ }^{5}$ Department of Global Public Health and Primary Care, University of Bergen, Bergen, \\ Norway \\ *Corresponding author. Institute of Health and Society Faculty of Medicine, University of Oslo, Post Box: 1130 Blindern, \\ 0318 0slo, Norway. E-mail: fareeha.shaikh@studmed.uio.no \\ Editorial decision 18 June 2019; Accepted 4 July 2019
}

\begin{abstract}
Background: A link between suboptimal fetal growth and higher risk of cardiovascular disease (CVD) is well documented. It has been difficult to assess the contribution of environmental versus genetic factors to the association, as these factors are closely connected in nuclear families. We investigated the association between offspring birthweight and CVD mortality in parents, aunts and uncles, and examined whether these associations are explained by CVD risk factors.

Methods: We linked Norwegian data from the Medical Birth Registry, the Cause of Death Registry and cardiovascular surveys. A total of 1353956 births (1967-2012) were linked to parents and one maternal and one paternal aunt/uncle. Offspring birthweight and CVD mortality association among all relationships was assessed by hazard ratios (HR) from Cox regressions. The influence of CVD risk factors on the associations was examined in a subgroup.

Results: Offspring birthweight was inversely associated with CVD mortality among parents and aunts/uncles. HR of CVD mortality for one standard deviation (SD) increase in offspring birthweight was $0.72(0.69-0.75)$ in mothers and $0.89(0.86-0.92)$ in fathers. In aunts/uncles, the HRs were between 0.90 (0.86-0.95) and 0.93 (0.91-0.95). Adjustment for CVD risk factors in a subgroup attenuated all the associations.

Conclusions: Birthweight was associated with increased risk of CVD in parents and in aunts/uncles. These associations were largely explained by CVD risk factors. Our findings suggest that associations between offspring birthweight and CVD in adult relatives
\end{abstract}


involve both behavioural variables (especially smoking) and shared genetics relating to established CVD risk factors.

Key words: Birthweight, parents, aunts/uncles, CVD mortality

\section{Key Messages}

- Offspring low birthweight (LBW) was associated with increased risk of CVD mortality in parents and in aunts/uncles.

- The established CVD risk factors contributed substantially to associations among family members with a known genetic link.

- Our findings suggest that associations between offspring BW and CVD in adult relatives involve both behavioural variables (especially smoking) and shared genetics relating to established CVD risk factors.

\section{Introduction}

A link between suboptimal fetal growth and a higher risk of cardiovascular disease (CVD) has been demonstrated within individuals in several populations. ${ }^{1-3}$ Some causal models have been proposed to define a mechanism underlying this association, including intrauterine programming by epigenetic mechanisms ${ }^{4}$ and common genetic factors influencing both fetal growth and adult diseases. ${ }^{5}$ Alternatively, behavioural/environmental factors may explain the low birthweight(LBW) and CVD risk association. ${ }^{6}$ The importance of both genetic and shared environmental factors has been emphasized in previous research. ${ }^{7-9}$ Some studies report stronger association in mothers than fathers, highlighting the importance of intrauterine factors. ${ }^{10,11}$ Moreover, a strong genetic correlation has been found in a genome-wide association study between birthweight (BW) and coronary artery disease, blood pressure and type 2 diabetes, suggesting that the association between BW and adult disease may partly be explained by shared genetic variants. ${ }^{12}$

Family studies have reported inverse relationships between offspring BW and CVD mortality in both parents and grandparents, which may implicate common genetic factors. ${ }^{13,14}$ As anticipated, maternal smoking during pregnancy was found to be a key confounding factor, ${ }^{15}$ suggesting genetic and non-genetic mechanisms in the intergenerational transmission of disease risk. ${ }^{9,16,17}$ However, it has been notoriously difficult to separate the contribution of common genetic factors from shared behavioural/socioeconomic circumstances within a nuclear family, because these potential influences are closely linked.

Investigating the offspring BW and CVD mortality association in extended family members such as aunts/uncles provides an alternative approach to studies investigating parental offspring associations. Offspring in principle share on average $50 \%$ of their genes with their parents, and they share on average $25 \%$ of their genes with their aunts and uncles. We assume that aunts/uncles in most cases belong to households different from their nieces/ nephews, and therefore are less likely to share environmental factors compared with the parents and their offspring.

The objective of this study employing data from the Norwegian Medical Birth Registry and Cause of Death Registry was to investigate if the association observed between offspring BW and parental CVD mortality can also be observed for aunts/uncles, and to explore to what extent these associations are explained by known CVD risk factors such as body mass index (BMI), blood pressure, total cholesterol and smoking. We hypothesized that if shared genes explain the BW and CVD association, we would expect a stronger offspring BW and CVD mortality association in parents than in aunts/uncles, and a similar pattern of association in all four classes of aunts/uncles.

\section{Methods}

A cohort was created by linking Norwegian data from cardiovascular health surveys, the Medical Birth Registry, the Cause of Death Registry, the Educational Registry and a multigenerational database containing information on familial relationships for the whole population of Norway. We included offspring (born between 1967 and 2012) with available information on their parents and at least one maternal and one paternal aunt/uncle. Aunts/uncles were defined as full siblings of a parent (sharing both mother and father). Offspring births with gestational age $<37$ / $>44$ weeks or BW $<1000 \mathrm{~g}$ were excluded. The final dataset comprised 1353956 births linked to parents and one maternal and one paternal aunt/ uncle (Figure 1). 

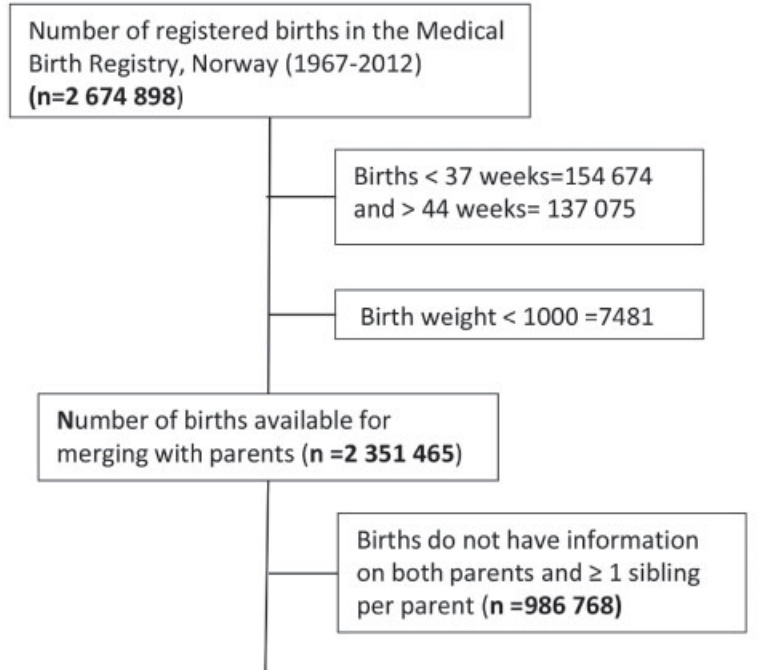

The total number of births linked with both parents (who each have $\geq 1$ sibling in the population register) ( $\mathrm{n}=\mathbf{1} 353 \mathbf{9 5 6}$ ) with parents and their siblings for which CVD risk factors data was available Mothers $(\mathbf{n}=\mathbf{3 1 8} 896)$

Maternal aunts/uncles ( $n=142$ 361)

Fathers $(n=319$ 844)

Paternal aunts/uncles ( $\mathbf{n = 1 4 5}$ 901)

Figure 1. Flow chart of the study population.

\section{Measures}

BW (in grams) was analysed as a continuous variable and according to categories of offspring BW for gestational age: small for gestational age (SGA), <10th percentile of the BW distribution; large for gestational age (LGA), >90th percentile of the BW distribution; and appropriate for gestational age (AGA), 10th-90th percentiles of BW distribution. ${ }^{18}$ Additional data were included for offspring (sex, year of birth and congenital anomalies coded as 'diseases in offspring' $)^{19}$ and for mothers [age, parity, smoking, diseases before pregnancy (asthma, chronic hypertension, chronic renal disease, urinary tract infection, rheumatoid arthritis, heart disease, diabetes, epilepsy and thyroid diseases), and diseases during pregnancy (vaginal bleeding, glycosuria, hypertension, preeclampsia, eclampsia, gestational diabetes, anaemia, thrombosis and infection]. These maternal and offspring factors could be important confounders for the relationship between $\mathrm{BW}$ and CVD mortality in parents. However, to make the analysis comparable between all relationships, we adjusted model 1 for mother's age at offspring birth in every association. Data on age at offspring's birth and the highest level of education ( $\leq 9$ years, $10-12$ years and $\geq 13$ years) completed by 2011 were included both for parents and for aunts/uncles.

Three large cardiovascular health surveys-the County Study, ${ }^{20}$ the Age 40 Program $^{21}$ and Cohort Norway $(\mathrm{CONOR})^{22}$-were conducted in Norway during 197488, 1985-99 and 1994-2003, respectively. CVD risk factor data-body mass index $\left(\mathrm{BMI} ; \mathrm{kg} / \mathrm{m}^{2}\right)$, total cholesterol (TC; $\mathrm{mmol} / \mathrm{L})$, triglycerides (TG; mmol/L), systolic and diastolic blood pressure (SBP and DBP; $\mathrm{mmHg}$ ), and smoking-from these health surveys were available in a subgroup (Figure 1). We used this subgroup to examine the role of traditional CVD risk factors on the association between offspring BW and CVD mortality in parents and in aunts/uncles. In the subgroup, follow-up was started from the date of CVD risk factors measurement in the population surveys.

\section{Outcome measure}

Cause of death was acquired from the Cause of Death Registry, Norway, using the International Classification of Diseases (ICD) 8th, 9th and 10th revisions. The primary outcome was mortality from CVD (ICD 8/9: 390-459, ICD-10: 100-199). Secondary outcomes were mortality from ischaemic heart disease (IHD) and from stroke (IHD: ICD 8/9: 410-414, ICD 10: 120-125, stroke: ICD 8/9: 430-438, ICD 10: 160-169).

\section{Statistical analysis}

Cox proportional hazard models were used to calculate the hazard ratio (HR) of deaths from CVD, IHD and stroke in parents and in aunts/uncles for a one standard deviation (SD) increase and categories of offspring BW (SGA and LGA with AGA as the reference). Parent's, aunt's/uncle's age was the time axis for the Cox model. Follow-up started at the date of offspring birth and continued up to the parent's/aunt's/uncle's emigration, death or end of the study (30 December 2014). The proportional hazards assumption was examined by plotting the Schoenfeld residuals and was not found to be violated by visual inspection. Total person -years included for the analysis were 30908031 (fathers), 31671408 (mothers), 29928884 (maternal siblings) and 30020262 (paternal siblings). Several offspring in our study were nested within the same parents, aunts/uncles. These offspring were clustered on their parents' and aunts'/uncles' identity, using the 'vce cluster' command in Stata. This command effectively adjusts the standard error for within-parents and within- 
aunts/uncles correlation. Some of the aunts/uncles appeared in the data more than once, as they could be the sibling of several mothers or fathers in the sample.

Modelling was carried out in three stages: Model 1 was adjusted for mother's age at offspring birth (continuous). Model 2 was additionally adjusted for offspring year of birth (continuous), maternal parity (coded as 0,1 or $\geq 2$ ) and maternal diseases before and during pregnancy [coded as 0 (no) or 1 (yes) and disease in offspring at birth (coded as 0 (no) or 1 (yes)]. Model 3 was additionally adjusted for the education of parents, aunts and uncles and marital status of the parents. In the subsample for which CVD risk factor data were accessible, the association between offspring BW and mortality from CVD, IHD and stroke in parents and in aunts/uncles was first adjusted for mother's age, which is comparable with Model 1 in the full dataset. The association was then additionally adjusted for CVD risk factors (BMI, TC, TG, SBP, DBP and smoking) and education of parents, aunts and uncles. To examine specificity of outcomes, whether the paternal association appears to reflect socioeconomic/behavioural confounding, we repeated our analysis with lung cancer mortality as outcome.

\section{Results}

Mean follow-up time $( \pm S D)$ for the parents and aunts/ uncles was $47 \pm 5$ years. Mean age (years) at the followup was $54 \pm 9.8$ (fathers), $52 \pm 9.7$ (mothers), $55 \pm$ 10.4 (maternal siblings), $56 \pm 10.7$ (paternal siblings). During follow-up, $0.29 \%$ of mothers and $1.20 \%$ of fathers died of CVD. The parents, aunts and uncles of the SGA offspring were comparatively younger and less educated than the other two groups. Maternal smoking during pregnancy was associated with lower offspring BW in the subgroup where these data were available. The maximum age of aunts and uncles at follow-up was 74 years. During follow-up, $0.55 \%$ of maternal aunts and $1.68 \%$ of maternal uncles died of CVD. The respective percentages for paternal aunts and uncles were $0.60 \%$ and $1.86 \%$ (Table 1).

\section{Parental mortality in relation to offspring BW}

An inverse association between offspring BW and ageadjusted mortality from CVD, IHD and stroke was observed among mothers and fathers, but was stronger among mothers (Table 2). For all separate causes of death, adding offspring year of birth, maternal parity, maternal 'disease before and during pregnancy' and 'disease in offspring' to the model minimally attenuated the associations in mothers and fathers (Model 2). The effect estimates for 1-SD increase in offspring BW were attenuated marginally in the parents when marital status and educational level were included in Model 3 (Table 2). The age-adjusted HR (95\% CI) for CVD mortality in mothers and fathers of SGA offspring compared with AGA offspring were 2.02 (1.85-2.21) and 1.33 (1.26-1.40), respectively. In LGA offspring a reduced hazard for CVD mortality was observed among mothers and fathers [HR for mothers, 0.74 (0.63-0.86); for fathers, $0.84(0.78-0.90)]$. For IHD and stroke mortality, similar trends in SGA and LGA offspring were observed in both parents (Table 3). We also analysed data according to the sex of the offspring. No difference in association was observed in either parent (Supplementary Table 1a and b, available as Supplementary data at IJE online).

\section{Aunts' and uncles' mortality in relation to niece/nephew BW}

Mortality from CVD and IHD was inversely associated with offspring BW for all four classes of aunts/uncles (Table 2). For stroke mortality, there was no strong evidence that the four classes of aunts/uncles differed from each other and, individually, there was evidence weakly suggesting a negative association for all four. The strength of association was smaller in all aunts /uncles than that observed among mothers. Mortality associations in aunts/ uncles were only slightly weaker than in the fathers (with largely overlapping CI). Adjustment for offspring year of birth, maternal parity, maternal diseases before and during pregnancy and disease in offspring (Model 2) minimally changed the hazard ratio for CVD and IHD mortality in all aunts/uncles. Estimates were attenuated a little in all four classes of aunts/uncles when their educational status was added as a covariate (Model 3). For CVD and IHD mortality, a higher hazard was observed in aunts/uncles of SGA offspring whereas a reduced hazard was noted in aunts/ uncles of LGA offspring. For stroke mortality, results were mostly in the same direction as for CVD and IHD, but considerably weaker, with $95 \%$ CI including the null (Table 3).

In the subsample with data on CVD risk factors, an inverse association between offspring BW and CVD mortality was noted among parents and among aunts/uncles. These results were roughly comparable to the age-adjusted results in the whole dataset (Tables 2 and 3). Adjustment for CVD risk factors attenuated the associations in all relationships substantially (Table 4, Figure 2), but additional adjustment for education made a small difference to estimates. For lung cancer mortality, the patterns of results observed in parents, aunts and uncles were similar to those observed for CVD mortality (Supplementary Table 2, available as Supplementary data at IJE online). 
Table 1. Characteristics of offspring, parents and aunts/uncles according to the categories of offspring birthweight

\begin{tabular}{|c|c|c|c|c|c|}
\hline & $\mathrm{SGA}^{\mathrm{a}}$ & $\mathrm{AGA}^{\mathrm{b}}$ & $\mathrm{LGA}^{\mathrm{c}}$ & Overall & $P$-value \\
\hline Offspring & $(n=135368)$ & $(n=1083163)$ & $(n=135425)$ & $(n=1353956)$ & \\
\hline Birthweight (grams) & $2.750 \pm 262$ & $3.592 \pm 335$ & $4.467 \pm 270$ & $3.596 \pm 501$ & $<0.001$ \\
\hline Male (\%) & $\begin{array}{c}132981 \\
(51.1)\end{array}$ & $\begin{array}{c}137383 \\
(51.2)\end{array}$ & $\begin{array}{c}139635 \\
(51.1)\end{array}$ & $\begin{array}{c}698589 \\
(51.1)\end{array}$ & 0.482 \\
\hline Gestational age (weeks) & $39.7 \pm 1.6$ & $39.9 \pm 1.4$ & $40.0 \pm 1.3$ & $39.9 \pm 1.3$ & $<0.001$ \\
\hline Congenital diseases & 3.8 & 3.0 & 3.3 & 3.1 & $<0.001$ \\
\hline Mothers & $(n=135368)$ & $(n=1083163)$ & $(n=135425)$ & $(n=1353956)$ & \\
\hline Age at offspring birth (years) & $26.4 \pm 5.3$ & $27.4 \pm 5.1$ & $28.7 \pm 5.0$ & $27.4 \pm 5.2$ & $<0.001$ \\
\hline Disease during pregnancy & 11.8 & 6.3 & 6.8 & 6.9 & $<0.001$ \\
\hline Diseases before pregnancy & 6.7 & 6.5 & 8.3 & 6.7 & $<0.001$ \\
\hline Education $>13$ years & 29.6 & 38.4 & 42.3 & 36.5 & $<0.001$ \\
\hline \multicolumn{6}{|l|}{ Mortality: } \\
\hline CVD & 0.59 & 0.27 & 0.17 & 0.29 & $<0.001$ \\
\hline IHD & 0.22 & 0.09 & 0.05 & 0.10 & $<0.001$ \\
\hline Stroke & 0.23 & 0.10 & 0.07 & 0.11 & $<0.001$ \\
\hline Smoking during pregnancy ${ }^{\mathrm{d}}$ & 28.0 & 17.1 & 12.7 & 17.3 & $<0.001$ \\
\hline Maternal aunts & $(n=62577)$ & $(n=499003)$ & $(n=62538)$ & $(n=624118)$ & \\
\hline Age at offspring birth (years) & $29.5 \pm 7.5$ & $30.4 \pm 7.4$ & $31.7 \pm 7.4$ & $30.5 \pm 7.4$ & 0.002 \\
\hline Education $>13$ years & 30.5 & 36.7 & 39.4 & 36.3 & $<0.001$ \\
\hline \multicolumn{6}{|l|}{ Mortality: } \\
\hline CVD & 0.72 & 0.54 & 0.47 & 0.55 & $<0.001$ \\
\hline IHD & 0.33 & 0.21 & 0.16 & 0.22 & $<0.001$ \\
\hline Stroke & 0.21 & 0.18 & 0.16 & 0.18 & $<0.001$ \\
\hline Maternal uncles & $(n=67201)$ & $(n=542436)$ & $(n=67691)$ & $(n=677328)$ & \\
\hline Age at offspring birth (years) & $29.7 \pm 7.5$ & $30.6 \pm 7.4$ & $31.6 \pm 7.4$ & $30.6 \pm 7.6$ & $<0.001$ \\
\hline Education $>13$ years & 24.9 & 29.6 & 30.9 & 29.3 & $<0.001$ \\
\hline \multicolumn{6}{|l|}{ Mortality: } \\
\hline CVD & 2.18 & 1.66 & 1.36 & 1.68 & $<0.001$ \\
\hline IHD & 1.35 & 0.97 & 0.79 & 0.99 & $<0.001$ \\
\hline Stroke & 0.35 & 0.28 & 0.20 & 0.28 & $<0.001$ \\
\hline Fathers & $(n=135368)$ & $(n=1083163)$ & $(n=135425)$ & $(n=1353956)$ & \\
\hline Age at offspring birth (years) & $29.6 \pm 5.7$ & $30.5 \pm 5.6$ & $31.7 \pm 5.5$ & $30.5 \pm 5.6$ & $<0.001$ \\
\hline Education $>13$ years & 24.8 & 31.3 & 33.4 & 30.8 & $<0.001$ \\
\hline \multicolumn{6}{|l|}{ Mortality: } \\
\hline CVD & 1.71 & 1.17 & 0.89 & 1.20 & $<0.001$ \\
\hline IHD & 0.74 & 1.08 & 0.55 & 0.75 & $<0.001$ \\
\hline Stroke & 0.28 & 0.17 & 0.12 & 0.17 & $<0.001$ \\
\hline Paternal aunts & $(n=64031)$ & $(n=515151)$ & $(n=65088)$ & $(n=644052)$ & \\
\hline Age at offspring birth (years) & $30.6 \pm 7.6$ & $31.3 \pm 7.7$ & $32.1 \pm 7.8$ & $31.3 \pm 7.7$ & 0.004 \\
\hline Education $>13$ years & 29.4 & 34.2 & 35.4 & 33.70 & $<0.001$ \\
\hline \multicolumn{6}{|l|}{ Mortality: } \\
\hline CVD & 0.92 & 0.57 & 0.45 & 0.60 & $<0.001$ \\
\hline IHD & 0.37 & 0.22 & 0.12 & 0.23 & $<0.001$ \\
\hline Stroke & 0.33 & 0.16 & 0.19 & 0.18 & $<0.001$ \\
\hline Paternal uncles & $(n=69867)$ & $(n=556695)$ & $(n=69679)$ & $(n=696241)$ & \\
\hline Age at offspring birth (years) & $30.6 \pm 7.6$ & $31.2 \pm 7.7$ & $32.1 \pm 7.9$ & $31.2 \pm 7.7$ & 0.043 \\
\hline Education $>13$ years & 24.9 & 28.1 & 28.4 & 27.9 & $<0.001$ \\
\hline \multicolumn{6}{|l|}{ Mortality: } \\
\hline CVD & 2.49 & 1.81 & 1.38 & 1.86 & $<0.001$ \\
\hline IHD & 1.58 & 1.06 & 0.81 & 1.11 & $<0.001$ \\
\hline Stroke & 0.32 & 0.30 & 0.31 & 0.30 & $<0.001$ \\
\hline
\end{tabular}

${ }^{\text {a }}$ GA (less than 10th percentile of offspring birthweight).

bAGA (10th-90th percentile of offspring birthweight).

${ }^{\mathrm{c}} \mathrm{LGA}$ (more than 90th percentile of offspring birthweight).

dinformation on smoking during pregnancy was available in 369844 mothers. $P$-value for continuous variables calculated by one-way ANOVA and for categorical variables by chi square test. Continuous variables are given as mean \pm SD and categorical variables are given as percentages. 
Table 2. Hazard ratio $(95 \% \mathrm{Cl})$ of deaths in parents and in aunts/uncles for 1-SD increase in offspring birthweight

\begin{tabular}{|c|c|c|c|c|}
\hline \multicolumn{5}{|c|}{ Hazard ratio $(95 \% \mathrm{CI})$} \\
\hline & Number of deaths & Model 1 & Model 2 & Model 3 \\
\hline \multicolumn{5}{|c|}{ Mothers $^{\mathrm{a}}$} \\
\hline CVD & 3875 & $0.72(0.69-0.75)$ & $0.74(0.71-0.78)$ & $0.77(0.74-0.80)$ \\
\hline IHD & 1351 & $0.69(0.64-0.74)$ & $0.72(0.67-0.77)$ & $0.75(0.70-0.81)$ \\
\hline Stroke & 1429 & $0.69(0.64-0.75)$ & $0.71(0.66-0.76)$ & $0.73(0.68-0.78)$ \\
\hline \multicolumn{5}{|c|}{ Maternal aunts ${ }^{\mathrm{a}}$} \\
\hline CVD & 3090 & $0.90(0.86-0.95)$ & $0.92(0.88-0.97)$ & $0.94(0.90-0.99)$ \\
\hline IHD & 1246 & $0.87(0.80-0.94)$ & $0.88(0.81-0.95)$ & $0.91(0.84-0.98)$ \\
\hline Stroke & 977 & $0.92(0.85-1.00)$ & $0.940 .86-1.03)$ & $0.96(0.88-1.05)$ \\
\hline \multicolumn{5}{|c|}{ Maternal uncles ${ }^{\mathrm{a}}$} \\
\hline CVD & 10359 & $0.91(0.88-0.93)$ & $0.92(0.90-0.95)$ & $0.94(0.91-0.96)$ \\
\hline IHD & 6250 & $0.88(0.85-0.91)$ & $0.90(0.87-0.93)$ & $0.92(0.89-0.95)$ \\
\hline Stroke & 1628 & $0.90(0.85-0.96)$ & $0.93(0.81-0.99)$ & $0.94(0.89-1.01)$ \\
\hline \multicolumn{5}{|c|}{ Fathers $^{\mathrm{a}}$} \\
\hline CVD & 16020 & $0.89(0.86-0.92)$ & $0.90(0.88-0.92)$ & $0.92(0.90-0.94)$ \\
\hline IHD & 10090 & $0.88(0.87-0.90)$ & $0.90(0.87-0.92)$ & $0.92(0.90-0.94)$ \\
\hline Stroke & 2338 & $0.84(0.80-0.89)$ & $0.86(0.81-0.91)$ & $0.88(0.83-0.93)$ \\
\hline \multicolumn{5}{|c|}{ Paternal aunts ${ }^{\mathrm{a}}$} \\
\hline CVD & 3768 & $0.91(0.88-0.95)$ & $0.92(0.89-0.96)$ & $0.95(0.91-0.98)$ \\
\hline IHD & 1437 & $0.91(0.86-0.97)$ & $0.92(0.86-0.98)$ & $0.94(0.88-1.01)$ \\
\hline Stroke & 1225 & $0.89(0.84-0.96)$ & $0.91(0.85-0.97)$ & $0.92(0.86-0.98)$ \\
\hline \multicolumn{5}{|c|}{ Paternal uncles ${ }^{\mathrm{a}}$} \\
\hline CVD & 12697 & $0.93(0.91-0.95)$ & $0.94(0.92-0.97)$ & $0.95(0.93-0.98)$ \\
\hline IHD & 7639 & $0.92(0.89-0.95)$ & $0.93(0.91-0.96)$ & $0.95(0.92-0.98)$ \\
\hline Stroke & 1835 & $0.96(0.90-1.02)$ & $0.97(0.91-1.03)$ & $0.98(0.92-1.05)$ \\
\hline
\end{tabular}

Model 1 was adjusted for maternal age at offspring birth. Model 2 was adjusted for Model 1 plus offspring year of birth, parity of mother, mother's diseases before and during pregnancy, diseases in offspring. Model 3 was adjusted for Models 1 and 2 plus parental marital status and education level in parents, aunts and uncles. $P$-value for difference in effect between mother's and father's mortality from CVD for 1-SD increase in offspring birthweight was $<0.001$. $P$-values for difference in effect between maternal aunts' and uncles' and between paternal aunts' and uncles' mortality from CVD for 1-SD increase in offspring birthweight were both $>0.37$.

${ }^{a}$ Number of offspring linked with parents ( $\left.n=1353956\right)$, maternal aunts $(n=624118)$, maternal uncles $(n=667328)$, paternal aunts $(n=644052)$, paternal uncles $(n=696241)$.

\section{Discussion}

We have shown an inverse association between offspring BW and mortality from CVD and IHD in parents and in their siblings (aunts/uncles). The association was stronger in mothers than in fathers or in aunts/uncles. There were no differences in the estimates among the four classes of aunts/uncles, and the associations among fathers were only slightly stronger than those in aunts/uncles. The associations were to a large extent explained by CVD risk factors.

\section{Comparison of results with previous studies and potential mechanisms}

The relationship between lower offspring BW and increased risk of CVD among parents and aunts/uncles may support a genetic basis for the association. The relationship observed in parents is consistent with previous studies including both mothers and fathers, ${ }^{23,24}$ and with studies indicating a stronger association in mothers than in fathers. ${ }^{14,25}$ In contrast, another study reported similar father-offspring and motheroffspring associations for cardiovascular risk factors. ${ }^{26}$ To our knowledge, the association between niece/nephew BW and CVD mortality in aunts/uncles has not previously been explored. Therefore, direct comparison of our results with other studies is not possible. However, a number of multigenerational studies, reporting a strong association between grandchild BW and mortality in grandparents, support a genetic influence on the association between BW and CVD. ${ }^{13-15}$

CVD has a substantial genetic component and several genes, particularly those encoding glucokinase, ${ }^{5}$ clotting factors ${ }^{27}$ and angiotensinogen, ${ }^{28}$ have mutations that are associated with both restricted fetal growth and risk of CVD. A recent study also confirmed genetic influence on the association between LBW and adult hypertension. ${ }^{29}$ Additionally, it has been proposed that shared environmental factors, such as smoking, diet and socioeconomic position (SEP), also may contribute to the negative association between $\mathrm{BW}$ and CVD risk. ${ }^{30}$ 
Table 3. Hazard ratio $(95 \% \mathrm{Cl})$ of deaths in parents and in aunts/ uncles according to the categories of offspring birthweight

\begin{tabular}{|c|c|c|c|c|c|c|c|c|}
\hline \multicolumn{9}{|c|}{ Hazard ratio $(95 \% \mathrm{CI})$} \\
\hline \multicolumn{4}{|c|}{ Model 1} & \multicolumn{2}{|c|}{ Model 2} & \multicolumn{3}{|c|}{ Model 3} \\
\hline & $\begin{array}{c}\text { Number of } \\
\text { deaths }\end{array}$ & $\mathrm{AGA}^{\mathrm{a}}$ & $\mathrm{SGA}^{\mathrm{b}}$ & $\mathrm{LGA}^{\mathrm{c}}$ & $\mathrm{SGA}^{\mathrm{b}}$ & $\mathrm{LGA}^{\mathrm{c}}$ & $\mathrm{SGA}^{\mathrm{b}}$ & $\mathrm{LGA}^{\mathrm{c}}$ \\
\hline \multicolumn{9}{|c|}{ Mothers $^{\mathrm{d}}$} \\
\hline CVD & 3875 & 1.00 & $2.02(1.85-2.21)$ & $0.74(0.63-0.86)$ & $1.87(1.71-2.05)$ & $0.76(0.65-0.88)$ & $1.74(1.59-1.91)$ & $0.80(0.69-0.93)$ \\
\hline IHD & 1351 & 1.00 & $2.18(1.88-2.53)$ & $0.65(0.49-0.86)$ & $1.99(1.72-2.30)$ & $0.66(0.50-0.88)$ & $1.81(1.57-2.10)$ & $0.70(0.52-0.92)$ \\
\hline Stroke & 1429 & 1.00 & $2.18(1.89-2.53)$ & $0.83(0.65-1.05)$ & $2.05(1.77-2.38)$ & $0.85(0.67-1.08)$ & $1.93(1.67-2.24)$ & $0.88(0.69-1.12)$ \\
\hline \multicolumn{9}{|c|}{ - } \\
\hline CVD & 3090 & 1.00 & $1.21(1.07-1.35)$ & $0.96(0.83-1.12)$ & $1.18(1.05-1.33)$ & $0.97(0.84-1.13)$ & $1.13(1.01-1.27)$ & $1.00(0.86-1.16)$ \\
\hline IHD & 1246 & 1.00 & $1.43(1.20-1.71)$ & $0.81(0.62-1.05)$ & $1.37(1.15-1.63)$ & $0.84(0.65-1.10)$ & $1.28(1.08-1.53)$ & $0.88(0.68-1.15)$ \\
\hline Stroke & 977 & 1.00 & $1.14(0.93-1.41)$ & $0.92(0.70-1.20)$ & $1.09(0.72-1.23)$ & $0.94(0.74-1.24)$ & $1.03(0.84-1.28)$ & $0.96(0.75-1.28)$ \\
\hline \multicolumn{9}{|c|}{ 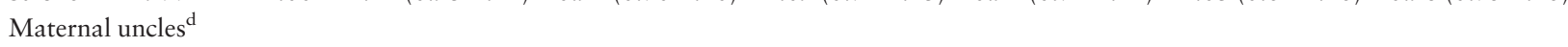 } \\
\hline CVD & 10359 & 1.00 & $1.18(1.10-1.26)$ & $0.92(0.84-1.00)$ & $1.15(1.08-1.25)$ & $0.94(0.86-1.02)$ & $1.11(1.04-1.19)$ & $0.95(0.88-1.04)$ \\
\hline IHD & 6250 & 1.00 & $1.30(1.19-1.42)$ & $0.86(0.77-0.96)$ & $1.23(1.13-1.35)$ & $0.90(0.80-1.01)$ & $1.18(1.08-1.29)$ & $0.91(0.82-1.02)$ \\
\hline Stroke & 1628 & 1.00 & $1.18(1.01-1.39)$ & $0.85(0.64-1.01)$ & $1.11(0.95-1.33)$ & $0.80(0.63-1.00)$ & $1.07(0.91-1.25)$ & $0.81(0.64-1.02)$ \\
\hline \multicolumn{9}{|c|}{; } \\
\hline CVD & 16020 & 1.00 & $1.33(1.26-1.40)$ & $0.84(0.78-0.90)$ & $1.25(1.19-1.32)$ & $0.88(0.82-0.95)$ & $1.19(1.13-1.26)$ & $0.91(0.85-0.97)$ \\
\hline IHD & 10090 & 1.00 & $1.33(1.25-1.42)$ & $0.84(0.77-0.92)$ & $1.26(1.18-1.35)$ & $0.88(0.80-0.96)$ & $1.20(1.12-1.27)$ & $0.90(0.82-0.98)$ \\
\hline Stroke & 2338 & 1.00 & $1.53(1.35-1.73)$ & $0.78(0.64-0.95)$ & $1.45(1.28-1.64)$ & $0.81(0.67-0.99)$ & $1.38(1.22-1.57)$ & $0.84(0.69-1.02)$ \\
\hline \multicolumn{9}{|c|}{ Paternal aunts ${ }^{\mathrm{d}}$} \\
\hline CVD & 3768 & 1.00 & $1.16(1.04-1.29)$ & $0.79(0.69-0.91)$ & $1.11(0.99-1.23)$ & $0.83(0.72-0.95)$ & $1.05(0.94-1.17)$ & $0.85(0.74-0.97)$ \\
\hline IHD & 1437 & 1.00 & $1.20(1.02-1.42)$ & $0.70(0.55-0.88)$ & $1.18(0.99-1.40)$ & $0.72(0.57-0.91)$ & $1.11(0.94-1.32)$ & $0.74(0.58-0.92)$ \\
\hline Stroke & 1225 & 1.00 & $1.16(0.96-1.40)$ & $0.85(0.68-1.07)$ & $1.14(0.94-1.38)$ & $0.88(0.70-1.10)$ & $1.10(0.91-1.33)$ & $0.89(0.71-1.12)$ \\
\hline \multicolumn{9}{|c|}{ 党 } \\
\hline CVD & 12697 & 1.00 & $1.18(1.07-1.21)$ & $0.87(0.81-0.94)$ & $1.11(1.04-1.18)$ & $0.91(0.84-0.98)$ & $1.08(1.02-1.15)$ & $0.92(0.86-1.00)$ \\
\hline IHD & 7639 & 1.00 & $1.22(1.04-1.21)$ & $0.94(0.84-1.01)$ & $1.16(1.07-1.25)$ & $0.93(0.85-1.03)$ & $1.12(1.04-1.21)$ & $0.94(0.86-1.04)$ \\
\hline Stroke & 1835 & 1.00 & $1.09(0.88-1.23)$ & $0.81(0.66-0.99)$ & $1.03(0.88-1.22)$ & $0.85(0.70-1.06)$ & $1.00(0.84-1.18)$ & $0.86(0.70-1.06)$ \\
\hline
\end{tabular}

Model 1 was adjusted for maternal age at offspring birth. Model 2 was adjusted for Model 1 plus offspring year of birth, parity of mother, mother's diseases before and during pregnancy, diseases in offspring. Model 3 was adjusted for Model 2 plus parental marital status and education level in parents, aunts and uncles.

${ }^{a}$ AGA (10th-90th percentile of the birthweight).

${ }^{b}$ SGA (less than 10th percentile of the birthweight).

${ }^{c}$ LGA (more than 90th percentile of the birthweight).

${ }^{\mathrm{d}}$ Number of offspring linked with parents $(n=1353956)$, maternal aunts $(n=624118)$, maternal uncles $(n=667328)$, paternal aunts $(n=644052)$, paternal uncles $(n=696241)$.

To investigate the significance of shared familial factors, we extended our analyses and assessed the role of CVD risk factors in the relationship. The attenuation of offspring BW and CVD mortality association in parents and in aunts/uncles after adjustment for CVD risk factors suggests a contribution of familial factors shared not only in a nuclear family, but also in extended families. The impact of CVD risk factors such as blood pressure, lipids and obesity may support a role of shared genes, as these factors are genetically influenced. ${ }^{31-33}$ However, the contribution of health-related behaviours such as smoking ${ }^{34}$ may indicate the importance of shared environmental factors in the association. Smoking behaviour has been linked to genetic variants, ${ }^{35}$ but there is little evidence on shared genetic factors linking smoking and LBW. Furthermore, a role of education in BW and CVD mortality association was observed in all familial relationships. Studies have shown a higher obesity and diabetes risk in parents of offspring with higher BWs. ${ }^{36-38}$ However, we observed an increased CVD mortality among parents of SGA offspring but not with LGA offspring. ${ }^{10,39,40}$ These may be two different mechanisms. It might be possible that parental diabetes/ obesity is more relevant to LGA offspring and CVD to SGA offspring.

Multiple potential mechanisms may explain the associations observed between offspring BW and CVD mortality in parents and aunts/uncles. Genetic confounding is one possible explanation, but for a purely genetic model we expect similar strength of associations in parents and half of this strength in aunts/uncles relationships. However, we found a stronger association in mothers than in fathers and aunts/uncles, suggesting that multiple potential 
Table 4. Hazard ratio $(95 \% \mathrm{Cl})$ of deaths in parents and in aunts/uncles according to offspring birthweight after adjusting for CVD risk factors and education. Subsample with CVD risk factors available

\begin{tabular}{|c|c|c|c|c|c|c|c|}
\hline \multicolumn{8}{|c|}{ Hazard ratio $(95 \% \mathrm{CI})$} \\
\hline & \multirow{2}{*}{$\begin{array}{c}\text { Number of } \\
\text { deaths }\end{array}$} & \multirow{2}{*}{$\begin{array}{l}\text { 1-SD increase in } \\
\text { offspring BW } \\
\text { Age-adjusted }^{\mathrm{c}}\end{array}$} & \multirow[b]{2}{*}{$\begin{array}{l}\text { Plus CVD risk } \\
\text { factors }^{\mathrm{d}}\end{array}$} & \multirow[b]{2}{*}{ Plus education $^{\mathrm{e}}$} & \multicolumn{2}{|c|}{$\mathrm{SGA}^{\mathrm{b}}$} & \multirow[b]{2}{*}{ Plus education $^{\mathrm{e}}$} \\
\hline & & & & & Age-adjusted ${ }^{c}$ & $\begin{array}{l}\text { Plus CVD risk } \\
\text { factors }^{\mathrm{d}}\end{array}$ & \\
\hline \multicolumn{8}{|c|}{ Mothers ${ }^{f}$} \\
\hline CVD & 1325 & $0.70(0.65-0.76)$ & $0.79(0.73-0.84)$ & $0.80(0.74-0.85)$ & $2.00(1.72-2.32)$ & $1.58(1.36-1.84)$ & $1.55(1.33-1.80)$ \\
\hline IHD & 480 & $0.71(0.63-0.79)$ & $0.81(0.72-0.90)$ & $0.82(0.73-0.91)$ & $1.99(1.57-2.53)$ & $1.50(1.18-1.91)$ & $1.46(1.15-1.85)$ \\
\hline Stroke & 493 & $0.65(0.57-0.73)$ & $0.74(0.65-0.83)$ & $0.74(0.66-0.84)$ & $2.22(1.74-2.83)$ & $1.76(1.38-2.24)$ & $1.72(1.35-2.19)$ \\
\hline \multicolumn{8}{|c|}{ Maternal aunts ${ }^{\mathrm{f}}$} \\
\hline CVD & 483 & $0.98(0.91-1.14)$ & $1.00(0.93-1.24)$ & $1.00(0.91-1.10)$ & $1.00(0.79-1.25)$ & $0.91(0.72-1.14)$ & $0.90(0.71-1.13)$ \\
\hline IHD & 291 & $1.00(0.86-1.33)$ & $1.00(0.91-1.35)$ & $1.02(0.92-1.37)$ & $1.22(0.70-2.12)$ & $1.43(0.81-1.30)$ & $1.42(0.81-1.47)$ \\
\hline Stroke & 162 & $1.00(0.82-1.26)$ & $1.01(0.86-1.19)$ & $1.02(0.87-1.20)$ & $0.87(0.55-1.37)$ & $0.77(0.49-1.22)$ & $0.76(0.48-1.20)$ \\
\hline \multicolumn{8}{|c|}{ Maternal uncles ${ }^{\mathrm{f}}$} \\
\hline CVD & 1268 & $0.90(0.84-0.97)$ & $0.94(0.87-1.01)$ & $0.94(0.88-1.01)$ & $1.19(1.01-1.43)$ & $1.09(0.91-1.31)$ & $1.08(0.90-1.30)$ \\
\hline IHD & 861 & $0.87(0.80-0.96)$ & $0.90(0.82-0.99)$ & $0.90(0.82-0.99)$ & $1.23(1.00-1.50)$ & $1.20(0.93-1.49)$ & $1.18(0.95-1.42)$ \\
\hline Stroke & 218 & $0.85(0.73-1.00)$ & $0.89(0.75-1.05)$ & $0.89(0.75-1.05)$ & $1.14(0.74-1.74)$ & $1.00(0.63-1.56)$ & $1.00(0.63-1.55)$ \\
\hline \multicolumn{8}{|c|}{ - } \\
\hline CVD & 4700 & $0.91(0.88-0.95)$ & $0.96(0.92-1.00)$ & $0.96(0.92-1.00)$ & $1.30(1.06-1.59)$ & $1.22(1.06-1.58)$ & $1.22(1.02-1.52)$ \\
\hline IHD & 3024 & $0.91(0.87-0.96)$ & $0.96(0.91-1.01)$ & $0.96(0.92-1.01)$ & $1.22(1.08-1.38)$ & $1.11(0.98-1.26)$ & $1.10(0.97-1.24)$ \\
\hline Stroke & 697 & $0.86(0.77-0.95)$ & $0.90(0.81-0.99)$ & $0.90(0.81-0.99)$ & $1.36(1.07-1.73)$ & $1.25(0.98-1.59)$ & $1.25(0.98-1.59)$ \\
\hline \multicolumn{8}{|c|}{, } \\
\hline CVD & 1055 & $0.85(0.78-0.92)$ & $0.86(0.78-0.93)$ & $0.86(0.79-0.93)$ & $1.21(1.09-1.33)$ & $1.10(1.00-1.22)$ & $1.09(0.99-1.21)$ \\
\hline IHD & 320 & $0.86(0.78-0.94)$ & $0.87(0.79-0.96)$ & $0.87(0.79-0.96)$ & $1.13(0.88-1.45)$ & $1.11(0.87-1.43)$ & $1.09(0.85-1.40)$ \\
\hline Stroke & 167 & $0.84(0.69-0.94)$ & $0.85(0.69-0.94)$ & $0.85(0.69-0.94)$ & $1.89(1.13-3.14)$ & $1.91(1.15-3.18)$ & $1.90(1.15-3.16)$ \\
\hline \multicolumn{8}{|c|}{ / } \\
\hline CVD & 1115 & $0.90(0.81-1.00)$ & $0.92(0.83-1.03)$ & $0.92(0.83-1.04)$ & $1.29(1.07-1.56)$ & $1.25(1.03-1.51)$ & $1.24(1.02-1.50)$ \\
\hline IHD & 716 & $0.88(0.81-0.96)$ & $0.90(0.83-0.98)$ & $0.91(0.83-0.98)$ & $1.32(1.03-1.68)$ & $1.27(0.99-1.62)$ & $1.25(0.98-1.60)$ \\
\hline Stroke & 170 & $0.84(0.68-1.04)$ & $0.85(0.69-1.06)$ & $0.86(0.69-1.06)$ & $1.40(0.91-2.16)$ & $1.36(0.88-2.10)$ & $1.35(0.86-2.08)$ \\
\hline
\end{tabular}

${ }^{\text {aBW }}$ (birthweight).

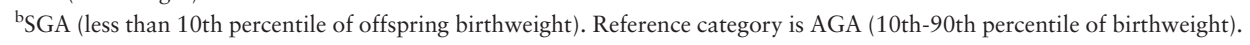

'Adjusted for mother's age.

${ }^{\mathrm{d}}$ CVD risk factors (BMI, cholesterol, triglycerides, systolic and diastolic blood pressure and current smoking(coded as yes/no).

${ }^{\mathrm{e}}$ Adjusted for mother's age, CVD risk factors and education.

${ }^{\mathrm{f}}$ Number of offspring linked with mothers $(\mathrm{n}=318$ 896), maternal aunts $(n=71727)$, maternal uncles $(n=70634)$, fathers $(n=319844)$, paternal aunts $(n=73420)$, paternal uncles $(n=72481)$.

mechanisms are involved in the mother-offspring association. First, intrauterine factors leading to LBW in offspring through malnutrition, poor placental growth and maternal pelvic restriction is one possibility. ${ }^{41-43}$ Second, a dual action of maternal genes, contributing to fetal growth both by gene inheritance and by affecting the intrauterine environment, could be another mechanism. ${ }^{44}$ Third, maternal health-related behaviours such as smoking may have a direct impact on offspring BW and the mother's own risk of CVD.

We expect the genetic association for fathers to be twice that for aunts/uncles, and presumably the environmental/ behavioural association would also be stronger. However, the associations in fathers were only a little stronger than those for aunts/uncles. This reflects that unobserved behavioural confounders, such as alcohol intake and physical activity, may be important in the paternal association. A similar trend of associations with lung cancer mortality also reflects the significance of behavioural confounders in the paternal association. Furthermore, the similar strength of associations with all classes of aunts/uncles is indicative of a genetic link. These associations may also be partly explained by environmental mechanisms, as parents and their siblings share similar home environments, dietary habits and health-related behaviours during early life. However, previous studies investigating offspring BW and parental sibling characteristics have suggested that maternal aunts but not uncles share important links with offspring BW. They propose that genetic effects from mothers are more important than paternal effects. ${ }^{45,46}$ 


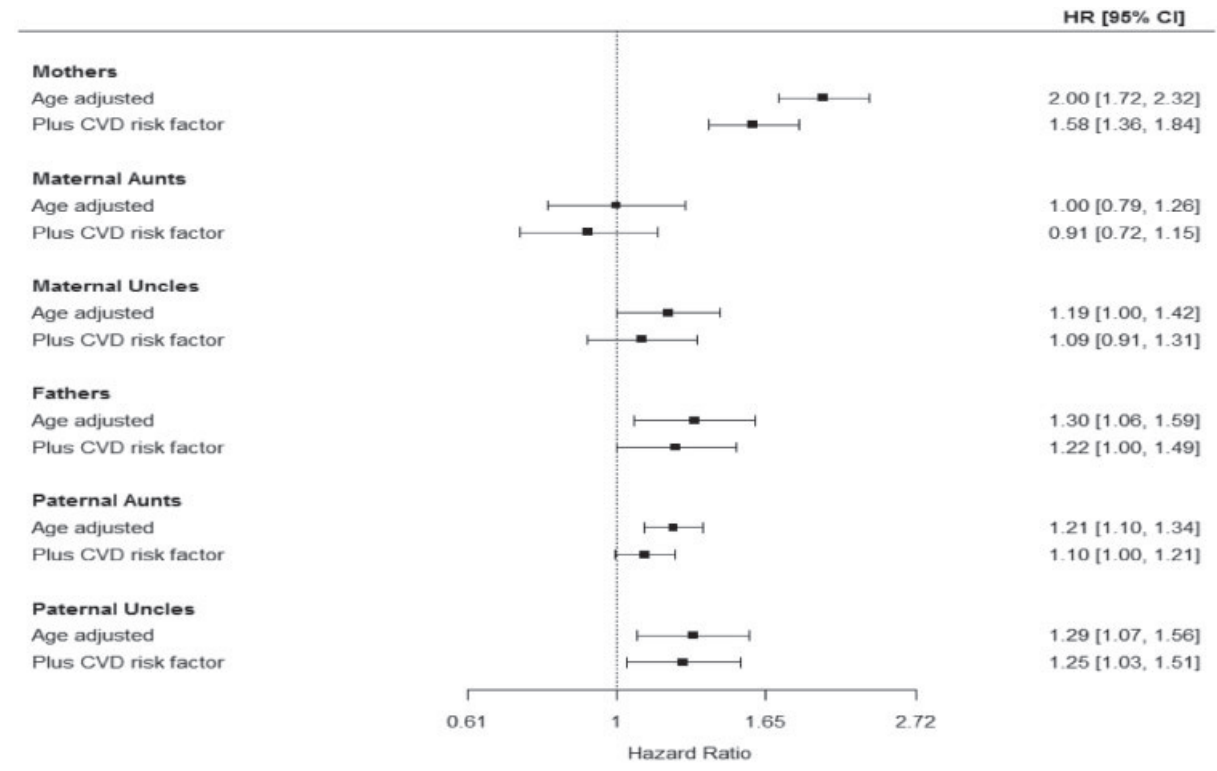

Figure 2. Hazard ratio (95\% Cl) of CVD deaths in mothers, fathers, aunts and uncles in small-for-gestational-age offspring after adjustment for CVD risk factors. Number of offspring linked with mothers $(n=318896)$, maternal aunts $(n=71727)$, maternal uncles $(n=70634)$, fathers $(n=319844)$, paternal aunts $(n=73420)$, paternal uncles $(n=72481)$.

A recent large-scale pedigree analysis suggests that assortative mating generates substantial apparent heritability with respect to mortality. ${ }^{47}$ Assortative mating might contribute to the mortality associations in our study. Another explanation could be the genetic nurturing phenomenon, suggesting that genetic and environmental mechanisms are interlinked and genetic effects can exert their impact through an environmentally mediated channel. ${ }^{48}$ The complete separation of environmental and genetic components that influence CVD mortality is difficult, and an interaction between these factors may further complicate our understanding.

\section{Strengths and weaknesses}

Our study is based on data from the nationwide registers, providing a large sample size and comprehensive population coverage. We established a dataset of offspring, parents and their siblings (aunts/uncles), which provides an opportunity to study the association between BW and CVD mortality in family members at different degrees of relatedness. The ability to include data on CVD risk factors adds novelty to the study. We also calculated BW for gestational age, which gives a precise measure of intrauterine fetal growth. Moreover, detailed information on maternal health before and during pregnancy was also included from the registry data. Diet and physical activity, which could be important in the relationship between BW and CVD mortality, were not included in our study. Education level was included as an indicator of SEP. The data on smoking in pregnancy were collected in the Medical Birth
Registry from 1998 onwards. Thus, only a few participants with short follow-up have this information, and the effect of smoking during pregnancy cannot be estimated.

\section{Conclusion}

We show that offspring BW was associated with increased risk of CVD in parents and in aunts/uncles, and that established CVD risk factors contributed substantially to associations among family members with a known genetic link. This suggests that both behavioural factors, especially smoking, and shared genetic factors in extended family members, involving these established CVD risk factors, play roles in the associations.

\section{Supplementary Data}

Supplementary data are available at IJE online.

\section{Funding}

This work was supported by a grant from the University of Oslo, Norway. D.C and G.D.S work in a unit funded by the UK Medical Research Council [MC_UU_00011/1] and the University of Bristol.

\section{Acknowledgments}

$\varnothing . N$. had the original idea and undertook the record linkage of the siblings. F.S. analysed the data and interpreted the results. All authors were involved in critical evaluation of the draft and approved the final version. Ethical approval for this study was obtained from the Regional Ethical Committee, Norway. Following 
cohorts from the CONOR were used in the analyses: The Tromsø Study (IV and V), Troms and Finnmark Health Study, NordTrøndelag Health Study (HUNT), Oslo Health Study, Oppland and Hedmark Health Study (OPPHED) and Hordaland Health Study (HUSK).

Conflict of interest: None declared.

\section{References}

1. Barker DJ, Winter PD, Osmond C, Margetts B, Simmonds SJ. Weight in infancy and death from ischaemic heart disease. Lancet 1989;2:577-80.

2. Barker DJ, Bagby SP. Developmental antecedents of cardiovascular disease: a historical perspective. J Am Soc Nephrol 2005; 16:2537-44.

3. Waterland RA, Michels KB. Epigenetic epidemiology of the developmental origins hypothesis. Annu Rev Nutr 2007;27: 363-88.

4. Hales CN, Barker D. The thrifty phenotype hypothesisType 2 diabetes. Br Med Bull 2001;60:5-20.

5. Hattersley AT, Tooke JE. The fetal insulin hypothesis: an alternative explanation of the association of low birthweight with diabetes and vascular disease. Lancet 1999;353:1789-92.

6. Bergvall N, Cnattingius S. Familial (shared environmental and genetic) factors and the fetal origins of cardiovascular diseases and type 2 diabetes: a review of the literature. J Intern Med 2008;264:205-23.

7. Ben-Shlomo Y, Kuh D. A life course approach to chronic disease epidemiology: conceptual models, empirical challenges and interdisciplinary perspectives. Int J Epidemiol 2002;31:285-93.

8. Hübinette A, Cnattingius S, Ekbom A, de Faire U, Kramer M, Lichtenstein P. Birthweight, early environment, and genetics: a study of twins discordant for acute myocardial infarction. Lancet 2001;357:1997-2001.

9. Drake AJ, Walker BR. The intergenerational effects of fetal programming: non-genomic mechanisms for the inheritance of low birthweight and cardiovascular risk. J Endocrinol 2004;180: $1-16$.

10. Davey Smith G, Hart C, Ferrell C. Birthweight of offspring and mortality in the Renfrew and Paisley study: prospective observational study. BMJ 1997;315:1189-93.

11. Davey Smith G, Harding S, Rosato M. Relation between infants' birthweight and mothers' mortality: prospective observational study. BMJ 2000;320:839-40.

12. Horikoshi M, Beaumont RN, Day FR et al. Genome-wide associations for birthweight and correlations with adult disease. Nature 2016;538:248.

13. Smith GC, Wood AM, White IR, Pell JP, Hattie J. Birthweight and the risk of cardiovascular disease in the maternal grandparents. Am J Epidemiol 2010;171:736-44.

14. Naess O, Stoltenberg C, Hoff DA et al. Cardiovascular mortality in relation to birthweight of children and grandchildren in 500, 000 Norwegian families. Eur Heart J 2013;34:3427-36.

15. McCarron P, Davey Smith G, Hattersley AT. Type 2 diabetes in grandparents and birthweight in offspring and grandchildren in the ALSPAC study. J Epidemiol Community Health 2004;58:517-22.

16. Drake AJ, Liu L. Intergenerational transmission of programmed effects: public health consequences. Trends Endocrinol Metab 2010;21:206-13.
17. Gluckman PD, Hanson MA, Beedle AS. Non-genomic transgenerational inheritance of disease risk. BioEssays 2007;29: $145-54$.

18. Chiavaroli V, Marcovecchio ML, de Giorgis T, Diesse L, Chiarelli F, Mohn A. Progression of cardio-metabolic risk factors in subjects born small and large for gestational age. PLoS One 2014;9:e104278.

19. Irgens LM. The Medical Birth Registry of Norway. Epidemiological research and surveillance throughout 30 years. Acta Obstet Gynecol Scand 2000;79:435-39.

20. Bjartveit K, Foss OP, Gjervig T, Lund-Larsen PG. The cardiovascular disease study in Norwegian counties. Background and organization. Acta Med Scand Suppl 1979;634:1-70.

21. Bjartveit K, Stensvold I, Lund-Larsen PG, Gjervig T, Kruger O, Urdal P. [Cardiovascular screenings in Norwegian counties. Background and implementation. Status of risk pattern during the period 1986-90 among persons aged 40-42 years in 14 counties]. Tidsskrift for Den Norske Laegeforening: tidsskrift for Praktisk Medicin, ny Raekke 1991;111:2063-72.

22. Naess O, Sogaard AJ, Arnesen E et al. Cohort Profile: Cohort of Norway (CONOR). Int J Epidemiol 2008;37:481-85.

23. Davey Smith G, Whitley E, Gissler M, Hemminki E. Birth dimensions of offspring, premature birth, and the mortality of mothers. Lancet 2000;356:2066-67.

24. Smith GCS, Pell JP, Walsh D. Pregnancy complications and maternal risk of ischaemic heart disease: a retrospective cohort study of 129290 births. Lancet 2001;357:2002-06.

25. Davey Smith G, Hypponen E, Power C, Lawlor DA. Offspring birthweight and parental mortality: prospective observational study and meta-analysis. Am J Epidemiol 2007; 166:160-69.

26. Vik KL, Romundstad P, Carslake D, Davey Smith G, Nilsen T. Comparison of father-offspring and mother-offspring associations of cardiovascular risk factors: family linkage within the population-based HUNT Study, Norway. Int J Epidemiol 2014; 43:760-71.

27. Kupferminc MJ, Eldor A, Steinman $\mathrm{N}$ et al. Increased frequency of genetic thrombophilia in women with complications of pregnancy. N Engl J Med 1999;340:9-13.

28. Zhang XQ, Varner M, Dizon-Townson D, Song F, Ward K. A molecular variant of angiotensinogen is associated with idiopathic intrauterine growth restriction. Obstetr Gynecol 2003; 101:237-42.

29. Warrington NM, Beaumont RN, Horikoshi M et al. Maternal and fetal genetic effects on birthweight and their relevance to cardio-metabolic risk factors. Nat Genet 2019;51:804-14.

30. Kivimaki M, Lawlor DA, Davey Smith G et al. Substantial intergenerational increases in body mass index are not explained by the fetal overnutrition hypothesis: the Cardiovascular Risk in Young Finns Study. Am J Clin Nutr 2007;86:1509-14.

31. Garrison RJ, Castelli WP, Feinleib M et al. The association of total cholesterol, triglycerides and plasma lipoprotein cholesterol levels in first degree relatives and spouse pairs. Am J Epidemiol 1979;110:313-21.

32. Harrap SB, Stebbing M, Hopper JL, Hoang HN, Giles GG. Familial patterns of covariation for cardiovascular risk factors in adults: The Victorian Family Heart Study. Am J Epidemiol 2000;152:704-15. 
33. An P, Rice T, Gagnon $\mathrm{J}$ et al. Familial aggregation of resting blood pressure and heart rate in a sedentary population. The heritage family study. Am J Hypertens 1999;12:264-70.

34. Huxley R. Smoking, birthweight, and mortality across generations. Eur Heart J 2013;34:3398-99.

35. Loukola A, Hällfors J, Korhonen T, Kaprio J. Genetics and smoking. Curr Addict Rep 2014;1:75-82.

36. Kong L, Nilsson IAK, Gissler M, Lavebratt C. Associations of maternal diabetes and body mass index with offspring birthweight and prematurity. JAMA Pediatr 2019;173:371-78.

37. Li C-Y, Sung F-C, Hsieh P-C, Lee M-D, Lu T-H, Chen H-F. Offspring birthweight and risk of mortality from diabetes in mothers. J Epidemiol Commun Health 2011;65:775-79.

38. Tyrrell JS, Yaghootkar H, Freathy RM, Hattersley AT, Frayling TM. Parental diabetes and birthweight in 236030 individuals in the UK Biobank Study. Int J Epidemiol 2013;42:1714-23.

39. Morken NH, Halland F, DeRoo LA, Wilcox AJ, Skjaerven R. Offspring birthweight by gestational age and parental cardiovascular mortality: a population-based cohort study. BJOG 2018; 125:336-41.

40. Davey Smith G, Sterne J, Tynelius P, Lawlor DA, Rasmusser F. Birthweight of offspring and subsequent cardiovascular mortality of the parents. Epidemiology 2005;16:563-69.
41. Martyn CN, Barker DJ, Osmond C. Mothers' pelvic size, fetal growth, and death from stroke and coronary heart disease in men in the UK. Lancet 1996;348:1264-68.

42. Bukowski R, Davis KE, Wilson P. Delivery of a small for gestational age infant and greater maternal risk of ischemic heart disease. PLoS One 2012;7:e33047.

43. Ramakrishnan U, Martorell R, Schroeder DG, Flores R. Role of intergenerational effects on linear growth. J Nutr 1999;129: $544 \mathrm{~s}-49 \mathrm{~s}$.

44. Manor O, Koupil I. Birthweight of infants and mortality in their parents and grandparents: the Uppsala Birth Cohort Study. Int J Epidemiol 2010;39:1264-76.

45. Ounsted M, Scott A, Ounsted C. Transmission through the female line of a mechanism constraining human fetal growth $\uparrow$. Int J Epidemiol 2008;37:245-50.

46. Cnattingius S. Commentary: On 'Transmission through the female line of a mechanism constraining human fetal growth'does it exist? Int J Epidemiol 2008;37:250.

47. Ruby JG, Wright KM, Rand KA et al. Estimates of the heritability of human longevity are substantially inflated due to assortative mating. Genetics 2018;210:1109-24.

48. Kong A, Thorleifsson G, Frigge ML et al. The nature of nurture: Effects of parental genotypes. Science 2018;359:424-28. 



\section{APPENDIX}

ANTENATAL FORM (1967-2012) - THE MEDICAL BIRTH REGISTRY OF NORWAY 



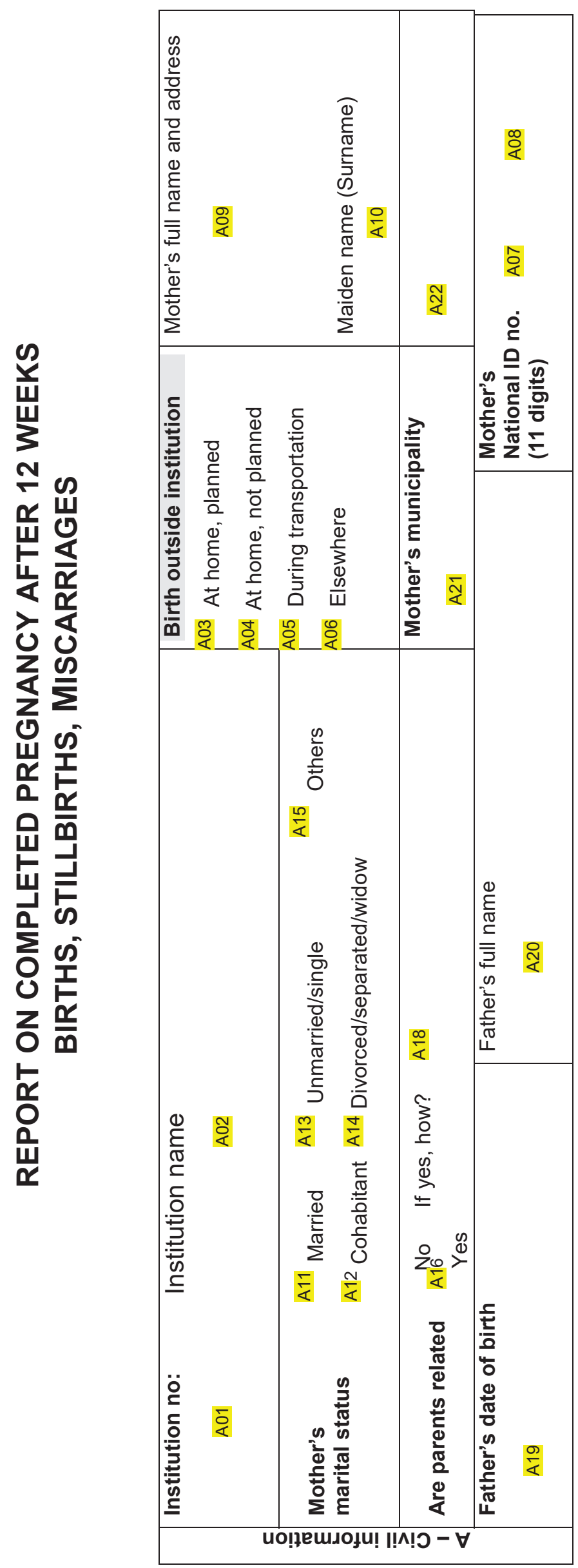

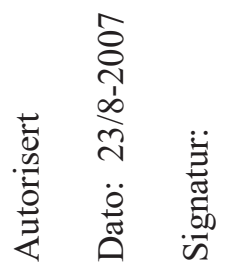




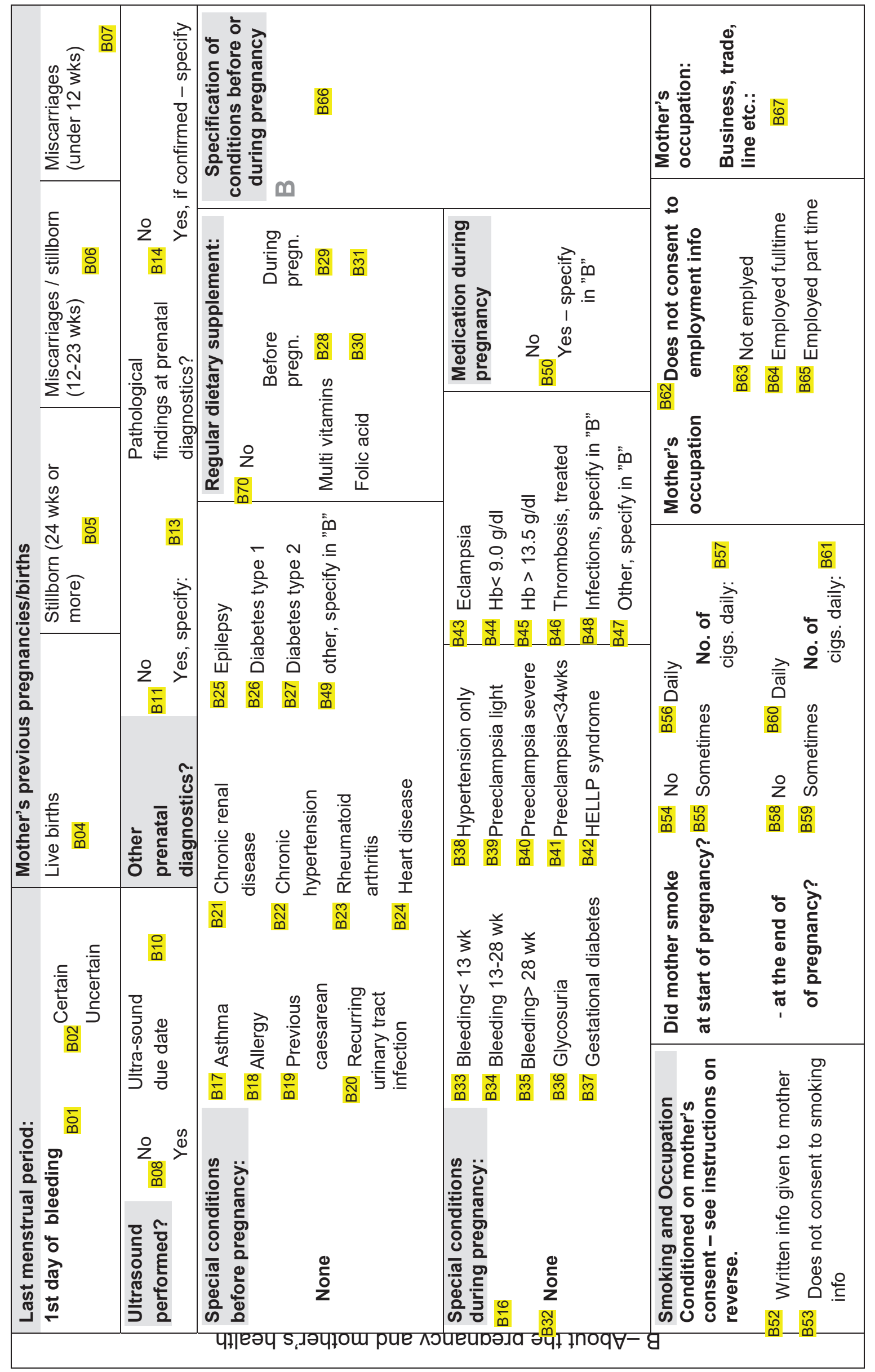

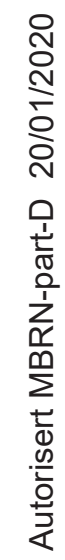




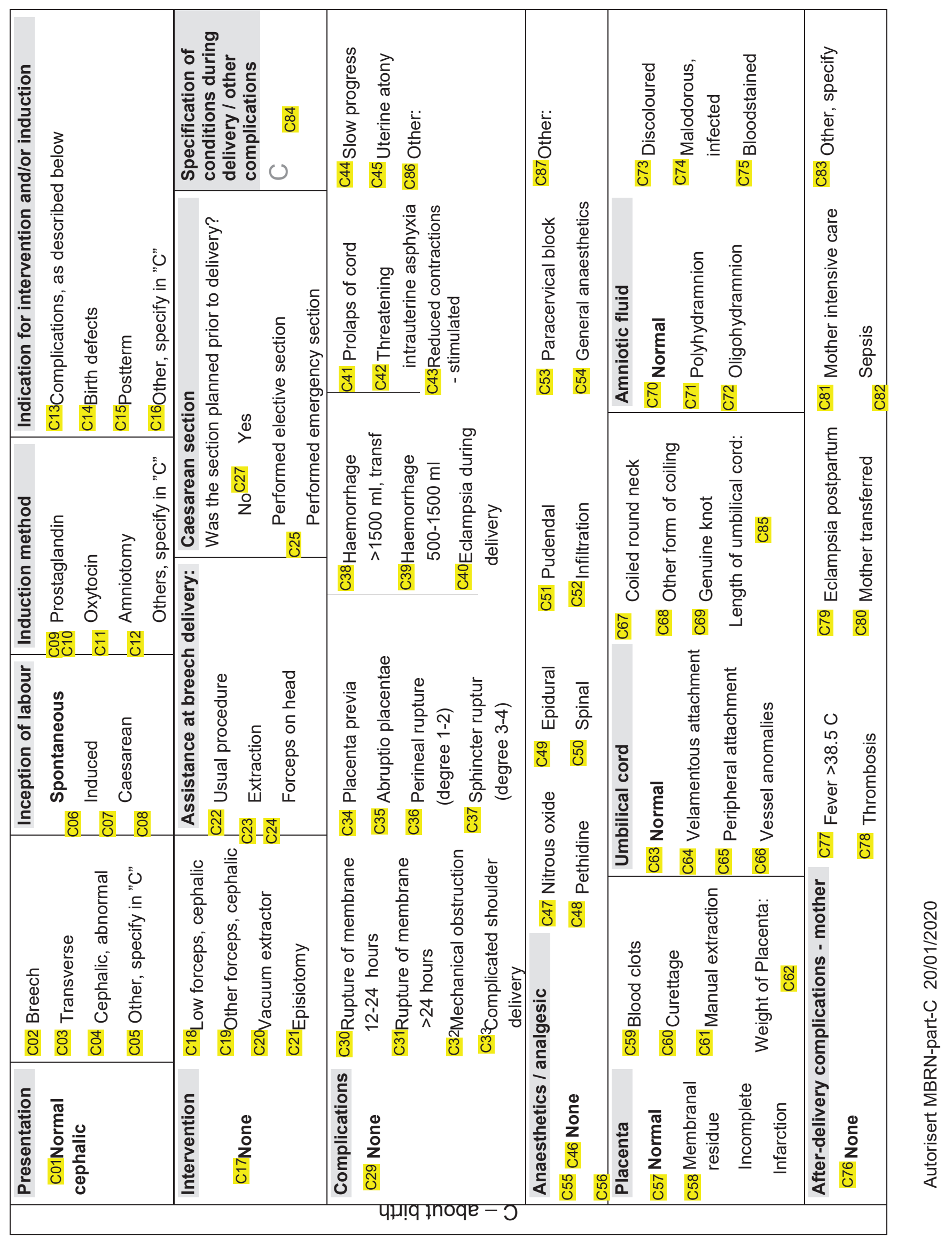




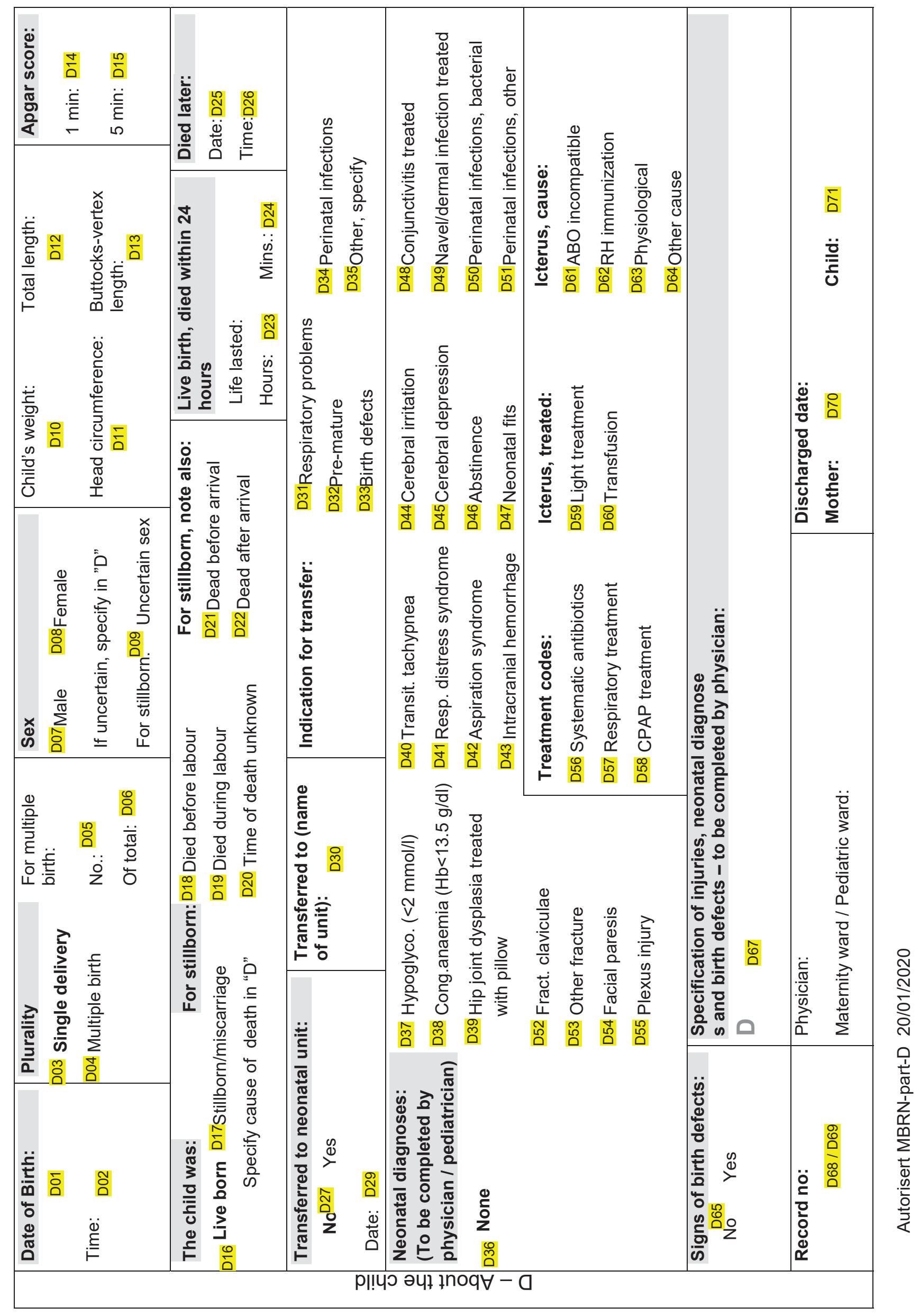



THE AGE 40 PROGRAM - QUESTIONNAIRE 



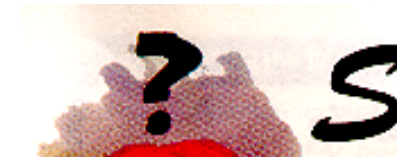

pø̆rreskjemaet er en viktig del av helseundersøkelsen. Vennligst fyll ut skjemaet på forhånd og ta det med til helseunder søkelsen. Dersom enkelte spørsmål er uklare, lar du dem stå ubesvart til du møter fram, og drøfter dem med personalet som gjennomfører undersqkelsen. Alle svar vil bli behandlet strengt fortrolig.

Det uffylte skjemaet vil bli lest av en maskin. Bruk blå eller sort farge ved utfylling. Det er viktig at du gảr fram slik:

- i de små boksene setter du kryss for det svaret som passer best for deg

- i de store boksene skriver du tall eller blokkbokstaver - NB! innenfor rammen for boksen.

Exsempler:

Avkryssing: $\mathbf{X}$
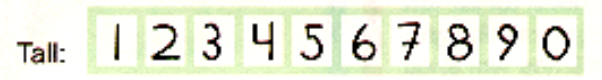

Bokstaver:

$A B C$

Statend helscunderdskelser $\vee$ Kannmenehetsenesten

\section{EGEN HELSE}

Hvordan er helsen din ná? (Sett bare ett kryss)

Darlig Ikke helt god God

Har du, eller har du hatt:

Fàr du smerter eller ubehag i brystet nár du:

JA NEI

Găr i bakker, trapper eller fort på flat mark?

$T$

Hvis du fár slike smerter, pleier du da â:

Stoppe? Saktne farten? Fortsette i samme takt?

Dersom du stopper, forsvinner smertene da JA NE etter mindre enn 10 minutter?

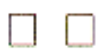

Kan slike smerter like gjerne opptre mens du er i ro?

\section{HVORLEDES FØLER DU DEG?}

Har du de siste to ukene følt deg:

\begin{tabular}{|c|c|c|c|c|}
\hline & $\mathrm{Nel}$ & Litt & $\begin{array}{c}\text { Engod } \\
\text { del }\end{array}$ & $\begin{array}{c}\text { Svar } \\
\text { mye }\end{array}$ \\
\hline Nervøs og urolig? ............. & & & & \\
\hline Plaget av angst?.............. & & & & \\
\hline Trygg $\circ g$ rolig?................... & & & 工 & L \\
\hline Irritabel? ............................ & & & & $\square$ \\
\hline Glad og optimistisk? ......... & & & & \\
\hline Nedforideprimert? ............ & [ & L & L & - \\
\hline 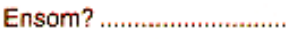 & L & 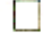 & L & L \\
\hline & 1 & 2 & 3 & 4 \\
\hline
\end{tabular}

\section{SYKDOM I FAMILIEN}

Har en eller flere ay foreldre eller søsken hatt hjerteinfarkt (sấr pá hjertet) eller angina pectoris (hjertekrampe)?

Har en eller flere foreldre/sasken hatt:

Hjerteinfarkt for de fylte 60 ăr?..

Hjerneslagihjernebledning før de fylte 70 âr?

\section{MUSKEL/SKJELETT-PLAGER}

Har du i løpet av det siste áret vært plaget med

smerter og/eller stivhet i muskler og ledd som

har vart i minst 3 måneder sammenhengende?..

Hvis NEI, gấ til aysnitt 5. SOSIALE FORHOLD.

Hvis JA, svar pa folgende:

Hvor har du hatt disse plagene?

Nakke

Skuldre (aksler)

Albuer...

Hândleddihender.

Bryst, mage

Øvre del av ryggen.

Korsryggen.

Hofter.

Knær.

Ankler, føtter

Hvor lenge har plagene vart sammenhengende?

Svar for det omrâdet hvor plagene har vart lengst.

Hvis under $1 \mathrm{adr}$ oppgi antall mnd.

Antall mnd.

Hvis 1 ấr eller mer, oppgi antall âr . Antall ar

Har plagene redusert din arbeidsevne det siste áret? Gjelder ogsá hjemmearbeidende. Sett bare ett kryss.

Nei/ubetydelig I noen grad I betydelig grad Vet Ikke

$\square_{1} \quad \square_{2} \quad \square_{3}^{3} \quad \square_{4}$

Har du vært sykmeldt pga. disse JA NEI lkke i

plagene det siste ấret?

Har plagene ført til redusert aktivitet i fritida? ........

\section{SOSIALE FORHOLD}

Mottar du nă noen av folgende ytelser?

Syketrygd (sykmeldt)...

Attføringspenger

Uførepensjon (hel eller delvis)

Arbeidsledighetstrygd.

Er husarbeid i hjemmet hovedyrket ditt?

(Svar NEl hvis lønnet arbejd utenom

JA NEI

husarbejd er 18 timer eller mer pr. whe). 


\section{UTDANNING}

Hvilken utdanning er den høyeste du har fullført?

Sett bare ett kryss.

Mindre enn 7 ár grunnskole

Grunnskole 7-10 ár, framhaldsskole,

folkehøgskole.

Realskole, middelskole, yrkesskole

1-2 ărig videregàende skole

Artium, ek.gymnas, allmennfaglig retning

i videregáende skole

Hogskole/universitet, 4 Ár eller mer

\section{KOST}

Hvor ofte bruker du disse matvarene?

Sett kryss i de rutene som beskriver ditt forbruk best.

\begin{tabular}{|c|c|c|c|c|}
\hline $\begin{array}{l}\text { Flare g. } \\
\text { thigig }\end{array}$ & Dagio & $\begin{array}{l}1-50 . \\
\text { pribs: }\end{array}$ & $\begin{array}{l}130 \\
\text { crontid }\end{array}$ & $\begin{array}{l}\text { Siflden } \\
\text { Ellaridon }\end{array}$ \\
\hline Fisk (middag, pálegg) ..... & & & & \\
\hline Frukt/grant..................... & & & & \\
\hline Helmelk, kefir, yoghurt... & & & & \\
\hline Lettmelk, lettyoghurt .... & & & $\square$ & \\
\hline Skummet melk (surisøt).. & & & & \\
\hline
\end{tabular}

Hva slags smor eller margarin bruker du

vanligvis PÁ BRODET?

Sett kryss i den ruta som passer best.

Bruker ikke smør/margarin ............................................... $\square$,

Meierismar

Hard margarin ............................................................... $\quad \square 3$

Blot (soft) margarin ...................................................... $\square$

Smør/margarin blanding ................................................ $\square$

Lettmargarinhiettsmør (Brelett)....................................... $\square 6$

Hva slags fett bruker du/dere vanligvis TIL MATLAGING? SeIt kryss iden ruta som passer best.

Smørimargarin................................................................... $\square$

Myk (soft) margariniolje............................................... $\square 2$

Bare olje ... $\square 3$

Vet ikke

\section{KAFFE/TE/ALKOHOL}

Hvor mange kopper kaffe/te drikker du daglig?

Sett $O$ hvis du ikke drikker kaffe/te daglig.

Antall kopper daglig

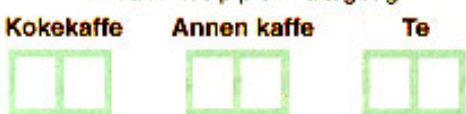

JA NEI

Er du total avholdsmannf-kvinne?

Hvor mange ganger I måneden drikker du

vanligvis alkohol? Regn ikke med lettol.

Sett 0 hvis mindre enn 1 gang i mnd. .............Antall ganger

Hvor mange glass øl, vin eller brennevin

drikker du VANLIGVIS I lopet av to uker?

Regn ikke med leftel. Sett o hvis du ikke drikker alkohol.

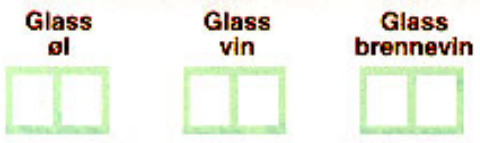

\section{RøYKING}

Hvor lenge er du vanligvis daglig

tilstede i røykfylt rom?............................... Antall hele timer

Sett O hvis du jkke oppholder deg i roykfylt rom.

Røyker du selv:

Sigaretter daglig?

Sigarerisigarillos daglig?

Pipe daglig?

Aldri røykt daglig

(Sett kryss)

Hvis du har roykt daglig tidligere, hvor

lenge er det siden du sluttet? Antall âr

Hvis du royker daglig ná eller har røykt tidligere:

Hvor mange sigaretter royker eller røykte du vanligvis daglig?.

Antall sigaretter

Hvor gammel var du da du begynte å

royke daglig? Alderiâr

Hwor mange àr til sammen har du roykt daglig? .

Antall ắ

\section{MOSJON}

Hvordan har din fysiske aktivitet i fritiden vært

det siste áret?

Tenk deg et ukentlig gjennomsnitt for áret.

Arbeiosvei regnes som fritid. Besvar begge sporsmålene.

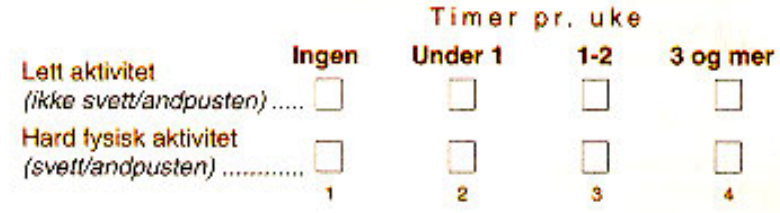

Bevegelse og kroppslig anstrengelse I din fritid. Hvis aktiviteten varierer meget f.eks. mellom sommer og vinter, sá ta et gjennomsnitt. Sporsmálet gjelder bare det siste âret.

Sett kryss i den ruta som passer best.

Leser, ser pá fjernsyn eller annen

stillesittende beskjeftigelse?

Spaserer, sykler eller beveger deg pă

annen măte minst 4 timer $i$ uka? ....

(Her skal du ogsá regne med gang eller

sykling til arbeidsstedet, søndagsturer m.m.)

Driver mosjonsidrett, tyngre hagearbeid e.l.? ....

(Merk at aktiviteten skal vare minst 4 timer i uka)

Trener hardt eller driver konkurranseidrett

regelmessig og flere ganger i uka? ....

$\square 4$

11. ENDRING AV HELSEVANER

Dette gjelder din interesse

for á endre helsevaner.

Roykesporsmalet besvares

Spise

Trimme Slutte

bare av dem som noyker.

sunnere mer å royke

Har du de siste 12 mnd. forsøkt á:

JA NEI JA NEI JA NEI

Om 5 år, tror du at du har

endret vaner pá noen av

JA NEI JA NEI JA NEI

disse omrádene?

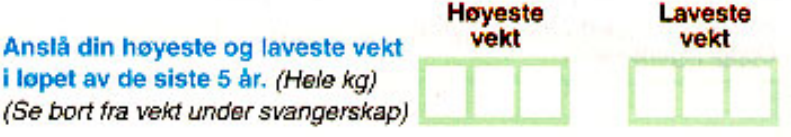


12. MEDISIN MOT HØYT BLODTRYKK

Bruker du medisin mot høyt blodtrykk?

Ná Fer, men ikke ná Aldri brukt

$\square_{1} \square_{2} \quad \square 3$

Hvis du bruker medisin ná, hvilke(t) merke(r) bruker du?

ikke skriv i disse rutene

\section{MEDISIN MOT HOYT KOLESTEROL}

Bruker du kolesterolsenkende medisiner NÂ?

Hvis NEI, gâ til 14. ETTERUNDERSøKELSE.

Hvor gammel var du da du begynte med

kolesterolsenkende medisiner?

Hvis du bruker kolesterolsenkende medisiner, hva

var grunnen til at du begynte med slik medisin?

(Sett kryss i de rutene som passer for deg.)

Hjerteinfarkt

Angina pectoris (hjertekrampe, brystkrampe)

Høy1 innhold av kolesterol i blodet

Hjertesykdom i familien (toreldre, søsken).

Hjemeslag'hjerneblødning/ «drypp"

Därlig blodsirkulasjon i bena

(areforkalkning, wroykebenw)

Andre ársaker

Skriv hvilke ấrsaker her:

ikke skriv i disse rutene

$\perp$

JA NEI

Jeg er usikker pả ấrsaken

Hvilke kolesterolsenkende medisiner bruker du NÅ og hvilken dose bruker du?

Hvilke(t) merke(r) bruker du?

lkke skriv i disse rutene

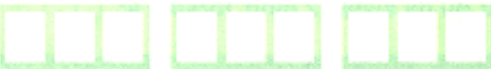

\section{ETTERUNDERSøKELSE}

Hvis denne helseundersøkelsen viser at du bør undersøkes nærmere, hvilken allmennpraktiserende lege/kommunelege onsker du da á bli henvist til?

Oppgi legens navn:

Ikke skriv i disse rutene UNDERS $\sigma K E L S E N$

Hvor gammel var du da du fikk menstruasjon

aller første gang?

Alder i àr

Har du for tiden regelmessig menstruasjon?

Regn den for regelmessig hvis den ikke har vært

borte mer enn 3 mnd. sammenhengende siste ar..

Til deg som svarte JA: Omtrent hvor mange

dager etter starten pá siste menstruasjon

skjer helseundersokelsen? (Sett bare ett kryss)

Under $8 \square \quad 8-14 \square \quad 15-21 \square \quad$ Mer enn 21 dager $\square$

Hvis du for tiden ikke har regelmessig menstruasjon,

ber vi deg fylle ut nedenfor (Sett bare eft kryss)

Menstruasjonen sluttet av seg selv for minst

6 mnd. siden (overgangsalder).

Menstruasjonen sluttet etter underlivs

operasjon, strálebehandling eller cellegift

Usikker på om menstruasjonen har sluttet

(mulig overgangsalder)

Gravid i mindre enn 6 måneder

Gravid i 6 máneder eller mer

Har nylig fodt eller ammer, og har ikke fât

menstruasjonen tilbake

Helt uregelmessige menstruasjoner

med svært korte eller svært lange pauser

Ingen elter uregelmessig menstruasjon

på grunn av hormonbehandling.

Har aldri hatt menstruasjoner

Hvis du ikke lenger har menstruasjon, hvor

gammel var du da den sluttet?

Alder i ár

Hvor mange barn (levende bam) har du fodt? Antall barn

Hvor lenge har du ammet dine barn til sammen?

(f.eks. 3 barn: $1+6+10=17$ máneder) ............Antall mnd.

Bruker du nă, eller har du tidligere brukt Ná Før, men

ikken

P-pille (ogsă minipille) eller p-sprøyte........

Vanlig spiral

Hormonspiral (pris ca. kr. 1000)

Østrogen/progesteron

(tabletter, plaster, sproyte)

Østrogen (krem eller stikkpiller)

Til deg som bruker p-pille, hormonspiral (ikke vanlig spiral) eller hormoner I overgangsalderen $\mathrm{NA}$ :

Hvilke(t) merke(r) bruker du?

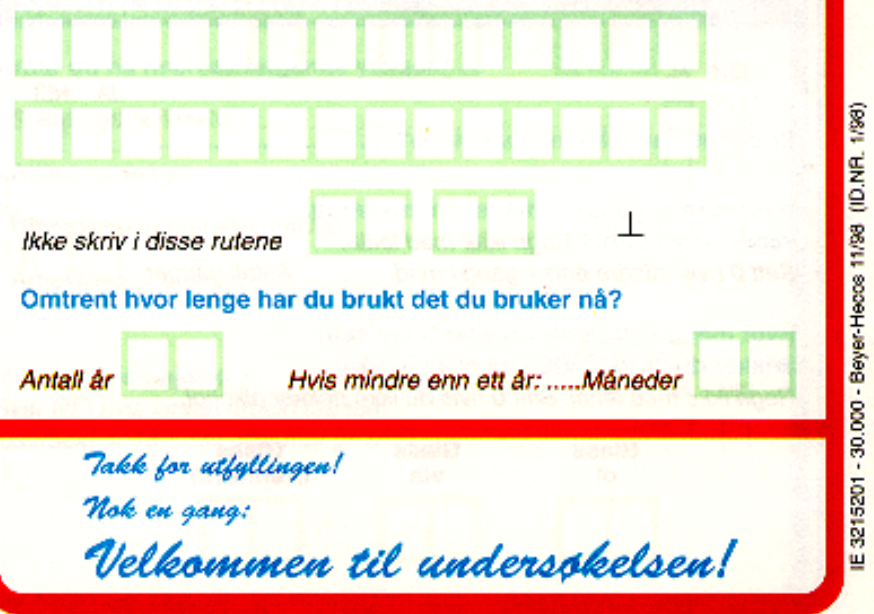



THE COUNTY STUDIES - QUESTIONNAIRE 



\begin{tabular}{|c|c|c|c|}
\hline A & JA $N E I$ & D & \\
\hline Har De, eller har De hatt: & & Royker De daglig for tiden ? . . . . . . s s2 & \\
\hline Hjerteinfarkt? .............. ss & & $\begin{array}{l}\text { Hvis svaret var "JA" på forrige sporsmål, } \\
\text { besvar da: }\end{array}$ & \\
\hline Angina pectoris (hjertekrampe)? . . . . . & & Royker De sigaretter daglig? . . . . . . & \\
\hline Annen hjertesykdom? . . . . . . . . ss & & (handrulle de eller fabrikkframstilte) & \\
\hline Åreforkalkning i bena? . . . . . . . . so & & Hvis De ikke royker sigaretter nå, besvar da. & \\
\hline Hjerneslag? . . . . . . . . . . . . st & & Har De roykt sigaretter daglig tidligere?. In & \\
\hline Sukkersyke? . . . . . . . . . . . so & & $\begin{array}{l}\text { Hyis De svarte JA", hvor lenge er det } \\
\text { siden De sluttet?" }\end{array}$ & \\
\hline Er De under behandling for: & & 1 Mindre enn 3 måneder? . . . . . ss & \\
\hline Hoyt blodtrykk? . . . . . . . . . ss & & 23 måneder - 1 år ? ........... & \\
\hline Bruker De: & & $1-5$ år? $\ldots \ldots \ldots \ldots \ldots$ & \\
\hline Nitroglycerin? . . . . . . . . . . . 40 & & 4 Mer enn 5 air? . . . . . . . . . & \\
\hline $\begin{array}{c}\text { B } \\
\text { Får De smerter eller ubehag i brystet når De: }\end{array}$ & JA NEI & $\begin{array}{l}\text { Besvares av dem som royker na eller har } \\
\text { roykt tidligere: }\end{array}$ & \\
\hline Går i bakker, trapper eller fort pa flat mark? " & & $\begin{array}{l}\text { Hvor mange or tilsammen har De }{ }^{\text {so-s7 }} \\
\text { roykt daglig? }\end{array}$ & \\
\hline $\begin{array}{l}\text { Går i vanlig takt på flat mark ? ....... } 42 \\
\text { Hvis De får smerter eller ubehag i brystet } \\
\text { ved gange, pleier De da } a \text { : }\end{array}$ & & $\begin{array}{l}\text { Hvor mange sigaretter royker eller } \\
\text { roykte De daglig? Oppoi arricallpr.dag } 10.4 \\
\text { (händrullede + fabrikkframstilte) }\end{array}$ & \\
\hline 1 Stanse? . . . . . . . . . & & Royker De noe annet enn sigaretter daglig? & \\
\hline 2 Saktne farten? ........... & & Sigarer eller serutter/cigarillos? . . on & \\
\hline 3 Fortsette i samme takt? .... & & Pipe? ................ & \\
\hline $\begin{array}{l}\text { Hvis De stanser eller saktner farten, } \\
\text { forsvinner smertene ds: }\end{array}$ & & $\begin{array}{l}\text { Hvis De royker pipe, hvor mange pakker } \\
\text { tobakk (50 gram) bruker De i pipa pr. uke? }\end{array}$ & \\
\hline 1 Etter mindre enn 10 minutter ?... . 4 & & Oppgi gjennomsnittlig antall pakker pr.uke. $e^{k \cdot u b}$ & \\
\hline 2. Etter mer enn 10 minutter? ... & & $\mathbf{E}$ & \\
\hline Får De smerter i tykkleggen når De & & Har De vanligvis skiftarbeid eller nattarbeid? 4 & \\
\hline Gair? . . . . . . . . . . . . ss & & Kan De vanligvis komme hiem fra arbeidet. & \\
\hline Eriro? $\ldots \ldots \ldots \ldots \ldots \ldots$ & & Hver dag? . . . . . . . . . . . . & \\
\hline Hvis De får leggsmerter, besvar da : & & Hver helg? . . . . . . . . . . . . . & \\
\hline $\begin{array}{l}\text { Forverres smertene ved raskere } \\
\text { tempo eller } i \text { bakker? } \ldots \text { at . . . . . . . }\end{array}$ & & $\begin{array}{l}\text { Har De i perioder lengre arbeidsdager } \\
\text { enn vanlig?.................. to }\end{array}$ & \\
\hline Gir smertene seg når De stopper? . . 48 & & $\begin{array}{l}\text { (f.eks. under sesongfiske, onnearbeid) } \\
\text { Har De i lopet av siste aret hatt. }\end{array}$ & \\
\hline Har De vanligvis: & & Settkryss $i$ den ruten hvor. JA" passer best & \\
\hline Hoste om morgenen? . . . . . . . 4 & & 1 Overveiende stillesittende arbeid? .." & \\
\hline Oppspytt fra brystet om morgenen? ... so & & ebordsarb., urmakerarb., montering) & \\
\hline C & $J A$ & $\begin{array}{l}2 \text { Arbeid som krever at De går mye? } \\
\text { (f.eks. okspeditorarb., latt industriarb., undervisn.) }\end{array}$ & \\
\hline $\begin{array}{l}\text { Deres frititeten varierer meget f.eks. } \\
\text { Hvis aktiviteter sommer og vinter sata et } \\
\text { mellom some }\end{array}$ & & $\begin{array}{l}3 \text { Arbeid hvor De gå og lofter mye?. . } \\
\text { (f.eks.postbud, trmgre industriarb, broningsarb) }\end{array}$ & \\
\hline & & 4 Tungt kroppsarbeid? . . . . . . . . . & \\
\hline Spersmålet gielder bare det siste o̊ret. & & $\begin{array}{l}\text { (f.eks. skogsarbeid, tungt jordbraksarb tungt } \\
\text { Drgningsorto ) }\end{array}$ & \\
\hline Sett kryss i den ruten hvor .JA" passer best. & & $\begin{array}{l}\text { HarDe i lopet av de siste } 12 \text { mnd mattet } \\
\text { flytte fra hiemstedet pă grunn av }\end{array}$ & \\
\hline $\begin{array}{l}1 \text { Leser, ser pa fiernsyn eller annen } \\
\text { stillesittende beskieftigelse? }{ }^{\prime} \ldots . . .\end{array}$ & & & \\
\hline $\begin{array}{l}2 \text { Spaserer sykler eller beveger Dem pa } \\
\text { annen mate minst } 4 \text { timer i iuken? }\end{array}$ & & eid Deres hove & \\
\hline $\begin{array}{l}\text { (Heri medregnes ogsa gang eller sylling) } \\
\text { til arbeidsstedet, sendagsturer m.m. }\end{array}$ & & 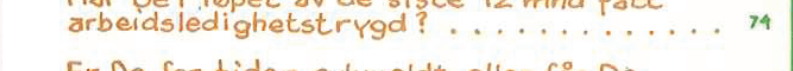 & \\
\hline $\begin{array}{l}3 \text { Driver mosionsidrett, tyngre hage- } \\
\text { arbeid e.L? }\end{array}$ & & $\begin{array}{l}\text { Er De for tiden sykmeldt, eller fä De } \\
\text { attforingspenger? } \ldots . . . \ldots \ldots\end{array}$ & \\
\hline $\begin{array}{l}\text { esomheten skal vare minst) } \\
\text { en. }\end{array}$ & & Har De full eller delvis uforepension?. . 16 & \\
\hline $\begin{array}{l}4 \text { Trener hardt eller driver konkurranse- } \\
\text { idrett, regelmessig og flere ganger } \\
\text { i uken?..................... }\end{array}$ & & $\begin{array}{l}\mathbf{F} \\
\text { Haren eller flere av foreldre eller sosken } \\
\text { hatt hierteinfarkt (sar po hiertet) } \\
\text { eller angina pectoris (hjertekrampe)? " }\end{array}$ & \\
\hline $\begin{array}{l}\text { G } \\
\text { Har noen i Deres husstand (utenom } \\
\text { Dem selv) vart innkalt til narmere under- } \\
\text { sokelse hos distriktslegen etter forrige } \\
\text { hierte-kar undersokelse? }\end{array}$ & IA NEI & $\begin{array}{l}\text { Er to eller flere av Deres besteforeldre } \\
\text { av finsk aett? .................. } \\
\text { Er to eller flere ov Deres besteforeldre } \\
\text { av samisk att? }{ }^{n}\end{array}$ & \\
\hline
\end{tabular}


MELDING OM SKJERMBILDEFOTOGRAFERING OG HJERTE-KARUNDERSØKELSE

(Gjelder bare den person brevet er adressert til)

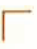

(1)

L

Født dato Personnr.

Møtested
Kommune

Forste

bokstav

etternavn Dag og dato
Skjermbildefotograferingen kommer nå til Deres distrikt.

Tid og sted for Deres frammøte vil De finne nedenfor.

Også denne gangen vil en del av befolkningen få tilbud om hjerte-karundersøkelse. De tilhører denne gruppe. En orientering om undersøkelsen er gitt i vedlagte brosjyre.

$\neg$ Vennligst fyll ut spørreskjemaet på baksiden og ta det med til undersøkelsen. Ta også med tuberkulinkort eller helsebok, om De har.

Fravær bes eventuelt meldt på vedlagte seddel.

Med hilsen

HELSERÅDET FYLKESLEGEN

STATENS SKJERMBILDEFOTOGRAFERING

Kretsnr.

Klokkeslett 
CONOR - QUESTIONNAIRE 



\begin{tabular}{|c|c|c|}
\hline $\begin{array}{l}\text { VARIABEL/ } \\
\text { VARIABLE }\end{array}$ & SPØRRESKJEMA NORSK (NORWEGIAN) & QUESTIONNAIRE IN ENGLISH \\
\hline & EGEN HELSE & YOUR OWN HEALTH \\
\hline a1 & $\begin{array}{l}\text { 1. Hvordan er helsen din nå? Sett bare ett kryss } \\
\text { Dårlig } \\
\text { Ikke helt god } \\
\text { God } \\
\text { Svært god }\end{array}$ & $\begin{array}{l}\text { 1. What is your current health status? Tick one only } \\
\text { Poor } \\
\text { Not so good } \\
\text { Good } \\
\text { Very good }\end{array}$ \\
\hline a2_1 to a2_10 & $\begin{array}{l}\text { 2. Har du eller har du hatt? } \\
\text { Hjerteinfarkt } \\
\text { Angina pectoris } \\
\text { (hjertekrampe) } \\
\text { Hjerneslag/ } \\
\text { Hjerneblødning } \\
\text { Astma } \\
\text { Diabetes (sukkersyke) }\end{array}$ & $\begin{array}{l}\text { 2. Do you have, or have you had? } \\
\text { Yes No Age first time } \\
\text { Heart attack } \\
\text { Angina pectoris } \\
\text { (heart cramp) } \\
\text { Cerebral stroke/ } \\
\text { Brain haemorrhage } \\
\text { Asthma } \\
\text { Diabetes }\end{array}$ \\
\hline a4 & $\begin{array}{l}\text { 3. Har du i løpet av siste året vært plaget med smerter } \\
\text { og/eller } \\
\text { stivhet i muskler og ledd som har vart i minst } 3 \text { måneder } \\
\text { sammenhengende? } \\
\text { Ja } \\
\text { Nei }\end{array}$ & $\begin{array}{l}\text { 3. Have you during the last year suffered from pain and/or } \\
\text { stiffness in muscles and joints that have lasted for at least } 3 \text { month } \\
\text { Yes } \\
\text { No }\end{array}$ \\
\hline a5_1 to a5_7 & \begin{tabular}{l} 
4. Har du de to siste ukene følt deg: \\
\multicolumn{1}{l}{ Nei Litt En god del Svært } \\
mye \\
Nervøs og urolig \\
Plaget av angst \\
Trygg og rolig \\
Irritabel \\
Glad/optimistisk \\
Nedfor/deprimert \\
Ensom
\end{tabular} & $\begin{array}{l}\text { 4. Have you in the last two weeks felt : } \\
\qquad \text { No A little A lot Very much } \\
\text { Nervous or worried } \\
\text { Anxious } \\
\text { Confident and calm } \\
\text { Irritable } \\
\text { Happy/Optimistic } \\
\text { Down/Depressed } \\
\text { Lonely }\end{array}$ \\
\hline & FYSISK AKTIVITET & PHYSICAL ACTIVIYY \\
\hline a6_1 to a6_2 & 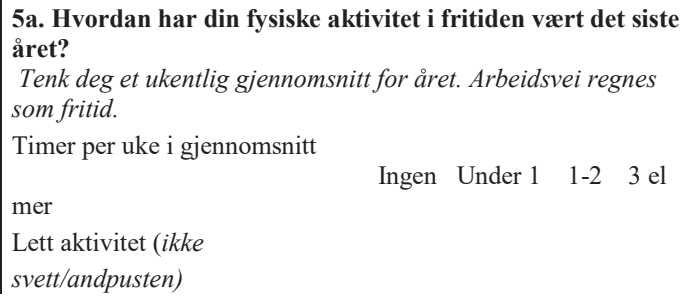 & 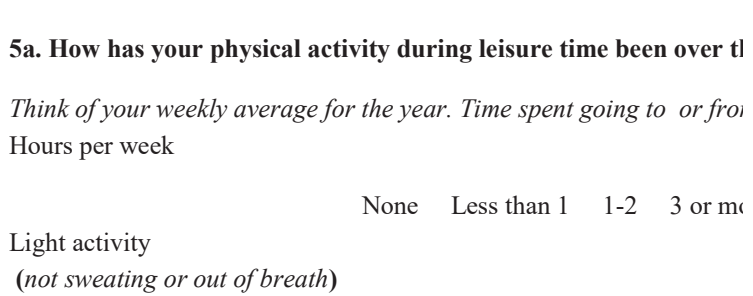 \\
\hline
\end{tabular}




\begin{tabular}{|c|c|c|}
\hline & $\begin{array}{l}\text { Hard fysisk aktivitet } \\
\text { (svett/andpusten) }\end{array}$ & $\begin{array}{l}\text { Hard physical activity } \\
\text { (sweating/out of breath) }\end{array}$ \\
\hline a6_3 & $\begin{array}{l}\mathbf{5} \text { b. Angi bevegelse og kroppslig anstrengelse i din fritid. } \\
\text { Hvis aktiviteten } \\
\text { varierer meget f.eks mellom sommer og vinter, så ta et } \\
\text { gjennomsnitt. } \\
\text { Spørsmålet gjelder bare det siste året. } \\
\text { (Sett ett kryss } \text { i den ruta som passer best) } \\
\text { Lese, ser på fjernsyn eller annen stillesittende beskjeftigelse? } \\
\text { Spaserer, sykler eller beveger deg på annen måte minst } 4 \text { timer i } \\
\underline{\text { uka? }} \\
\text { (Her skal du regne med gang eller sykling til arbeidsstedet, } \\
\text { søndagsturer m.m) } \\
\text { Driver mosjonsidrett, tyngre hagearbeid e.l? } \\
\text { (Merk at aktiviteten skal vare minst } 4 \text { timer } i \text { uka) } \\
\text { Trener hardt eller driver konkurranseidrett regelmessig og flere } \\
\text { ganger i uka }\end{array}$ & $\begin{array}{l}5 \text { b. Please note physical activity during the past year in your spai } \\
\text { If activity varies between summer and wintertime, } \\
\text { note a mean value. } \\
\text { (Tick one only) } \\
\text { Reading, watching TV or any other sedentary activity? } \\
\text { Walking, cycling, or other activity, other for at least } 4 \text { hours a week? } \\
\text { (Count also walking back and forth from work) } \\
\text { Light sports, heavy gardening? } \\
\text { (At least } 4 \text { thours perweek) } \\
\text { Hard exercise, competitive sports? Regularly and several times a wee }\end{array}$ \\
\hline & RØYKING & SMOKING \\
\hline a7_2 & $\begin{array}{l}\text { 6. Hvor lenge er du vanligvis daglig til stede i røykfylt rom? } \\
\text { Sett } 0 \text { hvis du ikke oppholder deg i røykfylt rom. } \\
\text { Antall timer........... }\end{array}$ & $\begin{array}{l}\text { 6. How many hours a day do you normally spend in smoke-filled } 1 \\
\text { Write } 0 \text { if you don 't spend time in smoke-filled rooms } \\
\text { Number of hours........... }\end{array}$ \\
\hline a7_3 & $\begin{array}{l}\text { 7. Røkte noen av de voksne hjemme da du vokste opp? } \\
\text { Ja } \\
\text { Nei }\end{array}$ & $\begin{array}{l}\text { 7. Did any of the adults smoke at home when you grew up? } \\
\text { Yes } \\
\text { No }\end{array}$ \\
\hline a7_4 & $\begin{array}{l}\text { 8. Bor du/har du bodd sammen med noen daglig-røykere } \\
\text { etter fylte } 20 \text { år? } \\
\text { Ja } \\
\text { Nei }\end{array}$ & $\begin{array}{l}\text { 8. Do you now, or have you ever lived together with a daily smokeı } \\
\text { Yes } \\
\text { No }\end{array}$ \\
\hline a8_0 to a8_3 & $\begin{array}{l}\text { 9. Røyker du selv? } \\
\text { Sigaretter daglig } \\
\text { Sigarer/sigarillos daglig } \\
\text { Pipe daglig }\end{array}$ & $\begin{array}{l}\text { 9. Do you smoke ? } \\
\text { Cigarettes daily } \\
\text { Cigars/cigarillos daily } \\
\text { Pipe daily }\end{array}$ \\
\hline a9 & $\begin{array}{l}\text { 10. Hvis du har røykt daglig tidligere, hvor lenge er det } \\
\text { siden du sluttet? } \\
\text {.......år }\end{array}$ & $\begin{array}{l}\text { 10. If you previously smoked daily, how long is it since you quit? } \\
\ldots \ldots \ldots \text { number of years }\end{array}$ \\
\hline a10 & $\begin{array}{l}\text { 11. Hvis du røker daglig nå eller har røykt tidligere: } \\
\text { Hvor mange sigaretter røyker eller røykte du vanligvis } \\
\text { daglig? } \\
\text { Antall sigaretter.............. }\end{array}$ & $\begin{array}{l}\text { 11. If you smoke daily now or previously: } \\
\text { How many cigarettes do you,or did you usually smoke per day? } \\
\text { Number of cigarettes.............. }\end{array}$ \\
\hline a11 & $\begin{array}{l}\text { 12. Hvor gammel var du da du begynte å røyke? } \\
\text {.........år }\end{array}$ & $\begin{array}{l}\text { 12. How old were you when you began smoking? } \\
\text {.........year }\end{array}$ \\
\hline a12_1 & $\begin{array}{l}\text { 13. Hvor mange år til sammen har du røykt daglig? } \\
\text { ….......år }\end{array}$ & $\begin{array}{l}\text { 13. How many years in all have you smoked daily? } \\
\ldots \ldots \ldots \ldots \text {......ears }\end{array}$ \\
\hline
\end{tabular}




\begin{tabular}{|c|c|c|}
\hline & KAFFE, TE OG ALKOHOL & COFFEE, TEA AND ALCOHOL \\
\hline $\begin{array}{l}\text { a13_1 to a13_2 } \\
\text { a13_4 }\end{array}$ & $\begin{array}{l}\text { 14.a Hvor mange kopper kaffe drikker du daglig? } \\
\text { Sett } 0 \text { hvis du ikke drikker kaffe daglig } \\
\text { Kokekaffe, antall kopper............. } \\
\text { Annen kaffe, antall kopper........... }\end{array}$ & $\begin{array}{l}\text { 14.a How many cups of coffee do you usually drink daily? } \\
\text { Write } 0 \text { if you do not drink coffee daily } \\
\text { Boiled coffee (coarsely ground), number...... } \\
\text { Coffee other, number............ }\end{array}$ \\
\hline a13_5 to a13_8 & $\begin{array}{l}\text { 14.b Hva slags kaffe drikke du vanligvis? } \\
\text { Sett kryss } \\
\text { Filter-/pulverkaffe } \\
\text { Kokekaffe/trykkanne } \\
\text { Annen kaffe (espresso og lignende) } \\
\text { Drikker ikke kaffe } \\
\end{array}$ & $\begin{array}{l}\text { 14.b What type of coffee do you usually drink? } \\
\text { Please tick } \\
\text { Filter/instant coffee } \\
\text { Boiled coffee (coarsely ground) } \\
\text { Other (espresso etc) } \\
\text { Do not drink coffee } \\
\end{array}$ \\
\hline a13_9 to a13_10 & $\begin{array}{l}\text { 14c. Hvor mange kopper kaffe/te drikker du daglig? } \\
\text { Sett } 0 \text { hvis du ikke drikker kaffe/te daglig } \\
\text { Antall kopper kaffe............. } \\
\text { Antall kopper te............ }\end{array}$ & $\begin{array}{l}\text { 14c. How many cups of coffee/tea do you usually drink daily? } \\
\text { Write } 0 \text { if you do not drink coffee/tea daily } \\
\text { Number of cups with coffee............ } \\
\text { Number of cups with tea............ }\end{array}$ \\
\hline $\begin{array}{l}\text { a14_1 and a14_1_2 } \\
\text { (a14_1 made of } 14 \_1 \_1 \\
\left.\text { and } 14 \_1 \_2\right)\end{array}$ & $\begin{array}{l}15 \text { a. Hvor mange ganger i måneden drikker du vanligvis } \\
\text { alkohol? } \\
\text { Regn ikke med lettøl. Sett } 0 \text { hvis mindre enn } 1 \text { gang i måneden. } \\
\text { Antall ganger............ }\end{array}$ & $\begin{array}{l}15 \text { a. How many times a month do you usually drink alcohol? } \\
\text { Do not count low-alcohol beer. Put } 0 \text { if less than once a month. } \\
\text { Number of times............ }\end{array}$ \\
\hline $\begin{array}{l}\text { a14_1 and a14_1_1 } \\
\text { (a14_1 made of } 14 \_1 \_1 \\
\left.\text { and } 14 \_1 \_2\right)\end{array}$ & $\begin{array}{l}\mathbf{1 5} \text { b. Omtrent hvor ofte har du i løpet av det siste året } \\
\text { drukket alkohol? } \\
\text { (Lettøl og alkoholfritt øl regnes ikke med) } \\
\text { 4-7 ganger i uka } \\
\text { 2-3 ganger i uka } \\
\text { Ca 1.gang i uka } \\
\text { 2-3 ganger pr måned } \\
\text { Omtrent1 gang i mnd. } \\
\text { Noen få ganger siste år } \\
\text { Har ikke drukket alkohol siste år } \\
\text { Har aldri drukket alkohol }\end{array}$ & $\begin{array}{l}\text { 15 b. Approximately how often during the past } 12 \text { months have yo } \\
\text { (Do not count low-alcohol beer) } \\
4-7 \text { times a week } \\
\text { 2-3 times a week } \\
\text { App. } 1 \text { time a week } \\
\text { 2-3 times a month } \\
\text { Appr. } 1 \text { time a month } \\
\text { A few times last year } \\
\text { Have not drunk alcohol the last year } \\
\text { Have never drunk alcohol }\end{array}$ \\
\hline a14_4_1, a14_5_1 & $\begin{array}{l}16 \text { a. Hvor mange glass øl, vin eller brennevin } \\
\text { drikker du vanligvis i løpet av to uker? } \\
\text { Regn ikke med lettøl. Sett } 0 \text { hvis du ikke drikker alkohol. } \\
\varnothing 1 . . . . \text { glass Vin.....glass Brennevin.....glass }\end{array}$ & $\begin{array}{l}16 \text { a. How many glasses of beer, wine or spirits } \\
\text { do you usually drink during a two-weeks period? } \\
\text { Do not count low-alcohol beer. Put } 0 \text { if you do not drink alcohol. } \\
\text { Beer.....glasses Wine.....glasses Spirits.....glasses }\end{array}$ \\
\hline a14_2 & $\begin{array}{l}\text { Til dem som har drukket siste år } \\
\mathbf{1 6} \text { b. Når du har drukket alkohol, hvor mange glass/og eller } \\
\text { drinker } \\
\text { har du vanligvis drukket? } \\
\text { Antall............ }\end{array}$ & $\begin{array}{l}\text { For those who have consumed alcohol during the past year } \\
\mathbf{1 6} \mathbf{b} \text {. When you drank alcohol, how many glasses } \\
\text { did you usually drink ? } \\
\text { Number of glasses............ }\end{array}$ \\
\hline a14_3 & $\begin{array}{l}16 \text { c. Omtrent hvor mange ganger i løpet av det siste året } \\
\text { har du drukket så mye } \\
\text { som minst } 5 \text { glass og/eller drinker i løpet av et døgn? } \\
\text { Antall ganger........... }\end{array}$ & $\begin{array}{l}16 \text { c. Approximately how often during the past } 12 \text { months have yo } \\
\text { corresponding to at least } 5 \text { glasses of spirits in } 24 \text { hours? } \\
\text { Number of times......... }\end{array}$ \\
\hline $\begin{array}{l}\text { a14_4, a14_5, } \\
\text { a14 6, a14 } 6 \text { 1 }\end{array}$ & $\begin{array}{l}16 \text { d. Når du drikker alkohol, drikker du da vanligvis: (Sett } \\
\text { ett eller flere kryss). } \\
\varnothing 1 \quad \text { Vin }\end{array}$ & $\begin{array}{l}\mathbf{1 6} \mathbf{d} \text {. When you drink alcohol, do you usually drink: (Tick one or } n \\
\text { Beer } \quad \text { Wine } \quad \text { Spirits (hard liquor) }\end{array}$ \\
\hline
\end{tabular}




\begin{tabular}{|c|c|c|}
\hline a14_7 & $\begin{array}{l}\text { 17. Er du total avholdsmann/-kvinne? } \\
\text { Ja } \\
\text { Nei }\end{array}$ & $\begin{array}{l}\text { 17. Are you a total abstainer from alcohol? } \\
\text { Yes } \\
\text { No }\end{array}$ \\
\hline & SKOLEGANG & EDUCATION \\
\hline $\begin{array}{l}\text { a15, a15_2 } \\
\text { (made of a15_1 and } \\
\text { a15_2) }\end{array}$ & $\begin{array}{l}18 \text { a. Hvilken utdanning er den høyeste du har fullført? } \\
\text { Mindre enn } 7 \text { år grunnskole } \\
\text { Grunnskole 7-10 år, framhaldsskole, folkehøyskole } \\
\text { Realskole, middelskole, yrkesskole, } 1 \text {-2 årig videregående skole } \\
\text { Artium, økonomisk gymnas, allmennfaglig retning } \mathrm{i} \\
\text { videregående skole } \\
\text { Høgskole/universitet, mindre enn } 4 \text { år } \\
\text { Høgskole/universitet, } 4 \text { år eller mer }\end{array}$ & $\begin{array}{l}18 \text { a. What is the highest level of education you have completed? } \\
\text { Less than } 7 \text { year of primary school } \\
7-10 \text { years primary/secondary school } \\
\text { Technical school, middle school, vocational school, 1-2 years senior h } \\
\text { High school diploma (3-4 years) } \\
\text { College/university, less than } 4 \text { years } \\
\text { College/university, } 4 \text { or more years }\end{array}$ \\
\hline \multirow[t]{2}{*}{$\begin{array}{l}\text { 15, a15_1 } \\
\text { (made of a15_1 and } \\
\text { a15_2) }\end{array}$} & $\begin{array}{l}18 \text { b. Hvor mange års skolegang har du gjennomført? } \\
\text { (Ta med alle år du har gått på skole eller studert) } \\
\text { Antall år........... }\end{array}$ & $\begin{array}{l}18 \text { b. How many years education have you completed all together? } \\
\text { (Count every year you went to school) } \\
\text { Number of years............ }\end{array}$ \\
\hline & SYKDOM I FAMILIEN & ILLNESS IN THE FAMILY \\
\hline a16 & $\begin{array}{l}\text { 19. Har en eller flere av foreldre eller søsken hatt } \\
\text { hjerteinfarkt (sår på hjertet) } \\
\text { eller angina pectoris (hjertekrampe)? } \\
\mathrm{Ja} \\
\mathrm{Nei} \\
\text { Vet ikke }\end{array}$ & $\begin{array}{l}\text { 19. Have one or more of your parents or siblings had a heart attac } \\
\text { or angina pectoris? } \\
\text { Yes } \\
\text { No } \\
\text { Don't know }\end{array}$ \\
\hline \multirow[t]{2}{*}{ b15_1 to b15_30 } & $\begin{array}{l}\text { 20. Kryss for de slektninger som har eller har hatt noen av } \\
\text { sykdommene: } \\
\text { Barn } \\
\text { Hjerneslag eller } \\
\text { hjerneblødning } \\
\text { Hjerteinfarkt før } 60 \\
\text { års alder } \\
\text { Astma } \\
\text { Kreftsykdom } \\
\text { Sukkersyke (diabetes) } \\
\text { Alder da de fikk sukkersyke }\end{array}$ & $\begin{array}{l}\text { 20. Tick for those relatives who have or have had: } \\
\qquad \text { Mother Father Brother Sister Child } \\
\text { Cerebral stroke or } \\
\text { brain haemorrhage } \\
\text { Myocardial infarction } \\
\text { before age } 60 \\
\text { Asthma } \\
\text { Cancer } \\
\text { Diabetes } \\
\text { Age when diabetes was first diagnosed }\end{array}$ \\
\hline & LOKALMILJØ OG BOLIG & RESIDENLY \\
\hline b1 & $\begin{array}{l}\text { 21. I hvilken kommune bodde du da du fylte } 1 \text { år? } \\
\text { Hvis du ikke bodde } i \text { Norge, oppgi hvilket land } i \text { stedet for } \\
\text { fylke. } \\
\text {........................ }\end{array}$ & $\begin{array}{l}\text { 21. In which muncipality did you live at the age of } 1 \text { year? } \\
\text { If you did not live in Norway, give country of residence instead of mun } \\
\text {.......................... }\end{array}$ \\
\hline b2 & $\begin{array}{l}\text { 22. Hvilken type bolig bor du i? } \\
\text { Enebolig/ villa } \\
\text { Gårdsbruk } \\
\text { Blokk/terrasseleilighet } \\
\text { Rekkehus/2-4mannsbolig } \\
\text { Annen bolig/institusjon/omsorgsbolig }\end{array}$ & $\begin{array}{l}\text { 22. What type of dwelling do you live in? } \\
\text { Villa/detached house } \\
\text { Farm } \\
\text { Flat/apartment } \\
\text { Terraced/semi-detached house } \\
\text { Other/institution/care home }\end{array}$ \\
\hline b3 & $\begin{array}{l}\text { 23. Hvor stor er din boenhet? } \\
\text {........m } 2\end{array}$ & $\begin{array}{l}\text { 23. How large is your home? } \\
\ldots \ldots \ldots \mathrm{m} 2\end{array}$ \\
\hline
\end{tabular}




\begin{tabular}{|c|c|c|}
\hline \multirow[t]{2}{*}{ b29 } & 24. Er det heldekkende tepper i stua? & 24. Do you have wall-to-wall carpets in the living-room? \\
\hline & Nei & Yes \\
\hline b30 & $\begin{array}{l}\text { 25. Er det katt i boligen? } \\
\text { Ja } \quad \text { Nei } \\
\end{array}$ & $\begin{array}{l}\text { 25. Is there a cat in your home? } \\
\text { Yes No }\end{array}$ \\
\hline & FAMILIE OG VENNER & FAMILY AND FRIENDS \\
\hline Sjekke & $\begin{array}{l}\text { 26a. Hvem bor du sammen med? Sett ett kryss for hvert } \\
\text { spørsmål og angi antall. } \\
\text { Antall } \\
\text { Ektefelle/samboer } \\
\text { Andre personer over } 18 \text { år } \\
\text { Personer under } 18 \text { år } \\
\end{array}$ & $\begin{array}{l}26 \text { a. With whom do you live? Tick one for each question and write } \\
\qquad \text { Yes No Numb } \\
\text { Spouse/Partner } \\
\text { Other persons older than } 18 \text { years } \\
\text { Persons younger than } 18 \text { years } \\
\end{array}$ \\
\hline b4_1 to b4_6 & $\begin{array}{l}26 \text { b. Bor du sammen med noen? } \\
\text { Ja } \\
\text { Nei } \\
\text { Hvis JA: } \\
\text { Antall } \\
\text { Ektefelle/samboer } \\
\text { Andre personer, } 18 \text { år og eldre } \\
\text { Personer under } 18 \text { år } \\
\end{array}$ & $\begin{array}{l}26 \text { b. Do you live with anyone? } \\
\text { Yes } \\
\text { No } \\
\text { If YES: } \\
\text { Spouse/Partner } \\
\text { Other persons older than } 18 \text { years } \\
\text { Persons younger than } 18 \text { years }\end{array}$ \\
\hline b4_7 and b4_8 & $\begin{array}{l}26 \text { c (kun på eldreskjema) } \\
\text { Bor du ? Sett kryss } \\
\text { Hjemme } \\
\text { Institusjon/bofellesskap } \\
\text { Bor du sammen med? Ja } \\
\text { Ektefelle/samboer? } \\
\text { Andre personer? } \\
\end{array}$ & $\begin{array}{l}26 \text { c (only at the questionary for the elderly) } \\
\text { Where do you live? Please tick } \\
\text { Home } \\
\text { Institution } \\
\text { Do you live with? Yes No } \\
\text { Spouse/Partner? } \\
\text { Other persones? }\end{array}$ \\
\hline b31 & $\begin{array}{l}\text { 27. Hvor mange av barna har plass i barnehage? } \\
\ldots \ldots \ldots \ldots\end{array}$ & $\begin{array}{l}\text { 27. How many of the children attend day care/kindergarten/nurse } \\
\ldots \ldots \ldots \text {. }\end{array}$ \\
\hline b5 & $\begin{array}{l}\text { 28. Hvor mange gode venner har du? Regn med de du kan } \\
\text { snakke fortrolig } \\
\text { med og som kan gi deg hjelp når du trenger det? } \\
\text { (Tell ikke med de du bor sammen med, men ta med andre } \\
\text { slektninger) } \\
\text {........................... }\end{array}$ & $\begin{array}{l}\text { 28. How many good friends do you have with whom you can talk c } \\
\text { and who can provide help if you need it? } \\
\text { (Do not count people you live with, but do include other relatives) } \\
\text {........................ }\end{array}$ \\
\hline b6 & $\begin{array}{l}\text { 29. Føler du at du har nok gode venner? } \\
\text { Ja } \\
\text { Nei }\end{array}$ & $\begin{array}{l}\text { 29. Do you feel that you have enough good friends? } \\
\text { Yes } \\
\text { No } \\
\end{array}$ \\
\hline b7 & $\begin{array}{l}\text { 30. Hvor ofte tar du vanligvis del i foreningsvirksomhet som } \\
\text { for eksempel } \\
\text { syklubb, idrettslag, politiske lag, religiøse eller andre } \\
\text { foreninger? } \\
\text { Aldri, eller noen få ganger i året } \\
\text { 1-2 ganger i måneden (før år 1996), 1-3 ganger i måneden (etter } \\
\text { år 1996) }\end{array}$ & $\begin{array}{l}\text { 30. How often do you usually take part in organised activities, e.g. } \\
\text { sewing circles, sports clubs, political meetings, religious or other o } \\
\text { Never, or just a few times a year } \\
\text { 1-2 times a month (before year 1996), 1-3 times a month (after year 1s }\end{array}$ \\
\hline
\end{tabular}




\begin{tabular}{|c|c|c|}
\hline & $\begin{array}{l}\text { Omtrent } 1 \text { gang i uken } \\
\text { Mer enn en gang i uken }\end{array}$ & $\begin{array}{l}\text { Approximately once a week } \\
\text { More than once a week }\end{array}$ \\
\hline & ARBEID & WORK \\
\hline b8_1 to b8_4 & $\begin{array}{l}\text { 31. Hva slags arbeidssituasjon har du nå? } \\
\text { Lønnet arbeid } \\
\text { Heltids husarbeid } \\
\text { Utdanning, militærtjeneste } \\
\text { Arbeidsledig, permittert }\end{array}$ & $\begin{array}{l}\text { 31. What is your current work situation? } \\
\text { Paid work } \\
\text { Full-time housework } \\
\text { Under education, military service } \\
\text { Unemployed, on leave without payment }\end{array}$ \\
\hline b9 and b9_1 & $\begin{array}{l}\text { 32a. Hvor mange timer lønnet arbeid har du i uka? } \\
\text {.............timer }\end{array}$ & $\begin{array}{l}32 \text { a. How many hours of paid work do you have per week? } \\
\ldots \ldots \ldots \ldots \ldots \ldots \text { number of hours }\end{array}$ \\
\hline b9 & $\begin{array}{l}32 \text { b. Er du i inntektsgivende arbeid? } \\
\mathrm{Ja} \text {, full tid } \\
\mathrm{Ja} \text {, deltid } \\
\mathrm{Nei}\end{array}$ & $\begin{array}{l}32 \text { b. What is your current work situation - paid work? } \\
\text { Yes, full-time } \\
\text { Yes, part time } \\
\text { No }\end{array}$ \\
\hline $\begin{array}{l}\text { b10_1, b10_2, b10_3 } \\
\text { b10_4, b10_5, b10_6 } \\
\text { b10_7 }\end{array}$ & $\begin{array}{l}\text { 33. Mottar du noen av følgende ytelser? } \\
\text { Sykepenger (er sykemeldt) } \\
\text { Alderstrygd, førtidspensjon (AFP) eller etterlattepensjon } \\
\text { Rehabiliterings-/attføringspenger } \\
\text { Uførepensjon (helt eller delvis) } \\
\text { Dagpenger under arbeidsledighet } \\
\text { Solsialhjelp/stønad } \\
\text { Overgangsstønad for enslige forsørgere }\end{array}$ & $\begin{array}{l}\text { 33. Do you receive any of the following? } \\
\text { Sickness benefit? } \\
\text { Old-age pension? } \\
\text { Rehabilitation benefit? } \\
\text { Disability pension? } \\
\text { Unemployment benefits? } \\
\text { Social welfare benefits? } \\
\text { Social benefit-single parent? }\end{array}$ \\
\hline b11 & $\begin{array}{l}\text { 34. Har du skiftarbeid, nattarbeid eller går vakter? } \\
\text { Ja } \\
\text { Nei }\end{array}$ & $\begin{array}{l}\text { 34. Do you work shifts or nights? } \\
\text { Yes } \\
\text { No }\end{array}$ \\
\hline b12 & $\begin{array}{l}\text { 35. Hvis du er i lønnet eller ulønnet arbeid, hvordan vil du } \\
\text { beskrive arbeidet ditt? } \\
\text { For det meste stillesittende arbeid? } \\
\text { (f.eks1 skrivebordsarbeid, montering) } \\
\text { Arbeid som krever at du går mye? } \\
\text { (f.eks ekspeditørarbeid, lett industriarbeid, undervisning) } \\
\text { Arbeid der du går og løfter mye? } \\
\text { (f.eks postbud, pleier, bygningsarbeider) } \\
\text { Tungt kroppsarbeid?(f.eks skogsarbeid, tungt jordbruksarbeid, } \\
\text { tungt bygningsarbeid) }\end{array}$ & $\begin{array}{l}\text { 35. If you have paid or unpaid work, which statement describes yo } \\
\text { Mostly sedentary work? } \\
\text { (e.g. office work, mounting) } \\
\text { Work that requires a lot of walking? } \\
\text { (e.g. shop assistant, light industrial work, teaching) } \\
\text { Work that requires a lot of walking and lifting? } \\
\text { (e.g. postman, nursing, construction) } \\
\text { Heavy manual labour? (e.g. forestry, heavy farmwork, heavy construcl }\end{array}$ \\
\hline b32 & $\begin{array}{l}\text { 36. Kan du selv bestemme hvordan arbeidet ditt skal legges } \\
\text { opp? (Sett bare ett kryss) } \\
\text { Nei, ikke i det hele tatt } \\
\text { I liten grad } \\
\text { Ja, stort sett } \\
\text { Ja, det bestemmer jeg selv }\end{array}$ & $\begin{array}{l}\text { 36. Do you_decide yourself how your work will be done? (Tick one } \\
\text { Not at all } \\
\text { Very little } \\
\text { Yes, sometimes } \\
\text { Yes, my own decision }\end{array}$ \\
\hline b33_1, b33_2, b33_3 & $\begin{array}{l}\text { 37a. Har du noen av følgende yrker? } \\
\text { (heltid eller deltid) Sett kryss for hvert spørsmål } \\
\text { Sjåfør } \\
\text { Bonde/gårdbruker }\end{array}$ & $\begin{array}{l}37 \text { a. Do you have any of the following occupations? } \\
\text { (full time or part time) Tick one for each question } \\
\qquad \text { Yes No } \\
\text { Driver } \\
\text { Farmer }\end{array}$ \\
\hline
\end{tabular}




\begin{tabular}{|c|c|c|}
\hline & Fisker & Fisherman \\
\hline \multirow[t]{2}{*}{ b33_4, b33_5 } & $\begin{array}{l}\text { 37b. Hvilket yrke/tittel har eller hadde du på dette } \\
\text { arbeidsstedet? } \\
\text { (spørsmålet henviser til et mellomliggende spørsmål (ikke } \\
\text { CONOR)om } \\
\text { den virksomhet man har arbeidet i lengst tid siste } 12 \text { mnd) } \\
\text { (For eksempel; sekretcer, loerer, industriarbeider, barnepleier, } \\
\text { møbelsnekker, } \\
\text { avdelingsleder, selger sjåfør e.l) } \\
\text { Yrke................................................. }\end{array}$ & 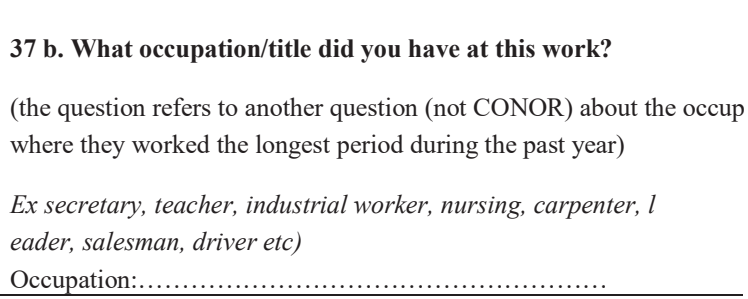 \\
\hline & SYKDOM OG SKADER & YOUR OWN ILLNESS and INJURIES \\
\hline $\begin{array}{l}\text { b13_1, b13_2, b13_3 } \\
\text { b13_4, b13_5, b13_6 } \\
\text { b13_7, b13_8 }\end{array}$ & $\begin{array}{l}\text { 38. Har du noen gang hatt: } \\
\text { Sett et kryss for hvert spørsmål. Oppgi også alder ved } \\
\text { hendelsen. } \\
\text { Hvis det har skjedd flere ganger, hvor gammel var du siste } \\
\text { gang. } \\
\text { Aldersiste gang } \\
\text { Lårhalsbrudd } \\
\text { Brudd ved håndledd/underarm } \\
\text { Nakkesleng (whiplash) } \\
\text { Skade som førte til syke- } \\
\text { husinnleggelse }\end{array}$ & $\begin{array}{l}\text { 38. Have you ever had: } \\
\text { Tick one for each question. State age at event. } \\
\text { If it has happened several times, write age at the last event. } \\
\qquad \text { Yes No Age at last time } \\
\text { Hip fracture } \\
\text { Wrist/forearm fracture } \\
\text { Whiplash } \\
\text { Injury requiring hospital } \\
\text { admission }\end{array}$ \\
\hline $\begin{array}{l}\text { b14_1, b14_2, b14_3 } \\
\text { b14_4, b14_5 }\end{array}$ & $\begin{array}{l}\text { 39. Har du eller har du hatt? } \\
\text { Kryss av ja eller nei for hvert spørsmål } \\
\text { Nei } \\
\text { Høysnue } \\
\text { Kronisk bronkitt/emfysem } \\
\text { Benskjørhet (osteoporose) } \\
\text { Fibromyalgi/fibrositt/kronisk)smertesykdom } \\
\text { Psykiske plager som du har søkt hjelp for } \\
\end{array}$ & $\begin{array}{l}\text { 39. Do you have or have you ever had? } \\
\text { Tick yes or no for each question } \\
\text { Hay fever } \\
\text { Chronic bronchitis/emphysema } \\
\text { Osteoporosis } \\
\text { Fibromyalgia/fibrositis/chronic pain syndrome } \\
\text { Psychological problems for which you have sought help }\end{array}$ \\
\hline b17 & $\begin{array}{l}\text { 40. Hoster du omtrent daglig i perioder av året? } \\
\mathrm{Ja}\end{array}$ & $\begin{array}{l}\text { 40. Do you cough almost daily for some periods of the year? } \\
\text { Yes No }\end{array}$ \\
\hline b18 & $\begin{array}{l}\text { 41. Hvis ja: } \\
\text { Er hosten vanligvis ledsaget av oppspytt? } \\
\text { Ja } \quad \text { Nei }\end{array}$ & $\begin{array}{l}\text { 41. If yes, } \\
\text { do you bring up phlegm? } \\
\text { Yes No }\end{array}$ \\
\hline b19 & $\begin{array}{l}\text { 42. Har du hatt slik hoste så lenge som i en } \mathbf{3} \text { måneders } \\
\text { periode } \mathrm{i} \\
\text { begge de to siste år? } \\
\mathrm{Ja} \quad \mathrm{Nei} \\
\end{array}$ & $\begin{array}{l}\text { 42. If you cough almost daily for some periods of the year, have yo } \\
\text { kind of cough for as long as } 3 \text { months in each of the last two years: } \\
\text { Yes No }\end{array}$ \\
\hline b20 & $\begin{array}{l}\text { 43. Hvor ofte er du plaget av søvnløshet? } \\
\text { Aldri, eller noen få ganger i året } \\
\text { 1-2 ganger i måneden (før år 2000), 1-3 ganger i måneden (etter } \\
\text { år 2000) } \\
\text { Omtrent } 1 \text { gang i uken } \\
\text { Mer enn } 1 \text { gang i uken }\end{array}$ & $\begin{array}{l}\text { 43. How often do you suffer from sleeplessness? } \\
\text { Never, or just a few times a year } \\
1-2 \text { times a month (before year 2000), 1-3 times a month (after year } 2( \\
\text { Approximately once a week } \\
\text { More than once a week }\end{array}$ \\
\hline b21 & $\begin{array}{l}\text { 44. Har du siste året vært plaget av søvnløshet } \\
\text { som har gått utover arbeidsevnen? } \\
\text { Nei }\end{array}$ & $\begin{array}{l}\text { 44. Have you in the last twelve months suffered from sleeplessness } \\
\text { to the extent that it has affected your ability to work? Yes }\end{array}$ \\
\hline
\end{tabular}




\begin{tabular}{|c|c|c|}
\hline & BRUK AV MEDISINER & USE OF MEDICATION \\
\hline b16_1, b16_2 & 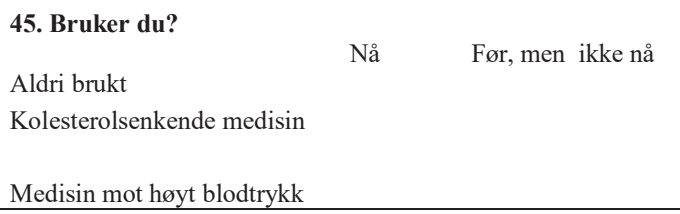 & $\begin{array}{l}\text { 45. Do you take? } \\
\text { Currently Previously } \\
\text { Lipid lowering drugs } \\
\text { Medications for high blood pressure }\end{array}$ \\
\hline b16_19 to b16_24 & $\begin{array}{l}\text { 46a. Har du i løpet av det siste året brukt noen av følgende } \\
\text { midler daglig eller nesten daglig? } \\
\text { Angi hvor mange måneder du brukte dem. Sett } 0 \text { hvis du ikke } \\
\text { har brukt noen av midlene. } \\
\text { Legemidler } \\
\text { Smertestillende } \\
\text { Sovemedisin } \\
\text { Beroligende midler } \\
\text { Midler mot depresjon } \\
\text { Allergimedisin } \\
\text { Astmamedisin } \\
\text { Med medisiner mener vi her medisiner som er kjøpt på apotek. } \\
\text { Kosttilskudd og vitaminer regnes ikke med. }\end{array}$ & 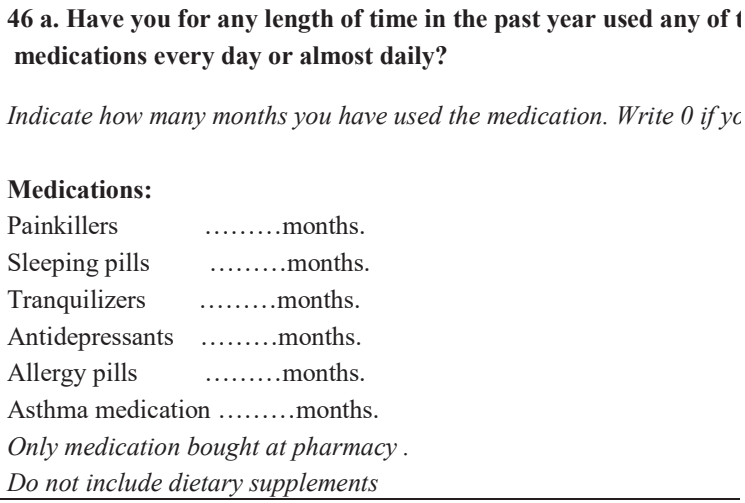 \\
\hline b16_3 to b16_8 & 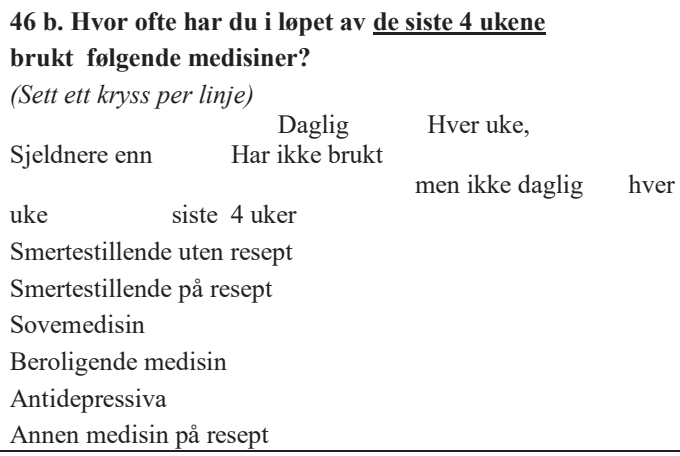 & 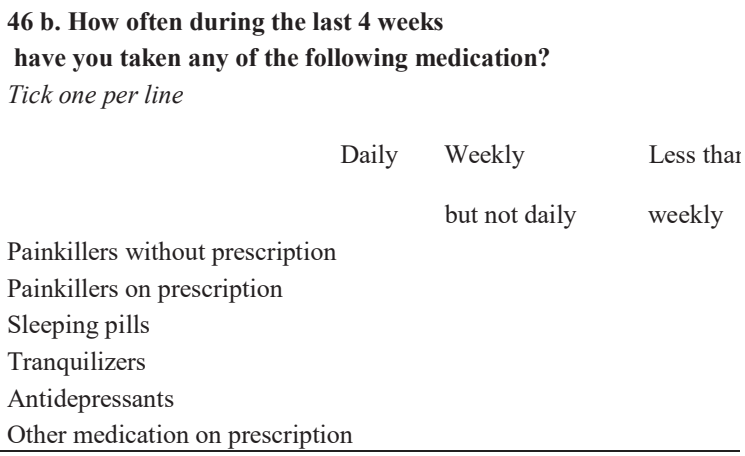 \\
\hline b16_9_1 to b16_18_3 & $\begin{array}{l}\text { 46c. Fyll inn navn på medisin, årsak til bruk og tiden den } \\
\text { ble brukt fra sp 46b } \\
\text { Navn på medisin } \quad \text { Grunn til bruk } \\
\text { lenge brukt } \\
\text { år/ett år eller mer } \\
1 . \\
2 . \\
3 . \\
4 . \\
5 . \\
6 .\end{array}$ & $\begin{array}{l}\text { 46.c Fill in name of medication, reason for use and time used from } \\
\text { Brand name Reason for use } \\
\text { For how long } \\
\text { up to } 1 \text { year/1 year or } 1\end{array}$ \\
\hline & KOSTTILSKUDD & DIETARY SUPPLEMENTS \\
\hline b16_25 to b16_27 & $\begin{array}{l}47 \text { a. Har du i løpet av det siste året brukt noen av følgende } \\
\text { midler } \\
\text { daglig eller nesten daglig? }\end{array}$ & $\begin{array}{l}47 \text { a. Have you for any length of time in the past year taken any of } \\
\text { following daily or almost daily? }\end{array}$ \\
\hline
\end{tabular}




\begin{tabular}{|c|c|c|}
\hline & \begin{tabular}{|l} 
Angi hvor mange måneder du brukte dem. Sett 0 hvis du ikke \\
har brukt noen av midlene. \\
Jerntabletter \\
Vitamin D-tilskudd \\
Andre vitamintilskudd
\end{tabular} & $\begin{array}{l}\text { Indicate how many months you have used them. Write } 0 \text { if you did no } \\
\text { Iron tablets } \\
\text { Vitamin D supplements } \\
\text { Other vitamin supplements } \\
\text { Cod liver oil }\end{array}$ \\
\hline b16_28, b16_29 & $\begin{array}{l}47 \text { b. Bruker du følgende kosttilskudd? } \\
\text { Ja, daglig } \\
\text { Nei } \\
\text { Tran, trankapsler, } \\
\text { Fiskeoljekapsler } \\
\text { Vitamin- og/eller } \\
\text { mineraltilskudd } \\
\end{array}$ & $\begin{array}{l}47 \text { b. Do you take any of the following? } \\
\text { Cod liver oil, capsules } \\
\text { Fish oil capsules } \\
\text { Vitamin and or } \\
\text { mineral supplements }\end{array}$ \\
\hline & $\begin{array}{l}\text { RESTEN AV SKJEMAET SKAL BARE BESVARES AV } \\
\text { KVINNER }\end{array}$ & THE REST OF THE FORM SHOULD ONLY BE FILLED IN B) \\
\hline b22 & $\begin{array}{l}\text { 48. Hvor gammel var du da du fikk menstruasjon første } \\
\text { gang? } \\
\text { ….......̊ar }\end{array}$ & $\begin{array}{l}\text { 48. How old were you when you started menstruating? } \\
\text {...........year }\end{array}$ \\
\hline b23 & $\begin{array}{l}\text { 49. Hvis du ikke lenger har menstruasjon, hvor gammel var } \\
\text { du da den sluttet? } \\
\text {..........år }\end{array}$ & $\begin{array}{l}\text { 49. If you no longer menstruate, how old were you when you stopp } \\
\text {...........year }\end{array}$ \\
\hline b24 & 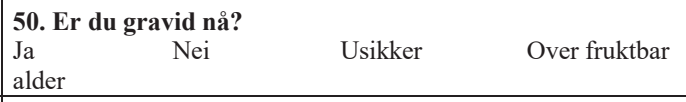 & 50. Are you pregnant at the moment? \\
\hline b25 & $\begin{array}{l}\text { 51. Hvor mange barn har du født tidligere? } \\
\text {...........barn }\end{array}$ & $\begin{array}{l}\text { Yes No Unsure } \quad \text { Postmenopausal } \\
\text { 51. How many children have you given birth to? } \\
\text {........children }\end{array}$ \\
\hline b26_1 to b26_12 & $\begin{array}{l}\text { 52. Hvis du har født, fyll ut for hvert barn barnets fødselsår } \\
\text { og omtrent antall } \\
\text { måneder du ammet hvert barn. } \\
\text { Barn Fødselsår } \\
\text { måneder med amming } \\
1 . \\
2 . \\
3 . \\
4 . \\
5 . \\
6 . \\
\end{array}$ & $\begin{array}{l}\text { 52. If you have given birth, what year was the child born and how } \\
\text { months did you breastfeed each child } \\
\text { Child Year born Number of months with breastfe } \\
1 . \\
2 . \\
3 . \\
4 . \\
5 . \\
6 .\end{array}$ \\
\hline b27_1 to b27_4 & $\begin{array}{l}\text { 53. Bruker du eller har du brukt: } \\
\text { Aldri } \\
\text { P-pille (også minipille) } \\
\text { P-sprøyte } \\
\text { Hormonspiral (ikke vanlig spiral) } \\
\text { Østrogen (tabletter eller plaster) } \\
\text { Østrogen (krem eller stikkpiller) } \\
\end{array}$ & $\begin{array}{l}\text { 53. Do you use or have you ever used: } \\
\text { Contraceptive pills (OC) (incl. minipill) } \\
\text { Contraceptive injections } \\
\text { Hormonal intrauterine device } \\
\text { Estrogen (tablets or patches) } \\
\text { Estrogen (cream or suppositories) }\end{array}$ \\
\hline b28_1to b28_5 & $\begin{array}{l}\text { 54. Hvis du brukte p-pille, minipille, p-sprøyte, } \\
\text { hormonspiral eller østrogen, } \\
\text { hvilket merke bruker du? }\end{array}$ & $\begin{array}{l}\text { 54. If you use contraceptive pills, hormonal intrauterine device, or } \\
\text { what brand do you currently use? }\end{array}$ \\
\hline
\end{tabular}


DEATH CERTIFICATE 



\section{Legeerklæring om dødsfall/melding om unaturlig dødsfall}

Jfr. lov om leger av $13 / 61980$ B $\$ 40$ og 41.
Blanketten fylles ut i samsvar med rettledningen på baksiden og leveres rekvirenten (den som har plikt til å melde dødsfallet) i forseglet konvolutt som i byene adresseres til skifteretten og på landet til lensmannen på dødsstedet. Kopi av legeerklæringen sendes den lokale politimyndighet, hvis dødsfallet kan være unaturlig. (Se rettledning på baksiden.)

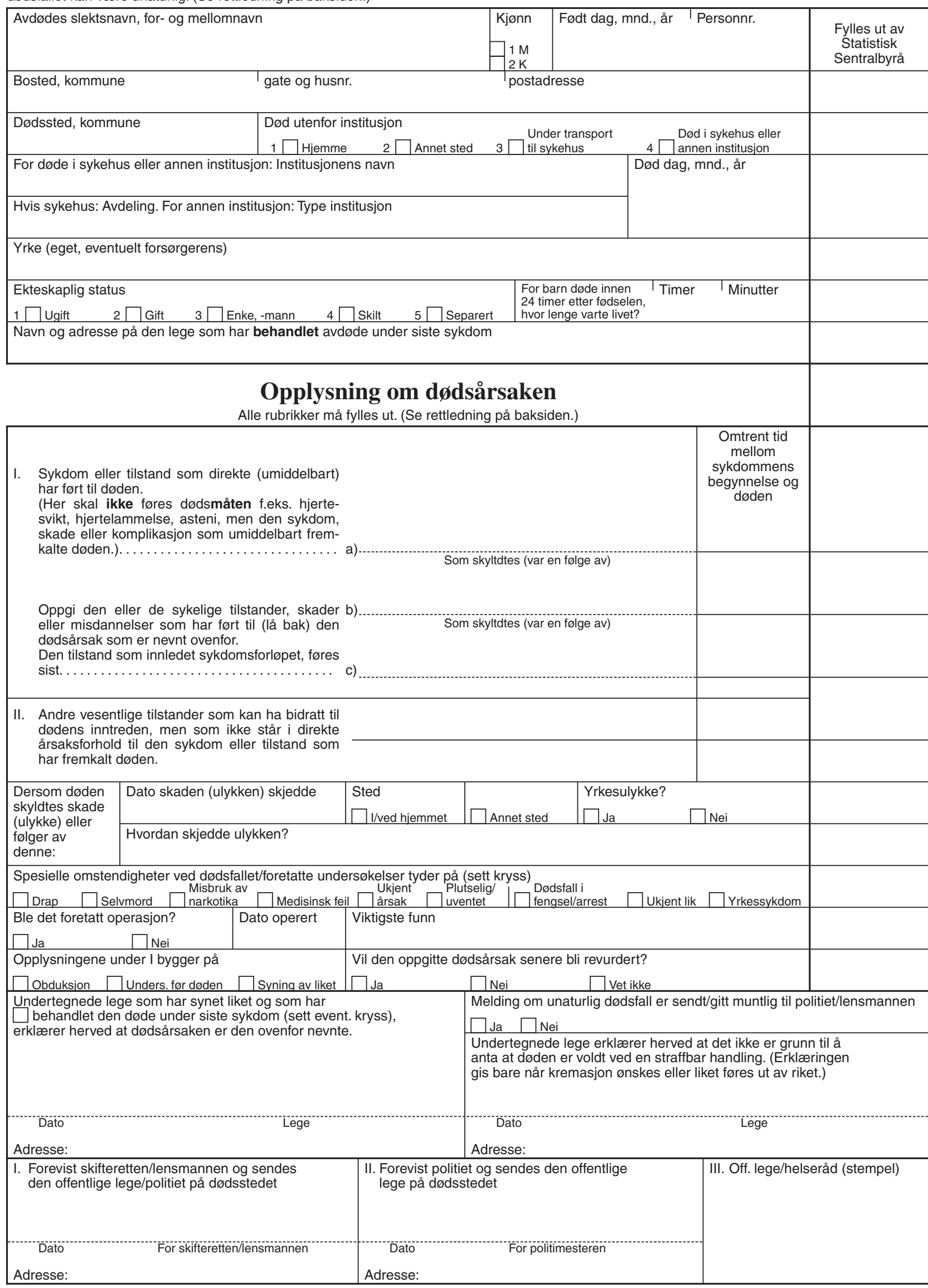




\section{Rettledning for legen ved utfylling av meldingen}

En dødsmelding er et dokument som har rettslig betydning. Alle opplysninger må derfor gis med største nøyaktighet, og meldingen mă fylles ut med tydelig skrift.

For de enkelte rubrikker må følgende iakttas:

Avdødes navn: Både slektsnavn, for- og mellomnavn skrives helt ut. For barn som dør før det har fått navn, oppgis foreldrenes (morens) slektsnavn.

Bosted: Her oppgir hvor den døde var registrert bosatt Personer som på grunn av utdanning eller arbeid midlertidig oppholder seg borte fra hjemmet, regnes som bosatt på hjemstedet. Personer som dør i sykehus, fengsel o.l., regnes som bosatt der de hadde sitt bosted før anbringelsen. For barn født på sykehus/klinikk, som dør umiddelbart etter fødselen, oppgis foreldrenes (morens) bosted. Personer som ved døden var anbragt i andre institusjoner (aldershjem, skolehjem o.1.) eller $i$ privat pleie, regnes som bosatt der. Norsk personell ved norske diplomatiske stasjoner i utlandet regnes forsatt som bosatt $\mathrm{i}$ den kommunen de hadde sitt bosted ved utreisen.

Dødssted: Her oppgis kommune, og det krysses av hvor døden inntrådte (hjemme, annet sted, under transport til sykehus, $i$ sykehus eller annen institusjon). Ved dødsfall $i$ sykehus oppgis sykehusets navn og avdeling, ved dødsfall i annen institusjon oppgis navn, type og postadresse.

Yrke: Oppgis avdødes yrke eller levevei. For yrkesaktive og tidligere yrkesaktive oppgis hovedyrket, for arbeidsløse vanlig yrke. For pensionister og trygdede oppgis tidligere yrke med tilføyelse «fhv». For forsørgede oppgis forsørgerens, eventuelt forsørgelsesmåten.
Dødsårsaken: (det vises også til særskilt rettledning)

Under Ia) skal føres den sykdom, komplikasjon eller tilstand som direkte fremkalte døden. I de fleste tilfelle vil denne umiddelbare dødsårsak skyldes eller være en følge av en eller flere sykdommer, skader eller tilstander. Disse føres under b) og c), og den tilstand som etter legens mening startet årsakskjeden føres sist. Hvis den sykdom eller tilstand som føres opp under Ia) beskriver hendelsesforløpet fullstendig, er det ikke nødvendig å fylle ut b) og c).

Årsakssammenhengen mellom Ia, b og c omfatter ikke bare den etiologiske eller patogenetiske sammenheng, men også sekvenser der grunnlidelsen antas å ha ført til den direkte dødsårsak p.g.a. funksjonsnedsettelse eller andre forstyrrelser.

Under II føres andre vesentlige tilstander som bidro til den dødelige utgang, men som ikke sto i direkte årsaksforhold til den sykdom eller tilstand som fremkalte døden.

Hvis mulig oppgis om tilstanden var akutt eller kronisk og hvor lenge hver tilstand har vart. Ved sykdomsbetegnelser hvor lokalisasjon ikke går fram av sykdommens navn, eks. ved kreft og tuberkulose, må sykdommens anatomiske sete oppgis.

Ved unaturlig død skal legen opplyse om det foreligger drap, selvmord eller ulykke. Utførlige opplysninger om den ytre årsak bes gitt uansett om døden er en umiddelbar følge av skaden eller av den patologiske tilstand som skaden kan ha ført til.

Ved unaturlig død skal legen sende skriftlig melding til politiet/lensmannen på dødsstedet, jfr. § 41 i lov om leger av $13 / 61980 \mathrm{nr}$. $42 \mathrm{og}$ forskrifter for legens melding om unaturlig dødsfall o.1. Se forøvrig særskilt rettledning nedenfor.

\section{Rettledning for legen ved melding om unaturlig dødsfall}

Legeloven $\S 41$ bestemmer at den lege som skal gi erklæring om dødsfall, uten opphold skal underrette politiet dersom det er grunn til å regne med at dødsfallet kan være unaturlig. Pă samme måte meldes funn av ukjent lik, og dødsfall i fengsel eller i politi- eller militærarrest. Unnlatelse av å melde fra er straffbar. Meldeplikten går foran taushetsplikt.

Melding til politiet om unaturlig dødsfall skal først skje muntlig eller telefonisk så snart som mulig. Deretter skal sendes skriftlig melding. Denne er en kopi av legeerklæringen om dødsfall, for at legene skal slippe et ekstra meldingsskjema. På skjemaet er det en del spørsmål som knytter seg til unaturlig dødsfall. Opplysningene her hører med til den vanlige legeerklæring om dødsfall.

Grensen mellom naturlig og unaturlig død er ikke sparp. Det kan ofte være uklart om et dødsfall er naturlig eller unaturlig. Årsaksforholdene er ofte usikre, og kan hyppig bare bringes på det rene ved etterforskning eller ved sakkyndig likundersøkelse.
Legen behører ikke ta et bestemt standpunkt til om det foreligger naturlig eller unaturlig død, til årsaks- eller skyldforhold e.l. Hans plikt til à gi muntlig melding til politiet inntrer når han skjønner at det kan foreligge unaturlig død. Når han så gir skriflig melding, kan legen gi uttrykk for at svaret er usikkert ved å sette spørsmålstegn istedenfor kryss ved de spørsmål som gjelder unaturlig død eller ved å krysse av i rubrikken for ukjent årsak. Et dødfall vil kunne falle inn under flere rubrikker; et narkotikadødsfall kan samtidig være et selvmord, en ulykke eller et uaktsomt drap, og det kan inntreffe under anholdelse eller i arrestrom.

Har legen gitt muntlig melding, bør i alle tilfeller skriftlig melding sendes, også om dødsfallet ikke lenger antas å være unaturlig.

\section{Oversendelse av dødsmeldinger}

Ved begravelse skal skifteretten (lensmannen) etter å ha fylt ut skjema for melding til soknepresten, (jfr. Justisdepartementets rundskriv av 1 . desember 1938) sende denne legeerklæring direkte (i posten) til den offentlige lege på dødsstedet.

Ved kremasjon eller hvis liket skal føres ut av riket, skal skifteretten (lensmannen) etter å ha fylt ut skjema for melding til soknepresten (jfr. Justisdepartementets rundskriv av 1. desember 1938) oppfordre rekvirenten til å bringe legeerklæringen videre til politiet, som gir ham (henne) særskilt erklæring om at det fra politiets side ikke er noe til hinder for kremasjon eller at liket føres ut av riket.

Politiet sender deretter legeerklæringen direkte (i posten) til den offentlige lege på dødsstedet.
Den offentlige lege skal sende de dødsmeldingene han mottar til Statistisk Sentralbyrå, postboks 8131 Dep., Oslo. Fra byene skal meldingene sendes den 1. i hver măned, fra landdistriktene kvartalsvis innen 8 dager etter kvartalets utløp (jfr. årlig rundskriv fra Helsedirektøren).

Denne blankett fås ved henvendelse til den offentlige lege, som får det nødvendige antall fra fylkeslegen. Fylkeslegen rekvirerer skjema fra Sosial- og helsedirektoratet, postboks 7000 St. Olavs plass, 0130 OSLO.

Leveringsadresse: Universitets gt. 2 
ERRATA

LIST OF CORRECTIONS 



\section{ERRATA}

Regarding paper I, "Offspring birth weight and cardiovascular mortality among parents: the role of cardiovascular risk factors".

The number of offspring excluded with < 37 weeks $(172,546)$, > 44 weeks $(132,228)$ and < $100 \mathrm{~g}$ (212) in the flow chart was incorrect.

The correct number of the offspring excluded were: $<37$ weeks $(154,674),>44$ weeks $(137,075)$ and $<1000 \mathrm{~g}(7,481)$.

Page 31: The flow chart of paper I (with corrections). 
